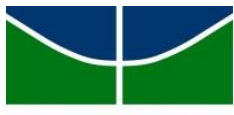

\title{
UnB
}

Universidade de Brasília Instituto de Letras

Departamento de Linguística, Português e Línguas Clássicas

Programa de Pós-Graduação em Linguística

ASPECTOS MORFOSSINTÁTICOS DO PORTUGUÊS FALADO NO QUILOMBO SIRICARI/MARAJÓ: UMA PERSPECTIVA AFRO-INDÍGENA

Cristiane Torido Serra

Orientadora: Prof ${ }^{a}$. Dr ${ }^{a}$. Walkíria Neiva Praça

Brasília

2016 


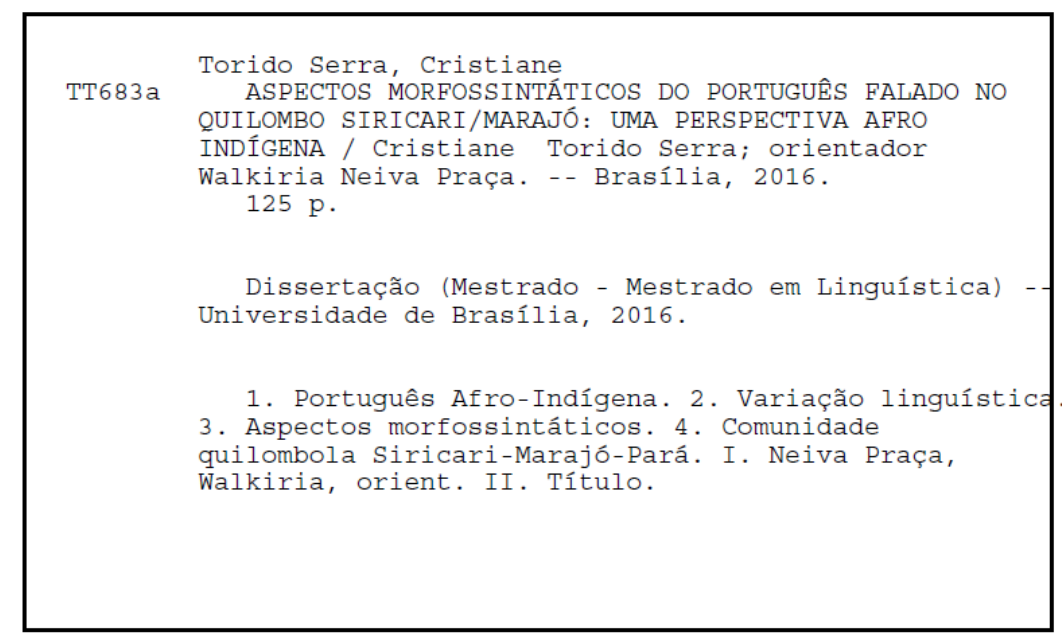




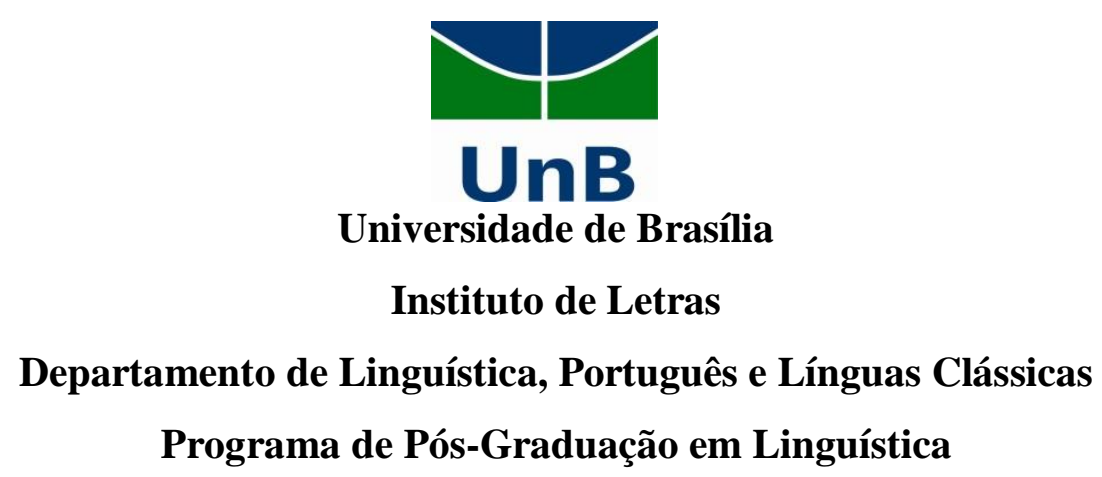

Programa de Pós-Graduação em Linguística

\section{ASPECTOS MORFOSSINTÁTICOS DO PORTUGUÊS FALADO NO QUILOMBO SIRICARI/MARAJÓ: UMA PERSPECTIVA AFRO-INDÍGENA}

Cristiane Torido Serra

Dissertação apresentada ao Departamento de Linguística, Português e Línguas Clássicas da Universidade de Brasília como parte dos requisitos para a obtenção de título de Mestre em Linguística.

Brasília

2016 


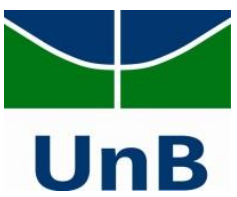

Universidade de Brasília

Instituto de Letras

Departamento de Linguística, Português e Línguas Clássicas

Programa de Pós-Graduação em Linguística

DISSERTAÇ̃̃O DE MESTRADO

\section{ASPECTOS MORFOSSINTÁTICOS DO PORTUGUÊS FALADO NO \\ QUILOMBO SIRICARI/MARAJÓ: UMA PERSPECTIVA AFRO-INDÍGENA}

Cristiane Torido Serra

Orientadora: Prof ${ }^{a}$. Dr ${ }^{\mathrm{a}}$. Walkíria Neiva Praça

Banca examinadora:

Prof $^{a}$. Dra ${ }^{a}$ Walkíria Neiva Praça $(U n B)$

Prof. Dr. Dioney Moreira Gomes (UnB)

Prof $^{\mathrm{a}}$. Dra . Aline da Cruz (UFG)

Prof. Dr. Marcus Lunguinho (UnB) Suplente 
Para os quilombolas de Salvaterra que ainda lutam por seus direitos e reconhecimento social. 


\section{AGRADECIMENTOS}

À Deus o agradecimento primeiro, porque é Dele que trago a perseverança para alcançar meus ideais, é Dele que nascem as oportunidades que encontro, e é a partir Dele que conheci todas as queridas pessoas que me acompanharam nesta experiência ímpar.

À comunidade Siricari, por expor suas vidas a mim, pessoa desconhecida que sempre era recebida com sorriso de boas-vindas e confiança pelo meu trabalho. Agradeço pelas horas de gravação, pelas aulas de extrativismo no 'quintal' de casa, pelos sabores experimentados, pela simplicidade de vida e beleza nativa que jamais esquecerei.

Às comunidades de Mangueiras, Deus Ajude, Providência e Salvá, pela acolhida.

Ao Evandro, companheiro de estradas quilombolas, pelas histórias marajoaras e garantia de meu trajeto em Marajó.

À meu filho Bruno, maior incentivador deste estudo, dedico à ele essa conquista.

À meu filho Rafael, pelos muitos abraços e carinhos em troca de minhas constantes ausências.

Às queridas Ignez, Ana Paula e Ellen pelo incentivo e apoio incondicional.

A Prof ${ }^{\mathrm{a}}$. Dr ${ }^{\mathrm{a}}$. Walkíria Neiva Praça, por fomentar em mim o profundo interesse pela investigação do Português Afro-Indígena, algo que jamais pensava estudar. Mas, muito além disso, por guiar meus caminhos, permitindo que eu sentisse a pesquisa científica em sua essência nas visitas à campo, por deixar-me enxergar nas transcrições a riqueza linguística presente nos dados, por conduzir-me aos primeiros ensaios textuais, às primeiras exposições científicas. Agradeço a compreensão, as alegrias e dores que me fizeram crescer, e a amizade sincera que se fundiu nestes poucos anos que nos conhecemos.

À Prof ${ }^{\mathrm{a}}$. Dr ${ }^{\mathrm{a}}$. Márcia Santos Duarte de Oliveira, pelo incentivo que me levou em direção ao tema Português Afro-Indígena, pelas leituras enviadas, pelas orientações em manejo com os dados, e pelo carinhoso atendimento em sua casa. 
À Prof ${ }^{\mathrm{a}}$. Dr ${ }^{\mathrm{a}}$. Aline da Cruz, pelas leituras iniciais deste estudo, sugestões, comentários, bibliografias e incentivo sincero quando ainda pouco se tinha de novidades.

Ao Prof. Dr. Dioney Moreira Gomes, membro da banca de qualificação, pela leitura cuidadosa, observações e sugestões.

Aos docentes da UnB, especialmente aos Profs. Dra . Marina Magalhães e Dr. Marcus Lunguinho, pelo exemplo de dedicação, competência, organização e seriedade acadêmica, e Prof ${ }^{\mathrm{a}}$. Dra. Maria Luiza Monteiro Sales Corôa, pelos esclarecimentos decisivos.

Ao Prof. Dr. Allan Norman Baxter que, antes de conhecê-lo pessoalmente, era o vetor que seguia para o estudo do contato linguístico. Agradeço o interesse por este trabalho, artigos enviados e incentivo que me levou a buscar novas informações, novas bibliografias e apaixonar-me por esse campo da linguística.

A Prof ${ }^{\text {a. }}$ Dr ${ }^{\mathrm{a}}$. Ângela França, pelos e-mails de feedback e indicação bibliográfica.

Agradeço aos colegas de mestrado que, direta ou indiretamente sempre estiveram apoiando este estudo.

Ao $\mathrm{CNPq}$, pela bolsa de mestrado que permitiu a realização de viagens e a estadia em Marajó.

Importa acrescentar que as falhas, omissões e/ou equívocos ocorridos neste estudo são de minha inteira responsabilidade. 
Que quer dizer Marajó? (m-bará-yó) é o tirado do mar e também o tapa mar. Mbará pode variar em mará e pará. E assim temos Pará o mar. Batista Caetano vai mais longe nos diz que pará deriva de y-párá: as águas colhe, o colecionador das águas.

Marajó é dédalo de igarapés (igará-apé: caminho da canoa). Canoa é y-g-yara, dona da água, superior à água. Igapó (yg-apó) a água que invade.

Pe. Giovanni Gallo (1997:108) 
Torido Serra, Cristiane. Aspetos morfossintáticos do português falado no quilombo Siricari/Marajó: uma perspectiva afro-indígena. Dissertação de mestrado. Programa de Pós-Graduação em Linguística da Universidade de Brasília - PPGL/UnB. Brasília, 2016.

\section{RESUMO}

Esta dissertação tem por objetivo apresentar variações do português falado na comunidade quilombola Siricari com destaque nos aspectos morfossintáticos. A comunidade se autodenomina quilombola e reconhece sua descendência em estratos africanos e indígenas. Segundo Oliveira et alii (2015:08) o Português Afro-Indígena consiste de uma variedade vernacular rural do português brasileiro $\mathrm{L}_{1}$ falada por comunidades envoltas em miscigenação afro-indígena e que selecionam politicamente o termo "afro" ou "indígena". Diante desse pressuposto, tratamos neste estudo de variações do português brasileiro que sugerem forte relação com a proposta defendida com Português Afro-Indígena. O trabalho compõe-se de três capítulos. O capítulo 1 é destinado à comunidade Siricari e seus aspectos etnográficos, bem como contextualiza historicamente a região de Salvaterra e Marajó do qual a comunidade é parte. O capítulo 2 discorre sobre a etnolinguística, abrangendo a perspectiva da variação linguística à luz da proposta do Português Afro-Indígena. O capítulo 3 dedica-se à descrição dos aspectos morfossintáticos característicos da comunidade quilombola, bem como revela a presença de traços [+ marcados] típicos de uma variação considerada pela literatura como Português Afro-Indígena.

Palavras-chave: Variação Linguística; Aspectos morfossintáticos; Português AfroIndígena; Quilombo Siricari. 


\begin{abstract}
This thesis aims to present variations of spoken Portuguese in the quilombola community of Siricari, mainly in morphosyntactic aspects. The community calls itself quilombola and recognizes their ancestry in African and indigenous strata. According to Oliveira et alii (2015: 08), Afro-Indigenous Portuguese consists of a rural vernacular variety of Brazilian Portuguese $\mathrm{L}_{1}$ spoken by communities shrouded in africanindigenous miscegenation and communities who politically choose the term "african" or "indigenous". Faced with these premises, in this study we address the changes in Brazilian Portuguese that suggest a strong relationship with the proposal defended by the African-Indigenous Portuguese line of research. This work consists of three chapters. Chapter 1 describes the Siricari community and its ethnographic aspects, as well as it historically contextualizes the Salvaterra and Marajó regions in which the community is located. Chapter 2 discusses the Ethnolinguistics, including the perspective of linguistic variation regarding the proposal of the African-Indigenous Portuguese line of research. Chapter 3 provides a description of the morphosyntactic aspects which are characteristic of the quilombola, and reveals the presence of traces [+ marked] which are typical of variation considered by the literature as AfricanIndigenous Portuguese.
\end{abstract}

Keywords: Linguistic Variation; Morphosyntactic Aspects, African-Indigenous Portuguese; Quilombo Siricari 


\section{LISTA DE FIGURAS, QUADROS, MAPAS E GRÁFICO}

Figura 1 - Urna funerária marajoara 1000-1250 d.C. ..............................................xiv

Figura 2 - Ruínas da Igreja de Nossa Senhora do Rosário em Joanes - Marajó.............. 13

Figura 3 - Igreja N. Senhora do Rosário (reconstrução) ............................................ 42

Figura 4 - Travessia de acesso para comunidades remanescentes quilombolas .............59

Quadro 1- Composição do corpus do português falado na comunidade Siricari -

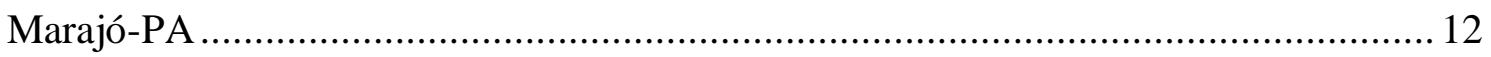

Figura 2 - Continuum dialetal do português falado no Brasil ....................................56

Mapa 1- Localidades quilombolas em Salvaterra - Marajó - PA................................ 15

Mapa 2- Território de pesca das comunidades quilombolas ...................................... 17

Mapa 3 - Mesorregião Geográfica do Marajó ............................................................28

Gráfico 1- Índice populacional de 12 comunidades quilombolas de Salvaterra .............34

Gráfico 2: Variedades morfossintáticas do português falado nas comunidades Siricari,

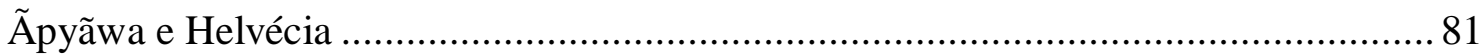




\section{SUMÁRIO}

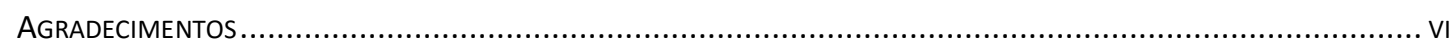

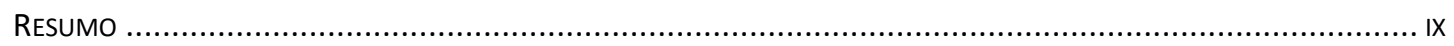

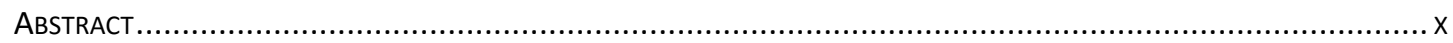

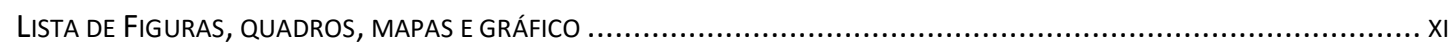

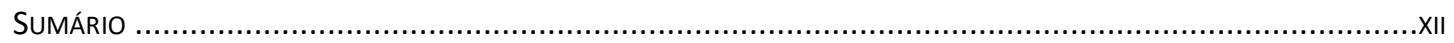

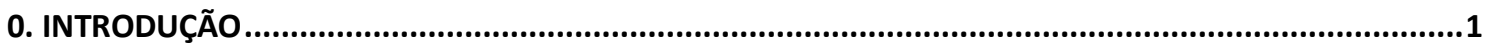

0.1. PONTOS DE PARTIDA: A TEMÁTICA AfRO-INDÍGENA E A ESCOLHA DA COMUNIDADE ......................................

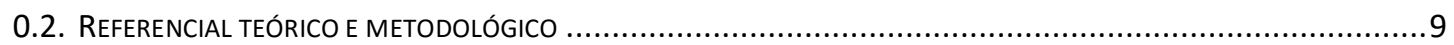

CAPÍTULO 1: A COMUNIDADE SIRICARI E UM BREVE HISTÓRICO DA CONSTITUIÇÃO ÉTNICA NA ILHA DE

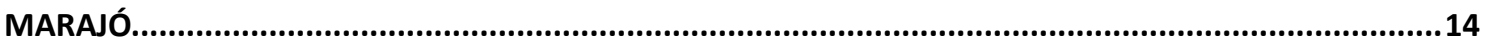

1.1. A COMUNIDADE QUILOMBOLA SIRICARI-MARAJÓ ...................................................................... 14

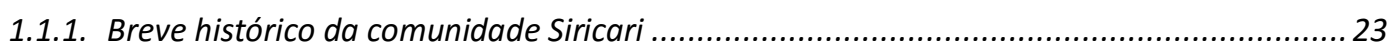

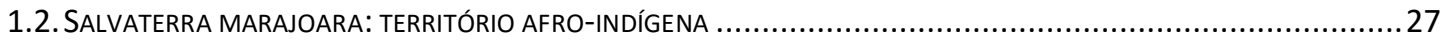

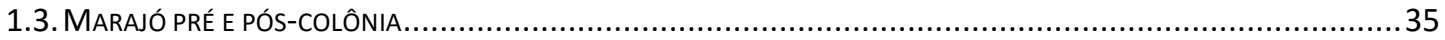

CAPÍTULO 2: A ETNOLINGUÍSTICA E O PORTUGUÊS AFRO-INDÍGENA................................................43

2.1 ReMANESCENTE DE CONTATO LINGUístICO ............................................................................ 43

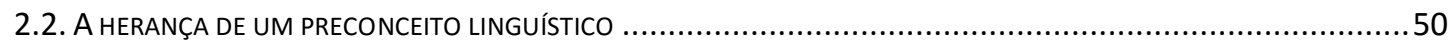

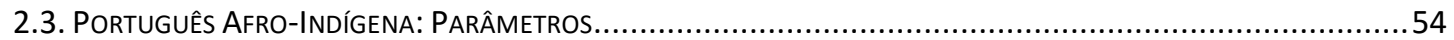

CAPÍTULO 3: MORFOSSINTAXE DO PORTUGUÊS FALADO EM SIRICARI: DESCRIÇÃO E ANÁLISE ...........60

3.1. ASPECTOS MORFOSSINTÁTICOS DO PORTUGUÊS FALADO EM SIRICARI......................................................60

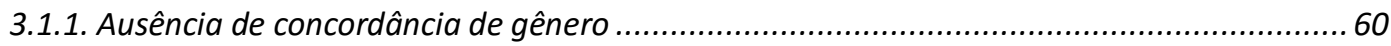

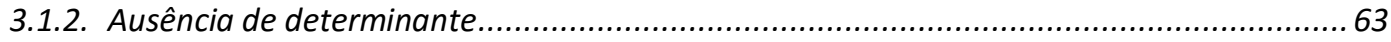

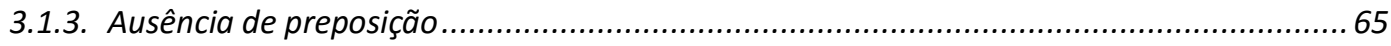

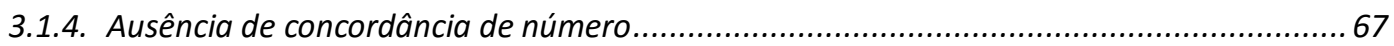

3.1.5. Ausência de cópula e outras supressões verbais........................................................ 68

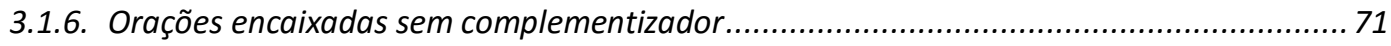

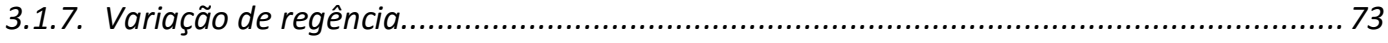

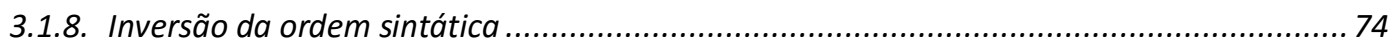

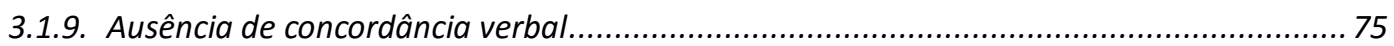

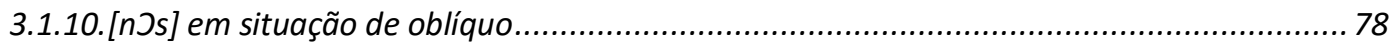

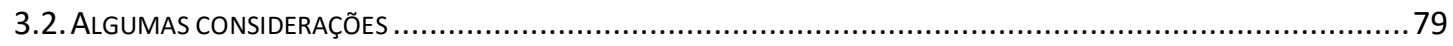

3.3. ALTERNÂNCIA VOCÁLICA < U:O > E < I:E > ENTRE 1a E 3a PESSOAS DO SINGULAR ......................................82

3.3.1. Alternância vocálica $<$ i:e $>$ das formas verbais tive:teve .......................................... 83 
3.3.2. Alternância vocálica <i:e > das formas verbais fiz:fez

3.3.3. Alternância vocálica $<$ u:o $>$ das formas verbais fui:foi ......................................... 87

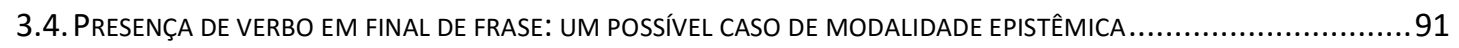

3.4.1. Modalidade epistêmica do verbo ser em final de frase ............................................... 91

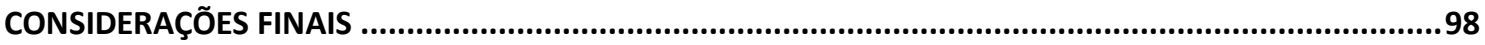

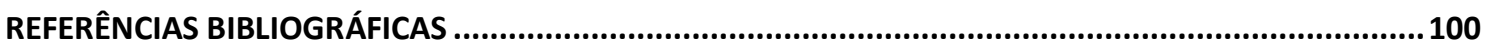




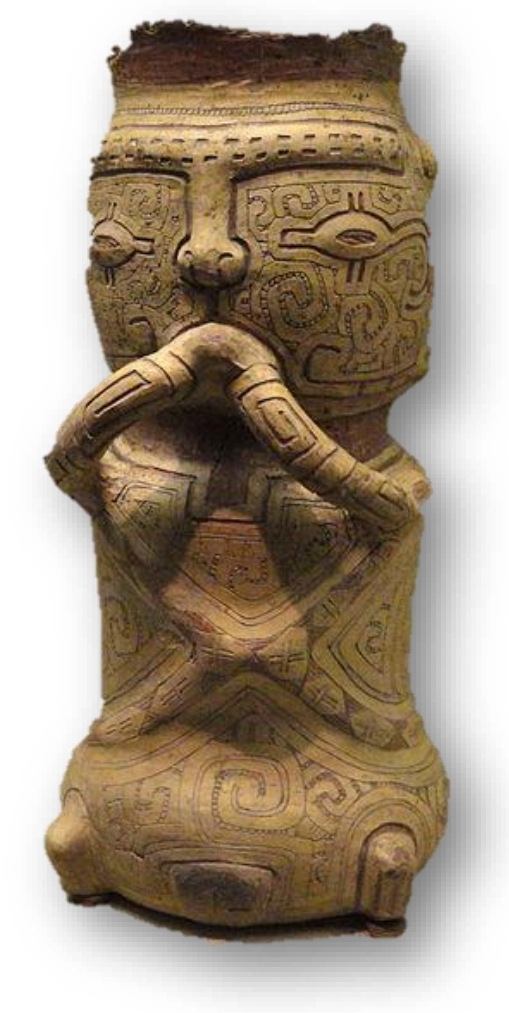

Figura 1 - Urna funerária marajoara 1000-1250 d.C. Museu Americano de História Natural

Que língua nós apagamos para termos uma língua nacional (o português)? De que língua (ou línguas) foi preciso nos distanciar historicamente e quais as línguas que tiveram de ser silenciadas para que obtivéssemos uma língua portuguesa?

Orlandi, apud Freire, 1971:63 


\section{INTRODUÇÃo}

Este trabalho propõe descrever aspectos morfossintáticos do português falado na comunidade quilombola Siricari, situada na região de Salvaterra, ilha de Marajó, Pará. Registros históricos da região de Marajó direcionam este estudo a culturas africanas e indígenas, num esforço de resgatar conexões do passado a fim de compreender o português falado hoje naquela comunidade.

\subsection{Pontos de partida: a temática Afro-Indígena e a escolha da comunidade}

Investigar aspectos gramaticais do português falado em comunidades rurais amazônicas significa reconhecer, diante dos estratos étnico e social, a proeminência do contato da língua portuguesa e das línguas indígenas e africanas. É evidente o argumento de que a heterogeneidade étnica desta região se compôs da mistura entre o branco, o índio e o negro, o que "resulta hoje o tipo étnico amazônico" (cf. Salles, 1971:135). Entretanto, apesar da inegável miscigenação, a língua que se manteve ativa na trajetória de comunicação interétnica na Amazônia colonial foi a Língua Geral Amazônica (doravante LGA), e não o português trazido pelo colonizador.

O termo Língua Geral Amazônica surgiu no período de colonização portuguesa no Maranhão, Pará e Amazônia na primeira metade do século XVII. Segundo Rodrigues (1996:9-10), essa região era habitada por tupinambás e, como resultado do contato com portugueses, espanhóis e franceses, especialmente no período de ocupação da Ilha de São Luis ${ }^{1}$ e terras vizinhas (1611-1614), consolidou-se a língua tupinambá como língua de comunicação interétnica.

Apesar de ter sido tratada como a língua de contato, a princípio transitória, a LGA se fortaleceu ao longo do período colonial, chegando a ser reconhecida como língua oficial do Estado do Maranhão e Grão-Pará em 1689, conforme trata a Carta Régia de 30 de novembro daquele ano ( $c f$. Bessa Freire, 2004:61). Seu declínio surge

\footnotetext{
${ }^{1}$ Ilha de São Luís situa-se no Estado do Maranhão. Sua antiga denominação indígena Upaon-Açu foi dada pelos tupinambás e significa "ilha grande". É nela que está localizada a maior parte da área de São Luís, a capital do estado do Maranhão. Estão localizadas na ilha além de São Luís, Paço do Lumiar, São José de Ribamar e parte da Raposa.
} 
com a imposição de um monolinguíssimo português na região Amazônica e ganha força quando Grão-Pará e Maranhão aderem à independência do Brasil em 1823.

A língua geral amazônica falada até meados do século XIX pelos brancos, negros e índios produziu marcas significativas na língua que se consagraria como "português brasileiro". A herança linguística contraída pela relação de contato permanente com as várias línguas advindas da região amazônica revela-se, sobretudo, em dialetos de comunidades rurais. Alguns aspectos linguísticos podem referir-se à língua de substrato e são observados como um tipo de variação do português vernacular brasileiro ou, conforme dispõe Mattoso Câmara acerca do funcionamento $\mathrm{e}$ empréstimos fonéticos na língua portuguesa (1975:57).

$[\mathrm{N}] \mathrm{o}$ português do Brasil, não há fonema tupi ou de outra origem indígena, ou, ainda, de origem africana. [Mas], não há como negar [...] que a língua de susperestrato, adstrato ou substrato pode determinar certos itens lexicais [...] que, sem isso, não eram de se esperar. [...] é [...] possível que a eliminação dialetal de / $1 /$ intervocálico, no Brasil, com a redução a /y/ consonântico (foia, em vez de folha, oio em vez de olho, etc.) se explique pelo português crioulo dos escravos negros ou pelo substrato indígena, visto que nas línguas indígenas não há oposição /1/-/r/ e /1/ como /l/, podem ter sido isso mal interpretados. ${ }^{2}$.

É razoável considerar que desdobramentos linguísticos no dialeto do português brasileiro provenham de substratos de base indígena, africana, bem como de traços de um português arcaico. O que nos mostra Oliveira et alii (apud Cecim, 2014:21) é que "coexiste uma variedade do português brasileiro falada por comunidades de fala aquilombadas". Para esses autores, é possível que na fala de cada comunidade dita como 'aquilombada', estejam eles em 'terras de preto', 'terras indígenas' ou 'terras mistas ${ }^{3}$ existam marcas específicas podendo ser consideradas como uma variedade vernacular do português brasileiro.

\footnotetext{
${ }^{2} \mathrm{Cf}$. IPA, / $/$ / para a consoante lateral palatal. Não se respeitaram os parágrafos na citação.

3 'terras de preto': uma descendência de africanos; 'terras indígenas': etnias que perderam ou estão por perder por completo suas línguas maternas, mas mantém seus laços identitários; 'terras mistas';
} 
Com o propósito de ampliar a discussão sobre as variantes do português vernacular brasileiro, este estudo toma a direção do Português Afro-Indígena, o qual se projeta para os falares de comunidades rurais que trazem em sua história traços de miscigenação africana e indígena.

A temática do Português Afro-Indígena defendida por Oliveira \& Praça (2013) foi o impulso norteador para o desenvolvimento dessa pesquisa. Aliado a isso, a carência de estudos linguísticos acerca dessa temática e a herança étnica africana e indígena na região norte do Brasil determinaram a escolha da região amazônica de Marajó $^{4}$. A abrangência de remanescentes de quilombo na região de Marajó em meio a um cenário tipicamente indígena indicou-nos, antes de tudo, o caráter etnolinguístico que a pesquisa assumiria.

As primeiras preocupações se concentraram nas características étnicas de descendência africana e indígena que constituiriam a comunidade. Para nos auxiliar nessa busca, fizemos contato com a Associação de Quilombos do Pará - Malungo ${ }^{5}$, instalada em Belém. Chegamos ao coordenador dos remanescentes de quilombos do município de Salvaterra, em Marajó, o qual nos conduziu a algumas comunidades como avaliação preliminar.

Visitamos cinco comunidades reconhecidas pela Fundação Palmares como remanescente de quilombo, entre elas: Siricari, Providência, Deus Ajude, Mangueiras e Salvá. Embora todas elas tenham nos mostrado traços de evidente constituição africana e indígena, optamos pela comunidade Siricari pela particularidade de seu nome sugerir procedência indígena e ser topônimo de um quilombo. Contudo, não faltou a vontade de incluir todas as comunidades neste mesmo projeto.

comunidades aquilombadas no norte do Brasil cuja formação ética é negra e indígena. Termos e significados cunhados por Oliveira et al (2015) ao conceituar português afro-indígena.

${ }^{4} \mathrm{O}$ espanhol Vicente Pizón a batizou de Ilha Grande de Joannes, teve seu primeiro nome como Ilha dos Nheengaíbas, por haver ali "línguas dificultosas as muitas cabildas gentílicas que nela tinham habitáculo", somente recebeu o nome de Marajó em 1754, que em tupi significa "barreira do mar". (Ver Plano de Desenvolvimento Territorial Sustentável para o Arquipélago do Marajó, págs. 12 e 17-18; Ensaio Corográfico sobre a província do Grão-Pará, p. 270)

${ }^{5}$ Entidade designada como Coordenação Estadual das Associações das Comunidades Remanescentes de Quilombo do Pará. 
Os primeiros contatos foram feitos com a família Figueiredo por conter ali os herdeiros mais antigos e, também, por ser a residência do presidente da comunidade Siricari. Recebemos autorização deste representante para entrarmos na comunidade, o qual nos foi, também, muito solícito na condução das demais moradias durante todo o período deste estudo. Fomos recebidas com interesse pelos demais moradores que viam na investigação a possibilidade de registro sobre a história da comunidade, pois alegavam que muitas informações daquele lugar se perderam com o tempo e hoje não mais se esclareciam.

Logo nos primeiros contatos verificamos comumente a relação de miscigenação étnica africana e indígena nas famílias da comunidade Siricari. Esse aspecto é confirmado ao retomarmos estatísticas e fatos históricos referentes à composição social da região de Marajó. Salles (1971), Freire (2004, 2003), Baena (2004), Pacheco (2010, 2011) entre outros estudiosos trazem evidências de agrupamentos e casamentos entre estas etnias ainda no período colonial.

Exemplo disso é o que nos revela Pacheco (2011:45) sobre a perspectiva de contato e empréstimos etnolinguísticos, sociais ou culturais em Marajó de que ali se "desvelam espaços inter-relacionais de culturas díspares". O autor aponta para a construção de uma identidade afro-indígena no corredor da Amazônia ${ }^{6}$ com base em estudos de Salles (1971:51)

Nações indígenas Aruans, Cajuais, Marauanás, Sacacas, Caias, Araris, Anajás, Muanás, Mapuás, Mamaianases, Chapounas, Pacajás, dentre inúmeras outras, erigiram por campos, rios e florestas "zonas de contato" com nações africanas de Angola, Congo, Guiné, Benguela, Cabinda, Moçambique, Moxincongo, Mauá ou Macuá, Caçanje, Calabar ou Carabá, de origem banto, e Mina, Fãnti-Achânti, Mali ou Maí ou Mandinga, Fula, Fulope ou Fulupo, Bijogó ou Bixagô, de origem sudanesa, além de indicações duvidosas como Bareua ou Barana, Lalu ou Lalor, Pabana ou Babana.

Nas palavras do historiador José Honório Rodrigues (1983:33) "à Babel de línguas indígenas a que referiu Antônio Vieira, se une outra Babel de línguas africanas”.

\footnotetext{
${ }^{6}$ Expressão cunhada por Pacheco (2011) ao referir-se a ambientes de interações afro-indígenas.
} 
Nesse cenário de multilíngue colonial, vale a pena relatar um dos primeiros estudos sobre línguas e dialetos africanos no Brasil, Os Africanos no Brasil, de Nina Rodrigues ${ }^{7}$ (1932:187). O autor mostra que os negros adotaram uma língua africana como língua geral negra, uma vez que de tão numerosos eram os dialetos africanos no Brasil, "poderiam dizer equivalentes em numero ao dos carregamentos de escravos lançados no paiz". Ele afirma que entre a infinita multiplicidade e matizes dialetais africanos "tornou-se uma necessidade imperiosa para os escravos negros adoptar uma língua africana como língua geral, em que todos se entendessem". Ainda o mesmo autor afirma que duas línguas tivessem servido de língua geral negra: o nagô ou ioruba na Bahia, e o quimbundo ou congoesa no norte e sul.

A língua nagô é, de fato, muito falada na Bahia, seja por quase todos os velhos africanos das diferentes nacionalidades, seja por grande numero de crioulos e mulatos. [...] Tem havido nesta cidade inscripções em língua nagô em casas de commercio de negros, como em templos ou pêgis fetichistas. [...] Quando em 1899 estiveram nesta cidade os missionários catholicos que percorriam o Brasil angariando donativo para a catechese africana, foram eles aconselhados a dirigirse á população de côr da cidade em língua nagô. (Rodrigues, 1932: 200-201)

[...] não se encontra em parte alguma, nos autores pátrios, a menção da língua bantú especial que serviu de língua geral. [...] Todavia, acreditamos que o kimbundo ou língua d'Angola, cuja estrutura fundamental se conserva a mesma desde o século XVII, tal como a conhecemos pelos trabalhos dos jesuítas Pedro Dias (Arte da língua d'Angola, 1697) e Francisco Porcanio (Gentiles Angola in fidie Mysteriis eruditus, 1643). (Rodrigues, 1932:229)

Conforme Petter (2006) o quimbundo é uma língua africana plena que foi transplantada para o norte do Brasil no período colonial. Cogita-se ter sido a língua

7 Nina Rodrigues dedicou os últimos 15 anos de sua vida (1890 a 1906) ao estudo dos "últimos africanos" no Brasil, revelando amplo interesse pela influência das línguas africanas no falar brasileiro. A obra traz material etnográfico e linguístico, assinalando a procedência africana, tipos linguísticos introduzidos no Brasil colonial, religião, mitologia e culto africano. 
falada na República dos Palmares (1930), um dos mais importantes quilombos do período colonial brasileiro (Pernambuco), destruído em 1695. Apesar de haver controvérsias sobre a língua que se falava em Palmares (Reis \& Gomes, 2011:49), “os palmarinos, como uma população de origem variada, congregando africanos de diferentes tribos, índios e europeus, deviam usar uma espécie de língua comum, não necessariamente com base no banto".

Apesar da possibilidade da mescla cultural em Palmares, em referência aos movimentos de negros anteriores ao século XIX, Nina Rodrigues (1932:54) esclarece que seguramente esse assentamento quilombola constituiu-se de negros bantos. Essa afirmação se baseia no fato de que em Palmares, os negros tinham a mesma prática religiosa fundada pelos Congos, no qual se elegia rei e rainha em festejos à N.S. do Rosário, costume este que se diferenciava da prática religiosa de negros da Bahia, de origem Nagô.

De modo geral, a possiblidade de ter havido uma língua geral negra se deu em função das condições e necessidades iminentes de o negro escravizado ter de se comunicar e interagir com seus pares. Como aponta Mattoso Câmara (1975:30) “contingentes das mais variadas nações negras, quer do grupo Bântu, quer de tribos nãoBântu, [...] tinham necessariamente de criar uma língua de compromisso para intercurso". Assim, entendemos haver a língua da senzala, onde se cultivava a fala africana; e a língua de interação, no qual se tinha o português do colonizador e a língua geral indígena.

Robert Avé-Lallemant (apud Rodrigues, 1983:33), em visita à Bahia em meados do século XIX, ratifica a existência de uma língua geral nagô na Bahia ao dizer que "poucos negros falavam português fluente [...] tagarelavam no seu dialeto nagô" e que, "só precisavam dum chefe na sua língua africana nativa para desencadearem um golpe precipitado". Atento também ao predomínio da língua nagô na Bahia, Nina Rodrigues (1932) reproduz fotografia de 1895, contendo em destaque inscrição em língua africana em um açougue na Baixa dos Sapateiros. Nela se lê: Kosi obá Kan afi Olorun, ou seja, Só há um rei que é Deus. (cf. Rodrigues, 1932:200-203).

Já a existência de uma língua geral quimbundo no norte brasileiro, não conseguimos na literatura fatos que descrevessem seu uso comum. Todavia nos parece sensato ter havido uma língua geral negra de origem banto na região norte, sobretudo à época do intenso tráfico negreiro motivado pela proteção dos missionários ao indígena e 
pela criação da Companhia Geral do Grão-Pará e Maranhão, em 1775. O objetivo dessa Companhia visava a instalação de grandes empresas agrícolas, prevendo a importação de negros africanos como principal força de trabalho, à semelhança do que ocorreu na Bahia e Rio de Janeiro ( $c f$. Freire, 2003:110; Salles, 1971:28).

Na região do Pará, a presença do negro no plantio e na criação foi mais significativa do que no trabalho doméstico, comparado a outras regiões brasileiras. Isso se deu em função da abundante presença indígena neste setor. $\mathrm{O}$ naturalista francês D’Orbigny, em visita à Belém em 1832, ressalta o grande número de “índios realizando tarefas que, em outras capitais eram executadas por negros" ( $c f$. Freire, 2003:163). Apesar disso, a obra de Salles (1971) vem revelar a ampla contribuição do negro na sociedade escravocrata paraense, não isentando destacar evidências do negro na vida urbana, sua força de trabalho, serviços e especializações.

É importante destacar ter havido três línguas mais comumente utilizadas na região do Grão-Pará e Maranhão: uma língua indígena (LGA), a outra africana (quimbundo) e, evidentemente, o português europeu. A primeira era mantida como língua de comunicação interétnica. Era a língua do comércio e dos tratos entre patrão e escravizados. A segunda, uma língua particular dos negros, considerada como língua falada na senzala. Já o português era a língua da administração, falada pelos brancos ou por falantes negros e índios bilíngues em língua geral amazônica e língua portuguesa. Nesse contexto, falantes de língua geral e de língua africana tornavam-se bilíngues em português ou permaneciam monolíngues em língua geral amazônica; enquanto falantes de língua portuguesa tornavam-se bilíngues em língua geral amazônica. A consequência dessa babel linguística vai implicar, em maior ou menor grau, em alterações no plano linguístico tanto das línguas dominadas (africanas e indígenas), quanto da língua dominadora (português).

Em algumas circunstâncias, o contato linguístico pode favorecer a formação de línguas crioulas:

[...] Os crioulos são línguas naturais, de formação rápida, criadas pela necessidade de expressão e comunicação plena entre indivíduos inseridos em comunidades multilingues relativamente estáveis. Procurando superar a pouca funcionalidade das suas línguas maternas, estes recorrem ao modelo imposto (mas pouco acessível) da língua socialmente dominante e ao seu saber linguístico para constituir uma 
forma de linguagem veicular simples, de uso restrito mas eficaz, o pidgin, que posteriormente é gramaticalmente complexificada e lexicalmente expandida, em particular pelas novas gerações de crianças que a adquirem como língua materna, dando origem ao crioulo. (Pereira $\left.{ }^{8}, \mathrm{~s} / \mathrm{d}\right)$

Presumimos que a presença de negros africanos provenientes de regiões onde comprovadamente já se falava crioulo, como em Guiné (pertencente ao Grupo Crioulo da Alta-Guiné, o mais antigo grupo de língua crioula de base portuguesa) e São Tomé, notadamente facilitou as relações de contato entre colonizador e negro escravizado. Isso também pode ter servido de base para comunicação com outros grupos linguísticos de origem africana.

A primeira fase do tráfego de negros escravizados chegados à região do GrãoPará e Maranhão (1662) procedeu, principalmente, de Cachêu, Cabo Verde e Guiné. Dotadas de língua crioula de base portuguesa, esta condição nos remete a estudo de Petter (2009:159) no qual aponta "notáveis semelhanças encontradas na concordância de gênero e número do sintagma nominal entre os crioulos de Guiné-Bissau, Cabo Verde, São Tomé e Príncipe e variedades não-padrão do PB”. No mesmo sentido está a percepção de Mattoso Câmara (1975:30) ao proferir que, “[...] na qualidade de escravos ligados a todas as suas principais atividades, propiciou o desenvolvimento de um português crioulo, que uniu entre si os negros das mais diversas proveniências".

Apesar da complexidade linguística em solo amazônico colonial, algumas línguas fizeram parte do repertório comum nas relações sociais e de trabalho. Antes mesmo da interação entre as numerosas línguas indígenas e africanas com o português europeu, a região do Grão-Pará e Maranhão já havia adotado a língua tupinambá como língua de intercurso. Ao longo dos tempos o contato com as diversas línguas indígenas e com o português lusitano determina variantes na língua tupinambá de origem, bem como sua utilização em ampla área territorial amazônica contribuem para caracterizá-la como língua geral falada na Amazônia ou, língua geral amazônica (doravante LGA). Todavia, isso não exime a possibilidade de ter havido também nessa região uma língua

\footnotetext{
${ }^{8}$ Investigadora do grupo Língua e Diversidade Linguística da Universidade de Lisboa-Pt.
} 
geral negra falada nas senzalas, a considerar a etnia africana trazida à região paraense, uma provável língua negra de origem banto.

Ao longo dos dois séculos que separam a diminuição da LGA do efetivo uso da língua portuguesa em terras paraenses, é razoável haver traços morfossintáticos de substrato afro-indígena na formação do português contemporâneo dessa região. Isso nos autoriza a levantar a hipótese de que em locais mesmo pouco distantes do grande centro urbano, possam ser revelados traços desse substrato na fala do português de comunidades de histórico africano e/ou indígena. Com isso, a pesquisa teve como foco o exame de falares quilombolas, especificamente da comunidade Siricari (Marajó-PA), constituída de nítidos traços de origem étnica africana e indígena.

\subsection{Referencial teórico e metodológico}

Este trabalho propõe uma investigação interdisciplinar ao relacionar linguística a aspectos históricos e antropológicos. O enfoque maior está concentrado na observação de aspectos morfossintáticos do português falado na comunidade quilombola Siricari, com ênfase na abordagem histórica das relações de contato linguístico ocorrido no período colonial.

O estudo se beneficia de muitas contribuições teóricas no campo da etnografia, história e análise linguística. Foram adotados princípios funcionalistas amparados em Benveninste (2005), Givón (2012), Mattoso Câmara (2001, 1975, 1943), Castilho (2012), Levinson (2007), Anderson \& Keenan (1985) entre outros. No âmbito da etnografia e etnolinguística, tomamos como base estudos de Salles (1971), Oliveira \& Praça (2013), Roncarati \& Abraçado (2003), Pacheco (2010), Baxter \& Lucchesi (2009), Mattos e Silva (2004), Freire (2003, 2004), Petter (2006, 2007, 1996), Aikhenvald (2002), Heine \& Kuteva (2005) entre outros.

Os dados linguísticos utilizados neste estudo foram coletados em trabalho de campo entre os meses de março de 2014 a abril de 2015, em aproximadamente 10 horas de gravação em modo digital. Para além do tempo reservado à gravação, as visitas consistiram também em conhecer a história daquele lugar. Assim, surgiram oportunidades para conhecer quilombos vizinhos, dos quais percebemos relações interpessoais bastantes próximas; ouvimos pessoas do comércio de Salvaterra (cidade que abriga a comunidade Siricari), que nos traziam relatos interessantes sobre a vida, 
cultura e sociedade marajoara; em meio às andanças pela cidade pudemos distinguir as áreas mais comumente frequentadas por turistas, comparado aos locais de moradores nativos e entre outras experiências, também não faltou a visita à fazenda de criação de búfalos, embora localizada na cidade vizinha (Soure) de Salvaterra.

Estes momentos foram enriquecedores, uma vez que conseguimos visualizar a forte constituição africana e indígena exemplarmente tratada por Vicente Salles em sua obra $O$ negro no Pará. Um fator que vale a pena registrar é o quantitativo de empresários estrangeiros, sobretudo franceses e alemães, nos locais turísticos. Esse fato nos remeteu, a posteriori, à narrativa de um dos moradores da comunidade Siricari ter nascido e vivido, até se casar, em uma fazenda de franceses. Esse informante nos relatou que seu pai havia, igualmente, nascido e vivido toda a sua vida nessa fazenda. Apesar do interesse à parte que tivemos por esse fato, o informante não se lembrava de muita coisa para nos dizer. Somado a isso, em uma conversa informal, sem qualquer gravação, o informante nos relatou nomes de ferramentas comumente usadas em roça, contudo, com denominações totalmente distintas, a ponto de seu filho ter que as traduzir à designação que seria reconhecida por nós. A impressão que nos deu é de que se tratava de nomes franceses ou de pronúncia bastante próxima ao francês. Das palavras empregadas pelo informante, não arriscamos reproduzi-las aqui sem o devido cuidado científico da gravação.

Quanto ao corpora da pesquisa, este foi obtido a partir de gravações de conversas livres in loco em gênero narrativo e colhidas informações sobre o modo de vida, atividades habituais, tradição, mitos, saberes amazônicos, entre outras. O alvo das gravações foi obter registros de fala espontânea como amostragem linguística em narrativas que descrevessem a história da comunidade. Abaixo listamos os temas mais abordados na constituição das amostras de fala espontânea.

(i) História da comunidade: trajetórias como a cabanagem ${ }^{9}$, desafios no início da comunidade, primeiras casas, etc.

\footnotetext{
9 A revolta dos Cabanos ou Cabanagem foi um movimento popular ocorrido na Província do GrãoPará, na década de 1830, no qual camadas pobres da população conseguiram ocupar o poder de toda a província.
} 
(ii) Costumes e tradições: as festas locais, narrativas populares (lendas e mitos) o modo de vida na comunidade, o extrativismo, a caça.

(iii) Sabedoria adquirida dos antepassados: desafios das parteiras, conhecimento das ervas, as doenças e as curas, a religião, o sobrenatural.

(iv) Problemas: dificuldade de acesso à cidade, escolarização deficiente, invasões, reconhecimento da posse da terra, baixo investimento público, projeto Luz para todos e Minha casa minha vida.

Em uma breve observação, notamos que a língua portuguesa esteve mantida, principalmente pelos mais antigos, apenas por meio da oralidade, ou seja, em alguns aspectos a formalidade em que se institui a escrita poderia encobrir marcas características da fala na obtenção do corpus. Deste modo, optamos por informantes mais idosos, uma vez que teríamos o benefício também de relatos referentes à história da comunidade.

Como se pretendiam narrativas de coletadas de maneira informal, os locais em que elas se realizaram foram os mais diversos, como na cozinha, no quintal, na mesa do açaí, no caminho para o tanque escavado, na carroça de búfalo etc. Com isso, em alguns momentos, a gravação traz a participação de ruídos de crianças, chuva, animais, entre outros elementos que nos levaram a recortes ou perda de fala, tornando a gravação por vezes incompreensível.

O critério de seleção dos informantes priorizou a variante idade ou aqueles que tivessem maior tempo de permanência na comunidade. A faixa etária destes variou entre 70 a 98 anos. Posteriormente, registramos depoimentos de familiares com idade entre 40 e 60 anos, com vistas a obter dados linguísticos para um possível cotejo destes com os primeiros.

Deste modo, tivemos para a variante idade o seguinte arranjo: faixa 1: 40 a 59 anos; faixa 2: 60 a 79 anos; faixa 3: acima de 80 anos. A amostra destinada a análise compõe três células, com três informantes em cada uma, num total de 09 informantes. Apesar de estabelecer o foco para a variante demonstrada, destacamos no quadro abaixo informações adicionais que ao longo da investigação consideramos importantes para análise, tal como a variante escolaridade. 
Quadro 1- Composição do corpus do português falado na comunidade Siricari - Marajó-PA

\begin{tabular}{lllll|llllll|llllll}
\hline \multicolumn{5}{c|}{40 a 59 anos } & \multicolumn{5}{|c|}{60 a 70 anos } & \multicolumn{5}{|c}{ acima de 80 anos } \\
\hline SR-03 & F & $53 a$ & Ef & Fr & SR-07 & F & $73 a$ & Ef & N & SR-01 & F & $90 a$ & An & N \\
SR-05 & F & 47 & Ef & N & SR-10 & F & $72 a$ & Ef & N & SR-02 & M & $94 a$ & An & N \\
SR-09 & F & $56 a$ & Es & Fr & SR-04 & M & $59 a$ & Ef & N & SR-08 & F & 80a & Ef & N \\
\hline
\end{tabular}

a. Comunidade: SR, Siricari.

b. Identificação do informante na amostra original: 01, por exemplo.

c. Sexo do informante: $\mathbf{F}$, feminino; $\mathbf{M}$, masculino.

d. Idade do informante: 94a, noventa e quatro anos, por exemplo.

e. Nível de escolaridade: An analfabeto; Ef, ensino fundamental; Em, ensino médio; Es, ensino superior.

f. Tempo fora da comunidade: $\mathbf{F r}$, o informante viveu fora da comunidade pelo menos de seis meses; $\mathbf{N}$, o informante nunca viveu fora da comunidade.

Para a constituição da base de dados fizemos a transcrição das gravações orais utilizando o programa Transcriber, distribuído como software livre. Atentamos para que fossem preservadas, o quanto possível, as características da fala dos informantes principalmente no nível morfossintático. Para a reprodução escrita dos depoimentos gravados, seguimos a referência da Chave de Transcrição do Libolo, elaborado pelo Grupo de Estudos de Línguas em Contato (GELIC-USP), coordenado pela Profa. Dra. Márcia Santos Duarte de Oliveira. As transcrições do corpora receberam denominações referente à comunidade (SR), número da gravação (01), mês e ano - e.g. SRInq01_abril2014.

Quanto à organização do corpus específico levamos em conta os seguintes critérios: (i) ausência/alternância de concordância verbal em $1^{\mathrm{a}}$ e $3^{\mathrm{a}}$ pessoas do singular; (ii) ausência/omissão de aspectos gramaticais (preposição, artigo, verbo, conjunção), (iii) emprego de pronome reto ou verbo no final de sentença.

Este estudo está organizado em três capítulos seguidos das considerações finais, referências bibliográficas e anexos. No primeiro capítulo apresentamos a comunidade Siricari e alguns episódios da história africana e indígena em Marajó; no segundo capítulo, trazemos o tema contato entre línguas e os princípios que delineiam o Português Afro-Indígena; e, por fim, tratamos da descrição dos aspectos morfossintáticos elencados como variações afro-indígenas do português falado em Siricari. 


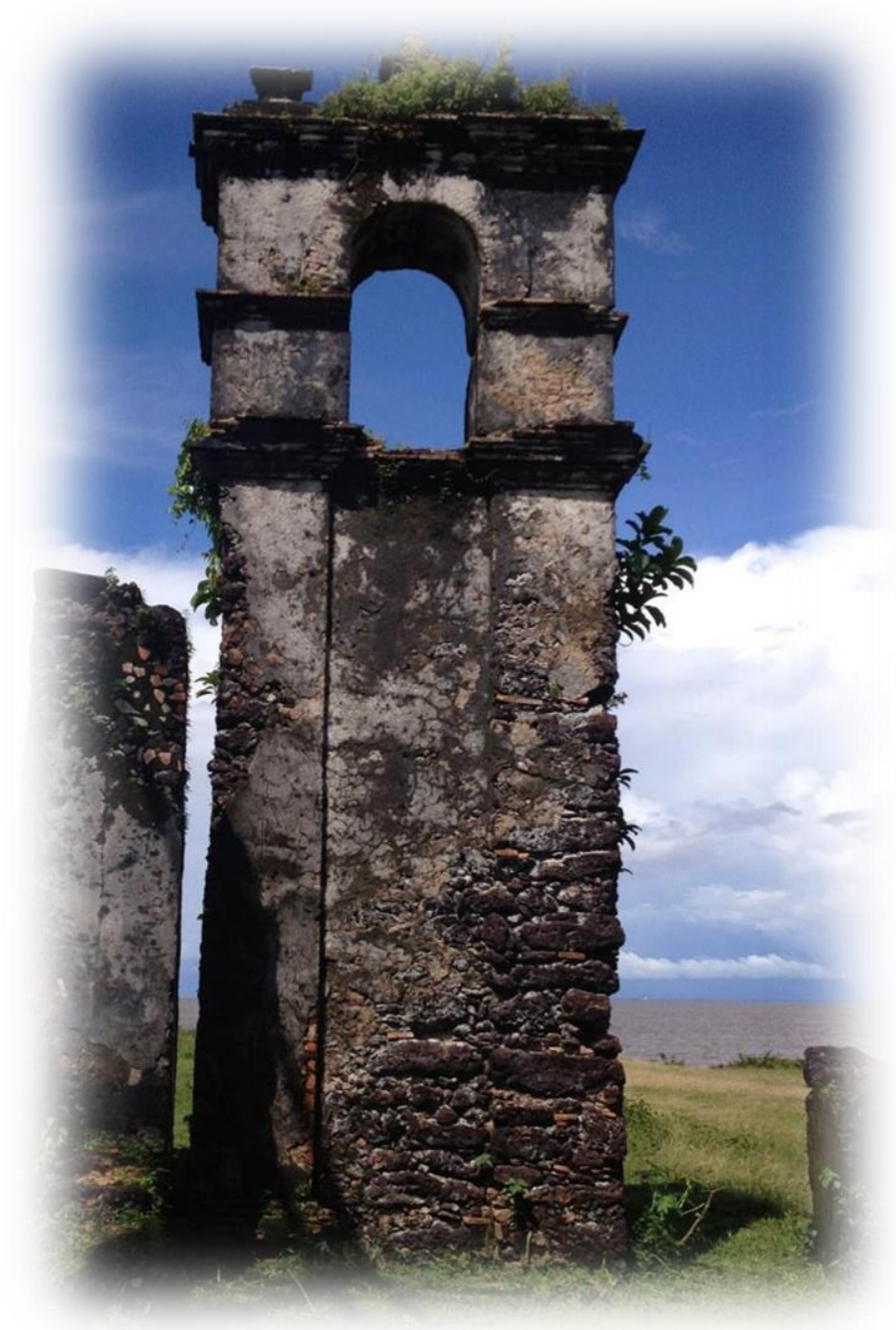

Figura 2 - Ruínas da Igreja de Nossa Senhora do Rosário em Joanes - Marajó Construída no período da missão jesuíta (1716), aparelhada com 3 altares: Nossa Senhora do Rosário, Jesus crucificado e Santo Antônio.

[...] não pode passar despercebida a informação da existência, já em 1693, da Igreja de N. S. do Rosário, devoção dos negros. Sabe-se, concretamente, que a irmandade do Rosário foi fundada em Belém a 9 de agosto de 1682 [...] demolida em 1752 e reconstruída no mesmo ano, com idênticas proporções e no mesmo lugar.

Salles, 1971:22 


\section{CAPítulo 1: A CoMunidade Siricari E UM BREVE histórico da CONSTituiçÃo ÉTNICA NA ILHA DE MARAJÓ}

Este capítulo está dividido em três seções. Incialmente apresentamos a comunidade Siricari, sua organização social, identitária e modo de vida. Na seção 1.2 mostramos um pouco da história da região de Salvaterra e a configuração das áreas de quilombos existentes no município. E, na última seção, discorremos sobre Marajó, cujas terras abrigam uma história de constituição africana e indígena imprescindíveis para se fazer compreender a cultura pelo qual a comunidade Siricari está inserida.

\subsection{A comunidade quilombola Siricari-Marajó}

Siricari é uma comunidade situada na região amazônica de Marajó, no município de Salvaterra e se autodenomina quilombola. A comunidade deteve o título ${ }^{10}$ de Remanescente Quilombola pela Fundação Palmares em 2011 e, desde então, aguarda reconhecimento de sua terra pela União, conforme consta no processo em tramitação no Grupo Regional de Patrimônio da União - GRPU. A emissão de título de propriedade coletiva tramita em fase bastante preliminar. Segundo moradores da comunidade até o momento desta pesquisa ainda não foram realizados estudos de identificação da área de delimitação da terra quilombola. Apesar disso, constam em documentos da comunidade área equivalente a 1089 hectares $(10,89 \mathrm{~km})$ procedente de herança de antepassados.

De acordo com a tradição, aqueles que têm alguma relação com o tronco familiar são chamados 'herdeiros' e, com isso, fica autenticada sua condição legítima de sucessor da terra deixada pelos antepassados. Para além do que estabelece o código civil, a relação matrimonial não vincula o direito à herança, ou seja, o(a) companheiro(a) não goza do título de herdeiro pelo casamento, mas pela longevidade na comunidade e, aos filhos, diretamente são outorgados a posse legítima da terra.

\footnotetext{
${ }^{10}$ Comunidade Siricari, localizada no município de Salvaterra/Pa, registrada no livro de cadastro geral $n^{\circ}$ 14, registro n.1.639, fl.056 -Fundação Cultural Palmares - portaria fcp no 211 de 21/12/2011.
} 
A comunidade Siricari situa-se cerca de $22 \mathrm{~km}$ da cidade $^{11}$ de Salvaterra, que toma emprestado o nome de seu município: Salvaterra (cf. Mapa 3 - Mesorregião Geográfica do Marajó). Localiza-se, também, cerca de $14 \mathrm{~km}$ do porto de Camará, único acesso ao arquipélago por via fluvial. Para se chegar à comunidade, o acesso por terra se dá parte em estrada de asfalto, parte em estrada de terra. O transporte mais comumente utilizado é moto ou carro, uma vez que o ônibus público trafega somente duas vezes por semana, chegando às comunidades pela manhã e retornando ao final da tarde.

A comunidade tem como cercanias igarapés, matas, fazendas e proximidades com outras comunidades aquilombadas. Conforme destacado no Mapa 1- Localidades quilombolas em Salvaterra - Marajó - PA), a área em verde se refere a extensão territorial onde estão localizadas terras de comunidades que se autodenominam quilombolas, bem como áreas de fazenda, todos pertencentes ao município de Salvaterra.

Mapa 1- Localidades quilombolas em Salvaterra - Marajó - PA

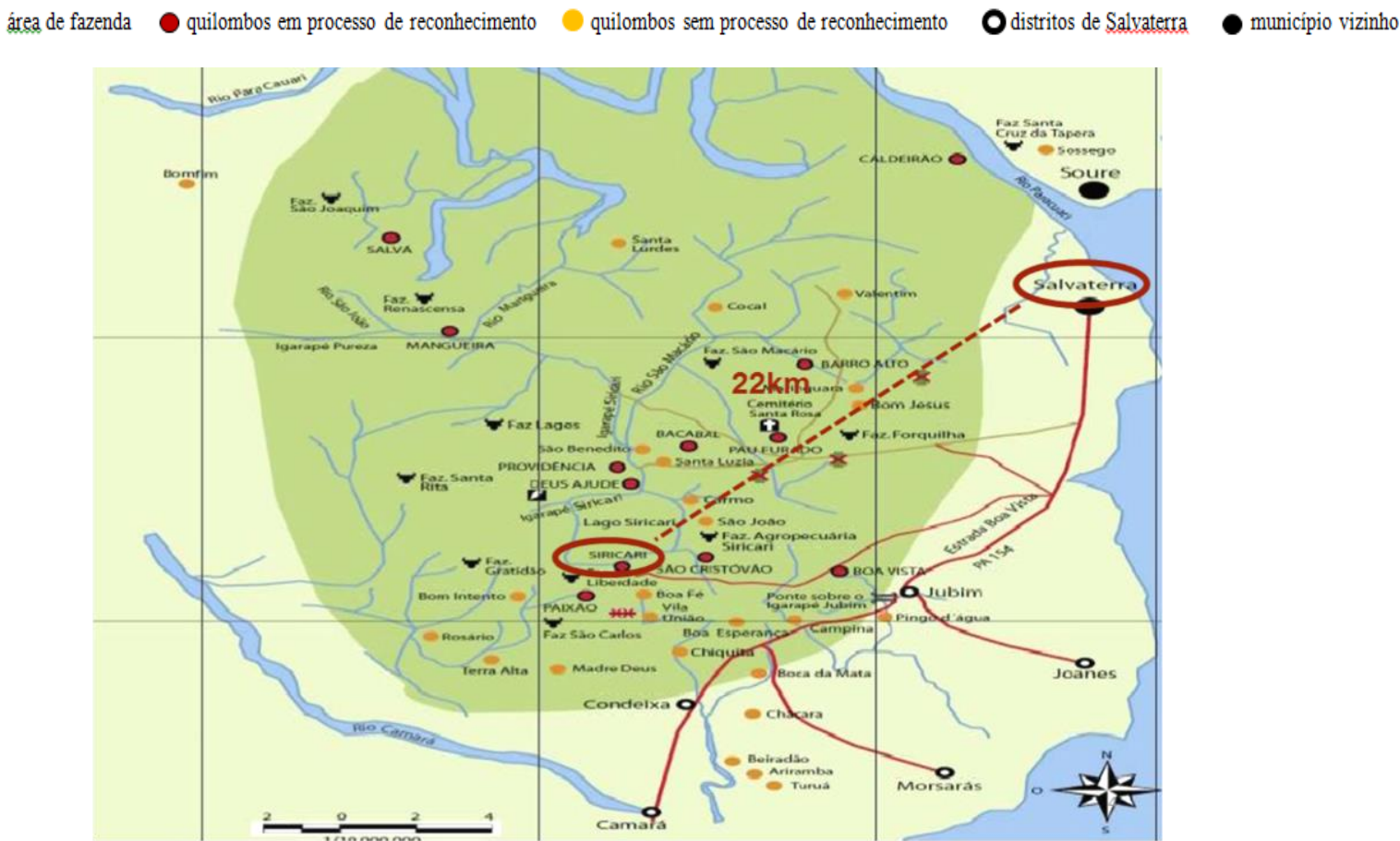

Fonte: Projeto Nova Cartografia Social da Amazônia Série: Movimentos sociais, identidade coletiva e conflitos. FASCícULO 7: Quilombolas da Ilha de Marajó. Belém: janeiro de 2006, p.7.

11 A cidade de Salvaterra pode ser caraterizada como centro rurbano, termo emprestado de Bortoni (in Chaves, A.S. Fotografias sociolinguísticas.. Campinas: Pontes, 1989). Ou seja, uma cidade composta de órgãos públicos, escolas, posto de saúde, cartório e comércio em geral, mas carente de recursos fundamentais como Hospital e planejamento urbano. 
O mapa ilustra a grande extensão de áreas quilombolas do município, restando algumas áreas (em claro) nas quais não há registro de terra quilombola. Apesar de as famílias em Siricari possuírem documentação do espaço físico distinto a cada grupo familiar, pagarem impostos anuais e aguardarem processo de demarcação de terra quilombola, depoimentos denunciam a pressão e as constantes ameaças de fazendeiros e seus familiares, que constroem suas cercas comprimindo aos poucos o espaço das terras quilombolas. Quando não, estes mesmos fazendeiros pressionam os aquilombados a negociarem suas terras a troco de acordos desonestos, valendo-se não só de sua ingenuidade, mas, também, por meio de coação aos herdeiros. Um aspecto que percebemos contribuir para a posse ilegítima da terra é a condição de campesinato pelo qual vivem as comunidades quilombolas. Caracterizada pelas práticas de uso comum do solo, inexiste demarcação do perímetro da terra e isso suscitar conflitos entre quilombolas e fazendeiros.

A exploração do solo ocorre de modo consensual entre os moradores da comunidade. Segundo Acevedo (In Godoi et alii, 2009:218) “os sistemas de uso comum representam soluções elaboradas historicamente [...] e seguem os ditames de uma cooperação ampliada e de formas de uso comum da terra, dos recursos hídricos e florestais". As famílias têm seu espaço para roça, criação de pequenos animais, pesca, bem como área para extrativismo. É comum a produção de farinha, tucupi e urucu (urucum) apenas para uso familiar, contudo o excedente torna produto de venda na própria comunidade ou é comercializado em feira na cidade de Salvaterra, auxiliando a renda familiar.

A organização não apenas do espaço comum, mas igualmente das relações sociais e econômicas compreendem também a edificação de um tanque escavado para criação de peixe, construído com apoio do Conselho de Assistência Social (CEAS) e de recurso federal. Em forma de cooperativa, a construção do tanque busca movimentar a economia dos cooperados e suster as famílias envolvidas na conservação da piscicultura. A efetivação deste projeto ocorreu em 2014, tendo sua primeira produção obtida em novembro do mesmo ano. No entanto, após essa amostragem os cooperados aguardam recursos para a compra de embriões e materiais (furtados pelos moradores não-cooperados), o que parece ser um lento e burocrático processo de repasse de verba para a comunidade. 
A prática da pesca de subsistência ainda é bastante importante para a comunidade. Em pequenos barcos, pescadores partem bem cedo e permanecem durante uma semana percorrendo alto rio. O dia de seu retorno é motivo de euforia na comunidade. São recebidos carinhosamente com alguma refeição, ao mesmo tempo em que são retirados dos isopores peixes frescos, e repartidos entre as famílias dos pescadores. O excedente é vendido a preço irrisório, comparado ao valor visto na cidade, a famílias vizinhas. O costume da pesca é constante não apenas em Siricari, mas igualmente em outras comunidades através dos rios Saco, Mangueira, Siricari e Lago Arari.

Mapa 2- Território de pesca das comunidades quilombolas

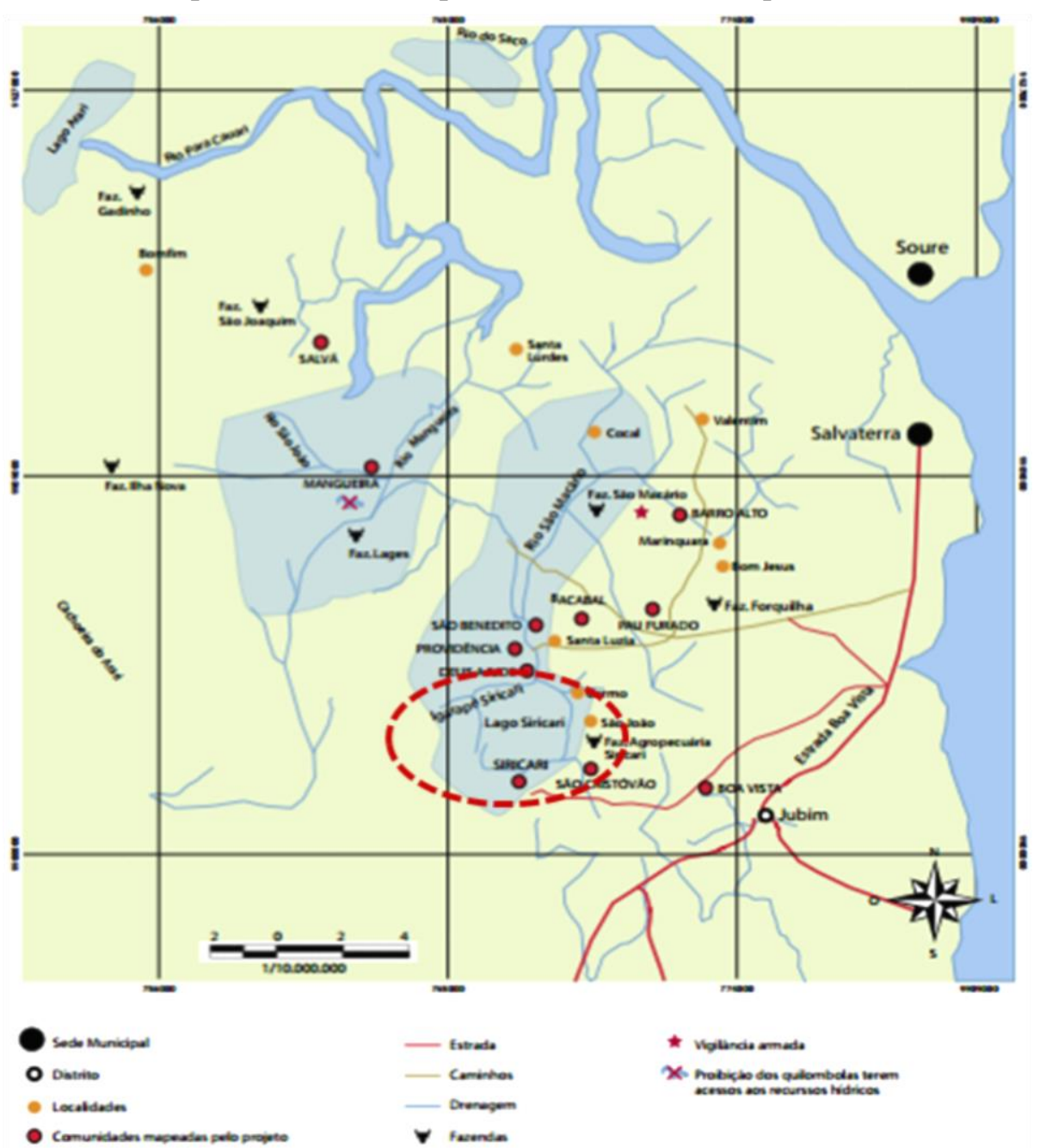

Fonte: Projeto Nova Cartografia Social da Amazônia Série: Movimentos sociais, identidade coletiva e conflitos. Fascículo 7. Quilombolas da Ilha de Marajó. Belém, janeiro de 2006. p. 10. 
Além da atividade pesqueira, constatamos a prática da caça para sustento familiar. Neste caso, os animais capturados se limitam apenas ao consumo da família, não restando para moradores próximos ou para venda.

A comunidade possui uma escola de Ensino Fundamental ${ }^{12}$, inaugurada em 1992, e funciona em regime multisseriado, abrangendo os níveis alfabetização até o $9^{\circ}$ ano. Conforme relato da professora, há materiais suficientes para o ensino, mas a qualidade da educação é reduzida em função do sistema multissérie em que é regido. Estudantes de ensino médio são conduzidos para escolas na cidade de Salvaterra em transporte da prefeitura, eles dizem enfrentar sérios problemas no transcurso no período de chuvas, por vezes impedindo de chegar até a cidade.

Diante disso, moradores da comunidade disseram que os mais novos têm abandonado os estudos para se instalar em casas da cidade de Salvaterra em busca de trabalho. Isso os leva a se distanciar não apenas do local de origem, mas de suas crenças, histórias, costumes. Nesse caso, o que verificamos é a permanência fixa apenas da população mais idosa na comunidade. Apesar da aparente evasão escolar e local, percebemos que a presença da Universidade Federal do Pará (UFPA - campus Soure) e a Universidade Estadual do Pará (UEPA - campus Salvaterra) incentiva a reflexão sobre os valores locais e isso vem inibir a saída de jovens em busca de trabalho na cidade de Belém, o que era habitual.

Grande parte das $\operatorname{casas}^{13}$ na comunidade são erguidas de madeira e em condições precárias. O abastecimento de água provém de poço e há energia elétrica para as moradias, exceto para uma família que vive em área um pouco mais distante das demais, não havendo energia elétrica permanente, apenas gerador.

Quanto ao aspecto religioso há na comunidade uma capela católica e outra evangélica. Moradores contam que tem havido constante adoção dos preceitos evangélicos na comunidade, reduzindo a manifestação aos princípios católicos ou inibindo sua continuação e/ou adoção à crença católica. Este comportamento tem se

\footnotetext{
12 A construção em alvenaria (foto anexa) foi inaugurada em 1992. Inicialmente a sala de aula ocupava um espaço da casa cedido pela família Figueiredo, pois não havia um local específico para isso. A professora era mantida pelo município, apesar da grande rotatividade e, por vezes, inconstância da atividade.

${ }^{13}$ Imagens em anexo
} 
mostrado contrário às culturas amazônicas, conforme estudos de Maués (2005; 2012; 2007) nos quais indica um universo religioso na Amazônia submerso nas religiões africana, indígena e europeia no qual tomam como base o catolicismo, distinguindo os povos amazônicos em seus costumes e tradições.

A distinção de valores religiosos em Siricari tem provocado o desaparecimento de eventos ligados ao sincretismo cristão (ou práticas religiosas populares) carregados de forte representação cultural, típicos de comunidades ribeirinhas. $\mathrm{O}$ ato de pagar promessas, a simbologia das romarias, das procissões, a prática da benzedeira, a reza em latim - praticada na comunidade até pouco tempo, conforme relatos,- entre tantos outros eventos de sincretismo religioso típico na região amazônica tem sido fracamente celebrado nesta comunidade. Esse é um indicativo da perda dos costumes tradicionais impregnados de saberes imateriais e configura, igualmente, prejuízo ao patrimônio cultural que distingue comunidades quilombolas amazônicas em sua inter-relação com os saberes e sincretismos afro-indígenas amazônicos.

Apesar disso, comunidade Siricari juntamente com as demais comunidades quilombolas pertencentes ao município de Salvaterra, realiza todos os anos a Festa da Tradição, no mês de julho, e a Festa dos Quilombolas, no mês de novembro. Cada ano uma comunidade se responsabiliza pela organização. São três a quatro dias de comemoração na Festa dos Quilombolas, que se estendem ao Dia da Consciência Negra. Algumas das atividades representam um resgate à tradição e à preservação da cultura e historicidade quilombola. Em forma de torneios ou como chamado pela comunidade também como jogos quilombolas há atividades que envolvem habilidades como canoagem, mergulho, corrida rústica, luta marajoara, corrida de búfalo que, além de marcarem o costume de seu povo constituem vestígios de uma cultura muitas vezes resultante do contato africano e indígena.

Sob influência da tradição religiosa da região norte brasileira, as festas de origem católica como o Círio - de grande repercussão em Belém - e a Festa do Mastro se mantêm na comunidade e são acolhidas por todos. Nessas festas, independe da crença adotada, tanto católicos quanto evangélicos participam dos festejos. Nas festas de tradição é comum servir a (i) Tiborna, bebida de procedência indígena; e em algumas comemorações tradicionais as danças típicas da região como o (ii) carimbó e o (iii) Siriá fazem parte das celebrações. 
Tanto a Tiborna como o carimbó evocados nas comemorações quilombolas sinalizam a forte confluência entre as culturas africana e indígena. A (i) tiborna ${ }^{14}$, bebida feita à base de mandioca ralada e fermentada, dizem ser uma especiaria da culinária indígena, apesar de estar presente nos festejos quilombolas. $\mathrm{O}$ mesmo modo de preparo é conhecido em algumas aldeias indígenas como caxiri ou cauim, catimpuera.

A dança (ii) Carimbo $^{15}$ representa seguramente um misto cultural: dizem ter sido criada pelos índios Tupinambá e aperfeiçoada pelos negros africanos, que fizeram seu ritmo com mais vibração, como uma espécie de variante do batuque africano. Inclusive, no Glossário de Vicente Chermont de Miranda (apud Salles, 1971:103) consta o termo carimbó como legitimamente africano incorporado à linguagem regional. A composição cultural do Carimbó possui, também, traços de expressão corporal de danças lusitanas como dedos 'castanholando' na marcação do ritmo.

E (iii) o Siriá, outra dança folclórica do Norte constitui, do ponto de vista musical, uma variante do batuque africano. A dança surgiu como um tipo de comemoração pela fartura de alimento conseguido pelos escravos no final do dia pela captura de siris na praia. O nome vem de siri (crustáceo) e a tonicidade decorre da analogia a cafezá para o local da plantação de café, arrozá para o local de plantação do arroz, canaviá para o local de plantação da cana e, assim, passaram a chamar de siriá, para o local onde todas as tardes encontravam os siris com que preparavam seu alimento diário (cf. portal da Amazônia.com.br).

Nas Festas de Tradição há, também, a presença da célebre figura do Búfalobumbá, representado pela alegoria de Mestre Damasceno ${ }^{16}$. A analogia ao boi-bumbá remete à história trazida por Frias ${ }^{17}$ em 1883 (apud Salles, 1971: 194) ao “bomba” (sic), no qual assinala que "celebrado pela gente de côr, em plena cidade do Pará, parece-me

${ }^{14}$ De acordo com moradores daquela comunidade a tiborna é feita da seguinte forma: cozinha-se a mandioca por 12 horas, depois de fria côa-se, adoça e deixa apurar pelo menos por 2 dias. As pessoas tomam essa bebida até chegar a um determinado local onde está a bandeira.

${ }^{15}$ Para saber mais ver: http://www.portalamazonia.com.br

${ }^{16}$ Mestre Damasceno Gregório dos Santos, descendente direto de escravos e índios, se identifica como afroindígena, morador da Comunidade de Mangueiras e criador da comédia lírica e folclórica do búfalobumbá, tradição em Marajó. Possui mais de 400 composições próprias, todas gravadas em sua memória e muitas entoadas pelas crianças e moradores de sua terra. É reconhecido nacionalmente pela dedicação em preservar as impressões culturais de seu povo. (cf. http://www.diariodopara.com.br)

17 Sanches de Frias escreveu a obra Uma viagem ao Amazonas, datado de 1883. Nessa obra contém o desenho do Boi-Bumbá dançado nas proximidades de Santarém, cidade a oeste do Pará, foz do Rio Tapajós, no Amazonas. (cf. cap. 13: O Bombá, p. 137-46, apud Salles, 1971) 
representar uma cerimônia gentílica, importada pelos prêtos africanos”. Nesta passagem chamamos a atenção para a simbologia representada pelo boi-bumbá, conforme descrito por Ramos (apud Machado Filho, 1985:61-64) demonstrando que "o totemismo do boi é largamente disseminado entre vários povos bantos, onde em algumas tribos toma um aspecto francamente religioso". A festa do Divino é um claro exemplo da presença cultural africana no país. Na comunidade Siricari, os moradores mais antigos contam que no passado criadores ofereciam bois que seriam mortos e a carne distribuída entre todos da redondeza. Este comportamento se conserva semelhante ao rito Boi do Divino, observado por Ramos (apud Machado Filho, 1985) em localidades africanas.

A celebração do boi-bumbá e as crendices ligadas ao boi, como práticas supersticiosas em que chifres de bois são enfiados nas cercas de roças contra mauolhado e coisa-feita, são igualmente análogas ao que Ramos nos conta quanto às manifestações ocorridas em solo africano. Isso nos mostra que as tradições trazidas pelos negros africanos se mantêm, até os dias atuais, imune às influências ameríndias, apesar da forte disseminação dessa simbologia em localidades de intenso contato como na Amazônia.

A representação do boi-bumbá nas comunidades quilombolas próximas à Siricari ganha característica particular ao adotar a representação do búfalo, reportando à tradicional criação deste animal na região de Marajó. Mestre Damasceno, grande incentivador da manutenção das culturas marajoaras e das africanidades e indigenísmos, tornou-se uma pessoa emblemática ao reinventar a tradição do boi na figura do búfalobumbá.

Integrante da comunidade quilombola de Mangueiras e crescido na comunidade de Salvá, fundada por seu pai Francisco, Mestre Damasceno tornou-se representante da cultura dos remanescentes quilombolas em Salvaterra. Ele descreve em suas narrativas orais a história também de tanta gente dali, traduzida em seus repentes, expõe a cultura material e imaterial tão importante para a identidade daquele povo.

A biografia de Damasceno revela um passado ainda presente naquela região aquilombada de Salvaterra, provocando proximidade latente no outro nas narrativas de tempos amargos da escravidão:

Meu nome é Damasceno Gregório dos Santos, nascido na vila de Mangueiras no ano de 54. O meu avô foi vendido aqui pro Marajó 
com a idade de 7 anos, ele era maranhense, ele foi vendido no ver-opêso, a troco de uma garrafa de cachaça e um cacho de banana. Eu sou neto de escravo misturado com índio, minha avó fugiu de uma aldeia de Cametá, contavam que ela veio de lá menina e veio acompanhada da mãe e do pai. (Nunes, 2013:104)

No entendimento de Pacheco (2012:12) "as continuidades históricas permitem recriações, revisões, invenções, pois contextualiza sujeitos, motivações e perspectivas de mundo". É neste sentido que as narrativas da inter-relação entre negros e índios na região de Salvaterra, nas comunidades quilombolas e mesmo na comunidade Siricari remetem à trajetória dessas famílias. Não são apenas histórias, mas biografias que mantêm viva a memória coletiva da comunidade. Nos quilombos visitados em Marajó parece haver uma identificação dos moradores com a constituição afro-indígena. Essa é uma característica contrária do que se tem observado em comunidades indígenas como nos povos Tremembé (CE) e Tapeba (CE), dos quais se imprime o caráter indígena sem a participação sucessora de etnias de descendentes africanos. Contrariamente do que vemos nas comunidades marajoaras eles se autodenominam quilombolas, mas não há qualquer negação de sua descendência indígena. Esse aspecto é uma interseção entre o comportamento social afro-indígena adotado intimamente pela comunidade Siricari (entre outras comunidades marajoaras) e as características etnolinguísticas defendidas neste estudo a partir da perspectiva do Português Afro-indígena.

Exemplo dessa inter-relação étnica em Siricari está no depoimento de uma das informantes, em cuja narrativa mostra a origem paterna natural de quilombo marajoara, e a origem materna indígena.

A minha mãe era índia, era filha de índio branco. Minha mãe, o pai dela era. O pai dela era índio mesmo, né. Aí eles conseguiro pegá essa família amansá e foi aí ele já saiu já índio branco porque ele já nasceu domesticado. E o meu pai... o meu avô era filho daí de Boa Esperança. (SR-05)

Breves registros descrevem a trama étnica, social e cultural presente em grande parte das comunidades quilombolas do município de Salvaterra, compreendendo ainda a comunidade Siricari. Fatores como estes importam ao considerarmos que cada povo traz, intrinsecamente, percepções de vida que podem particularizar a maneira de pensar, 
de entender o mundo e, consequentemente, de se expressar. Nesse sentido, o capítulo seguinte irá mostrar um pouco mais das características sociais e culturais especificamente da comunidade Siricari, de modo a incluir propriedades ao estudo etnolinguístico a ser descrito no capítulo (3) deste estudo.

\subsubsection{Breve histórico da comunidade Siricari}

Nesta seção tratamos de alguns pontos relacionados à territorialização e reconhecimento da comunidade Siricari como remanescente quilombola. Depois assinalamos alguns costumes, histórias, marcas de uma fronteira cultural africana e indígena. Por fim, uma pseudo-etmologia sobre o sentido da palavra Siricari, uma vez que, embora moradores dessa comunidade tenham buscado vestígios sobre a origem deste nome nada há de concreto para formalização de seu significado.

Siricari é uma comunidade que nasceu em terras de fazenda no período colonial, ainda no rastro do regime de sesmarias, ${ }^{18}$ que era um sistema de incentivo à ocupação e exploração do solo brasileiro proposto pela coroa portuguesa. Então, a posse da terra e a formação de povoados ocorriam a partir de fatores como a seção de terras a donatários da coroa, e havia também lugares chamados 'sobras de terras' de fazendas e sítios que eram ocupados por quilombolas, indígenas e mestiços decorrente de crise na pecuária ou das lutas da Independência e da Cabanagem que provocavam evasão de terras.

Sobre os meios de ocupação da terra Acevedo (in Godoi et alii, 2009) nos conta que:

[...] os povoados negros revelam origens diferenciadas, assim como uma diversidade de formas de acesso a terra, o que compreendem ocupações, doações, posses registradas, compras e heranças. (p.215)

Conforme consta em arquivo da Fundação Palmares (2011), o processo de territorialização e organização social de Siricari data dos anos 1850 em diante.

18 Sesmaria: refere-se ao lote de terras ou terrenos que eram cedidos pela coroa portuguesa a novos povoadores fidalgos e homens de distinção. Estes recebiam tratos enormes de terras equivalentes a 3.000 braças ou 6.600 metros para cada medida de sesmaria. A Resolução de 17 de julho de 1822 terminou com o regime de sesmarias no Brasil (cf. Rocha \& Celestino, 2010). 
Entretanto, segundo antigos nativos, antes mesmo do período em que antecede o movimento cabano (1835-1840) a região de Siricari era habitada por seus antepassados. Há relatos de que estes teriam vivido situações de fuga da 'guerra', termo usado em referência à cabanagem, nos quais negros aquilombados e índios enterravam seus pertences e se escondiam na mata até a certeza de estarem a salvos para retornarem ao seu agrupamento.

Olha, só a minha mãe diz qui qui inda tinha, né, que a bisavó dela diz que era... inda, índia, né, ela é... que quando começô aqui a guerra da cabanage, né, foi que eles interraro as coisa e correro, se escondero. Ainda a vó, non, era a mãe do finado Lili, diz que se meteu num baú grande, que antigamente usava aqueles bauzon, né, agora cobria de ropa, diz que assim que ela fez. Aí quando foro embora com o negócio da guerra, foro varando aí pelo Rosário, foro terminá lá pra Joanes, foi ali em Monsará, tudo pór lá eles foro passando. (SR-08)

O depoimento acima ratifica situações vividas por ascendentes de familiares de Siricari no movimento cabano, importante marco para que consideremos a ocupação daquelas terras por no mínimo 181 anos. Apesar do legítimo pertencimento territorial, a comunidade Siricari sempre esteve diante de situações de tensão política com fazendas vizinhas. Há casos em que o fazendeiro impede a circulação de quilombolas assentando cercas de acesso a rio ou em área de extração; apropria-se indevidamente de parte da terra quilombola ou força acordos ilícitos para colocar a cerca deles adentro a troco de algum favor devido anteriormente. As fazendas mais próximas de Siricari são Fazenda Liberdade, Fazenda Agropecuária Siricari e mais à frente, Fazenda Gratidão. Embora não se possa dizer que haja uma relação amigável entre a comunidade e as fazendas vizinhas, também não se pode afirmar, até o que sabemos, de ter havido situações extremas entre estes.

No modo de entender da comunidade, a vida campesina imprime costumes antigos de uso comum da terra e rios como a prática do extrativismo, a pesca e a caça. $\mathrm{O}$ impedimento causado por vezes pelas fazendas a essas práticas contribui para a diminuição ou mesmo extinção de hábitos singulares destes povos. Nas palavras de Acevedo (2009:216), "garantir esses domínios é a luta principal desses grupos” e, nesse caso, a busca de conhecimento que auxilie nesses domínios tem levado jovens a campos 
universitários da região e a adoção de comportamentos de preservação material e imaterial do patrimônio histórico da comunidade.

Nesse sentido, percebemos que as narrativas orais sobre a investida da cabanagem, contadas pela população mais antiga da comunidade e cultivadas pelos mais jovens, têm se tornado tradição naquele local. Esse comportamento não só mantém preservadas as situações vividas por seus antepassados, mas igualmente assinala evidentes marcas sobre o período de ocupação daquele lugar. As narrativas orais muitas das vezes tomam características fantásticas, como $O$ galo de ouro, As visagens de Uiara, O Poço seco, anexas no final deste estudo, entre outras que dão um formato simbólico a esses eventos históricos. Apesar da existência de uma postura moderna enriquecida pela educação e tecnologia, como acesso à escola e universidade, televisão e internet, a manutenção de histórias orais ainda está muito presente no interior das casas, traduzindo seus valores, princípios morais e impressões da vida mantidas pelas reminiscências do passado.

Fator importante que marca o processo de territorialização de um local é a toponímia recebida pelos primeiros ocupantes. A formação do nome do lugar acompanha não só a história daqueles que inicialmente se estabeleceram ali, como pode fornecer pistas da cultura da local e de seus habitantes. Segundo intepretação de Chaves $(2015: 5)$

O batismo dos lugares não [é] apenas um ato de descrição da nova porção de terra encontrada, mas sim [...] poderoso elemento simbólico demarcador do domínio territorial, pois o ato simbólico da atribuição de um nome baseado na própria cultura é mais relevante do que simplesmente um nome em sua língua.

Em Siricari, por vezes temos informações contraditórias sobre o significado do topônimo Siricari. Alguns dizem se tratar de homenagem a uma índia de nome Síria que viveu ali no passado. Contudo, não se sabe muito além disso, mesmo após alguns moradores pesquisarem e buscarem junto aos mais antigos qualquer pista ou fato que viesse explicar a sua significação. Com o propósito de investigar o conceito etimológico do termo Siricari, amparamos em Stradelli (Domenico, 2008) no qual aponta o sufixo cari como um termo que representa: 
"cari" = mandar; mandado. Aquele que manda, o branco, o dono, o senhor, podendo se referir também ao preto ou ao mulato se estiverem em posição de mandar. (p.227)

Em Tibiriçá (Domenico, 2008:235) cari origina-se:

[...] 1. Do aruaque "cãri", homem, varão; de onde "cari-aíba", que alterou-se para "caraíba", estrangeiro. 2. Homem branco, raça branca.

E ainda sobre o mesmo termo, porém com grafia distinta kari, Domenico (2008:562) traz o seguinte conceito:

"kari". Corresponde no neotupi ao verbo "ucara" = mandar (tupi antigo)

Ainda que em momento algum tenhamos tido a pretensão de afirmar alguma relação entre a definição trazida pela etimologia e o nome Siricari, os significados acima chamam atenção ao sugerir ser o sufixo -cari um termo designativo de senhor rico e branco. Esse fato coincide com relatos sobre a figura de Paulino Alves de Figueiredo, titular das primeiras escrituras daquelas terras, conforme contado pela comunidade.

O pai dele, aliás, que o pai dele mermo que era Paulino Alves de Figueredo, esse era um sinhô rico, branco, veio corrido daí, num sei daonde, com medo de guerra. Aí foi que diz que se abolotô aqui, né aí fez nesse tempo, fazia o... tirava a quantia que queria pra podê ir fazê as iscritura, né e fui que lhe aconteceu isso. (SR-08)

Apesar da alusão a antigos registros de posse daquelas terras, é necessário dizer que muita documentação cartorial se perdeu em decorrência de conflitos diversos, interesse particular pela posse de terras, além da mudança para o status de municipalidade de Salvaterra, antes distrito de Soure. Deste modo, a constituição histórica de grande parte das comunidades quilombolas se perdeu ao longo dos tempos em detrimento de avarias, desinteresse e/ou descuido cartorial.

Em se tratando do prefixo Siri, em cujos relatos apontam ser proveniente do nome Síria, dado a uma índia, encontramos a definição em Domenico (2008) que nos remete à dança de Marajó nos seguintes termos: 
Sîrîá. 1. Canto (A.Fernandes). 2. Nome de uma dança em Marajó. (p.902)

Vale lembrar, também, a informação sobre a origem do termo siriá que faz alusão ao crustáceo siri. Deste termo imprimiu-se a tonicidade no elemento morfológico - á em referência ao local onde escravos encontravam alimento. (cf. pág.15)

Apesar das informações tratadas pela etimologia em Stradelli, Tibiriçá e Domenico, elas não garantem a legitimidade para o significado do topônimo Siricari. A falta de registros e a insuficiência de fatos trazidos nos relatos orais impedem, portanto, descrever as reais circunstâncias de sua origem.

\subsection{Salvaterra marajoara: território afro-indígena}

Salvaterra abriga a comunidade Siricari e é o menor município pertencente à mesorregião ${ }^{19}$ do arquipélago de Marajó-PA (Mapa 3 - Mesorregião Geográfica do Marajó). O município ocupa uma área de $1.039 \mathrm{~km}^{2}$, segundo dados do IBGE. Situa-se à margem da Baia do Marajó com rio Paracauarí e é considerada a porta de entrada para a ilha através do porto de Camará.

Salvaterra, antes considerado distrito de Soure $^{20}$, elevou-se a categoria de município em 1961. Este desmembramento fez com que documentos cartoriais e estatísticas históricas condizentes ao atual município de Salvaterra permanecessem registrados como parte de Soure, hoje município vizinho. Portanto, informações e dados históricos relativos a Salvaterra podem não ser fidedignos ao seu atual perímetro geográfico.

${ }^{19} \mathrm{O}$ arquipélago de Marajó possui uma área de 104.140 km² e compõe as regiões de Chaves, Santa Cruz do Arari, Soure, Salvaterra, Cachoeira do Arari, Pontas de Pedras, Muaná, São Sebastião da Boa Vista, Curralinho, Breves, Anajás e Afuá, Gurupá, Portel, Barão de Melgaço e Bagre.

${ }^{20}$ No município de Soure habitava a antiga aldeia dos Maranauazes - grupo indígena de referência na história de ocupação da região - Tal denominação aparece em alguns arquivos/livros históricos como região dos Maranauazes sem referência ao atual nome Soure. (Ver: Ensaio Corográfico sobre a Província do Pará, p. 280) 


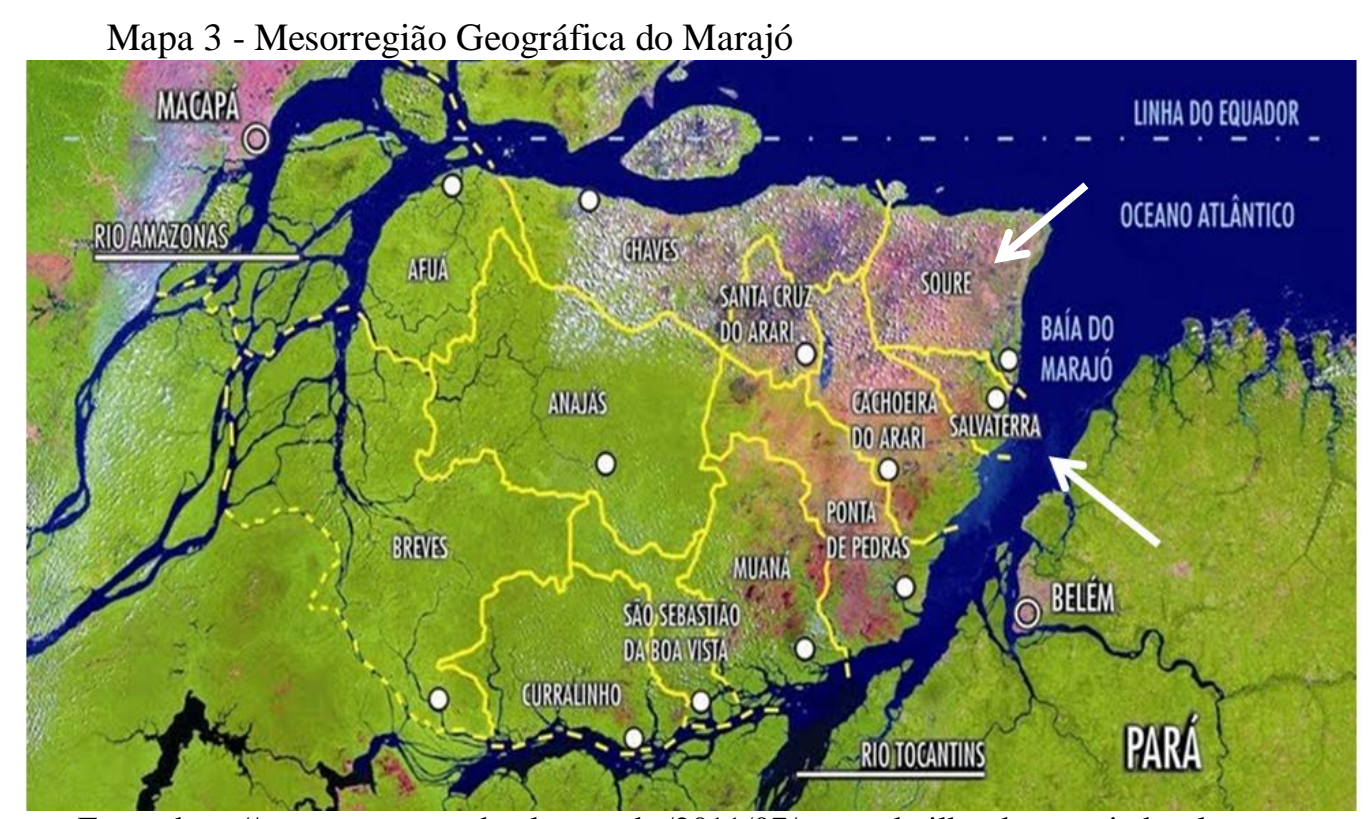

Fonte: http://www.encantocaboclo.com.br/2011/07/mapa-da-ilha-do-marajo.html

Antes da chegada dos missionários e colonizadores em Marajó a ilha era habitada por diversos povos indígenas. Segundo consta no Ensaio Corográfico da Província do Pará (2004:280) a região de Salvaterra era aldeia dos Sacácas, povos indígenas aldeados pertencentes às missões dos capuchos; na atual região de Soure (antes compreendendo município de Salvaterra), habitava a antiga aldeia dos Maranauazes e; no atual município de Chaves (antiga Ilha grande de Joanes) habitavam os Aruãs e também aldeia de povos Pyié. Apesar da fronteira sugerida nos dados do Ensaio Corográfico havia intenso movimento migratório e interação entre as diversas nações indígenas existentes na ilha.

A descrição de fragmentos encontrados por Schaan \& Marques (2012:112) em sítios arqueológicos no distrito de Joanes demonstram contornos da relação entre os indígenas e o colonizador. Oficialmente subordinado ao município de Salvaterra desde a metade do século XX, os sítios do distrito de Joanes indicam sua importância histórica em vista dos materiais de cerâmica indígena, faiança ${ }^{21}$ portuguesa do século XVII, porcelana chinesa, moedas portuguesas cunhadas em 1753, entre outros.

\footnotetext{
${ }^{21}$ Faiança - s.f. Louça de barro, argila ou pó de pedra, envernizada ou esmaltada, impermeável a líquidos e, em geral, ricamente decorada. (in Dicio - dicionário oline)
} 
Colonizada pelos jesuítas por volta do século XVIII, o município de Salvaterra traz na vila de Joanes ruínas da igreja de Nossa Senhora do Rosário ${ }^{22}$ (1716), que teria pertencido às missões dos padres capuchos de Santo Antônio. Ali habitavam os povos da tribo Sacáca, descendentes dos Aruans ${ }^{23}$ ou Arawák (Steward, 1948; Baena, 2004), pertencentes ao grupo linguístico indígena do tronco Macro-jê. São eles os responsáveis pela herança em cerâmica e sua iconografia mantidas como tradição ao longo dos tempos em toda a ilha de Marajó.

A presença interétnica nesse município, bem como em outros da ilha está representada nos diversos 'sítios de $\operatorname{contato}^{24}$, remanescentes que, conforme demonstrado no Plano de Desenvolvimento Territorial Sustentável do Arquipélago do Marajó (2007:17)

[...] testemunham um longo processo histórico ocorrido na ilha, e podem oferecer subsídios à compreensão de aspectos de sua dinâmica cultural eg., as formas de contatos interétnicos havidos entre os povos nativos, europeus e africanos.

Documentado por Baena (2004:422) a área hoje pertencente ao município de Salvaterra era a antiga vila de Monsarás (1833), que incluía as vilas de Monforte $\left(J_{o a n e}{ }^{25}\right)$, Monsarás e a cidade Salvaterra. Hoje, o município comporta 5 distritos: Salvaterra, Monsarás, Joanes, Jubim e Condeixa, abrangendo uma estimativa populacional de 21.987 em 2014, segundo censo do IBGE.

Ao tratar do parâmetro de contato interétnico entre nativos, europeus e africanos, Salles (1971) em seu capítulo sobre a composição étnica do Pará valida esse hibridismo

\footnotetext{
${ }^{22}$ Figura 2, pág. 8 deste estudo. Conta Nina Rodrigues (1932:51) que o culto a Nossa Senhora do Rosário tem sido sempre, desde tempos coloniais, confiado no Brasil aos Negros escravos, ou mais tarde livres, e em particular aos Negros Bantus.

${ }^{23}$ Meggers e Evans descrevem sítios Aruã como locais proto-históricos habitados na ilha por volta do século XIV. In: Plano de Desenvolvimento Territorial Sustentável do Arquipélago do Marajó. Um exemplar bastante interessante dessa relação cultural em Marajó é reproduzido em textos da arqueóloga Denise Schaan sobre a obra "Motivos ornamentais da cerâmica marajoara", autoria de Giovani Gallo, que comprova a autenticidade da iconografia marajoara reproduzida na obra.

${ }^{24}$ Sítios coloniais ou de contato são sítios da época do contato com os europeus como vilas, igrejas, engenhos, fazendas, chalés, com estruturas arquitetônicas e outras evidências materiais datadas do período colonial. In: Plano de Desenvolvimento Territorial Sustentável do Arquipélago do Marajó.

${ }^{25}$ Em 1754 a vila de Joannes passou dos missionários para a coroa portuguesa, vindo em 1757 a se chamar vila de Monforte. (Schaan \& Marques, 2012 p.121; Baena, 2004, p.277)
} 
étnico, mas ressalta a presença marcante do negro mesmo diante das deficientes estatísticas coloniais de recenseamento populacional na época, destacando que:

É difícil fazer o levantamento estatístico do tráfico de peças da África para a Amazônia [...] da mesma forma é difícil avaliar a imigração europeia e o extermínio dos grupos tribais indígenas. O certo é que no cômputo geral não há mais equilíbrio de estoques raciais. Há extrema heterogeneidade. Os contatos interétnicos se processaram intensamente, isentos do mais rudimentar preconceito racial, fundindo num todo os três estoques fundamentais: o branco, o índio e o negro. A presença de grupos indígenas isolados e de numeroso grupo mais ou menos marginalizado vivendo na periferia das comunidades amazônicas não invalida a tese: o negro é uma presença marcante. (p.69 - grifo nosso)

Conforme demonstrado é evidente o argumento de que a heterogeneidade étnica se compôs da mistura entre o branco, o índio e o negro em terras amazônicas e isso se estende a Marajó e seus municípios. Especialmente na zona de criação da ilha Salles (1971:135) assinala que "o produto da miscigenação se processou isento do mais elementar preconceito racial", o que resulta hoje o "tipo étnico amazônico, em cujas veias corre o sangue de brancos, negros e índios".

No entanto, a composição de um mesmo status quo, ainda que aparentemente isento de preconceito mediante a evidente heterogeneidade étnica, suscitou o viço do preconceito social em Marajó ainda nos tempos coloniais. Esse divisor de águas operou como uma bússola para a formatação das comunidades rurais de matrizes africana e indígena.

A miscigenação entre os povos indígenas e africanos vai muito além dos fatores étnicos. Ela se deveu à cumplicidade entre eles dado o regime social pelo qual foram obrigados. Desde a privação da liberdade, do servilismo forçado, a violência do degredo humano nas transações comerciais, o negro e o índio estiveram marcados socialmente. Não menos que isso, declarada a alforria do indígena em 1751 Salles (1971:25:134) conta que como forma de burlar o ato régio de liberdade do gentil, não raras vezes índias aldeadas eram forçadas ao matrimônio com negros escravizados para obtenção de descendentes cafuzos, ainda submetidos ao trabalho forçado. Como consta documentado no Annaes. v. 1, p. 147, Doc. 105 e v. 1, p. 163, Doc. 118 (ipsis litteris), 
Doc. 105

Que cessem os abusos cometidos pelos Capitães-Mores de se servirem do Indios fôrros e cazal-os com as suas escravas. Ao Capitão-mór do Pará se extranhe haver metido na fortaleza [...] tão só porque intentara reclamar contra a inobservância das Leis sobre a liberdade dos Indios.

Doc. 118

Que o capítulo do Regimento do Estado, referente ao matrimonio dos Indios, seja cumprido á risca, e não como fazem os moradores, que cazam os Indios aldeados com seus escravos e escravas, para tel-os a seu serviço, em detrimento da liberdade, que as Leis da Corôa lhes garantem.

Esse entre outros tantos males fomentaram povos de origem africana e indígena estabelecessem 'pactos de sobrevivência e luta'26 mesmo após a abolição dos negros em 1888. Conforme demonstra Salles (1971:153),

[...] negros que haviam adquirido alforrria [...] formaram com os índios uma parcela considerável da população. Marginalizada socialmente, viviam em condições muito precárias e tão lastimáveis que se podia dizer - 'mais vale ser escravo do que viver como vivem muitos homens livres'. (grifo nosso)

O aparecimento de mocambos e quilombos compartilhados pelas matrizes africana e indígena ocorreu em todos os espaços da ilha de Marajó. Antes mesmo do decreto de abolição da escravidão indígena (1755), encorajados pelo comportamento dos negros e pela oportunidade de fuga, mocambos de índios surgiram ao lado de mocambos de índios e negros em uma clara demonstração de reorganização étnicosocial. ( $c f$. Gomes, 1997:76-78).

Vale a pena comentar sobre o uso das terminologias mocambos e quilombos, uma vez que ambos os termos são empregados pela literatura e, em certos casos, com alguma diferença em sua finalidade. Usados desde as primeiras décadas da colonização,

\footnotetext{
${ }^{26}$ Expressão cunhada por Antenor Pacheco em seus estudos sobre o afro-indígena na Amazônia brasileira.
} 
os termos mocambos e quilombos foram designados como "acampamentos improvisados, utilizados para guerras ou mesmo apresamentos ${ }^{27}$ de escravizados", conforme Gomes (1997). No entanto, "mocambo ou mukambu, tanto em kimbundo como em kicongo (línguas da África Central), significava pau de fieria, tipo de suporte com forquilha utilizado para erguer choupanas nos acampamentos". ( $c f$. Gomes, 2015:11)

Segundo Stuart Schwartz (1987, apud Gomes 2015:12),

[...] ao longo do século XVIII - na documentação colonial - as comunidades de fugitivos foram denominadas ao mesmo tempo de mocambos, principalmente na Bahia, e de quilombos em Minas Gerais; e o termo quilombo apareceu em Pernambuco somente a partir de 1681. Assim, mocambos (estruturas para erguer casas) teriam se transformado em quilombos (acampamentos), e tais expressões africanas ganharam traduções atlânticas entre o Brasil e a África desde o século XVI.

O termo Mocambo poderia também ser relacionado ao tipo de moradia destinada a negros e índios alforriados, nos quais as condições de habitabilidade indicariam seu grupo social. Estas habitações marginalizadas poderiam, inclusive, estar inseridas às margens dos centros urbanos, uma vez que eram locais comumente empossados por negros e índios libertos. Diferentemente, o termo quilombo orienta a circunstância de expectativa de liberdade. Neste sentido, a sua organização toma como norte a luta pelos ideais sociais e de sobrevivência nos quais grupos de negros e índios fugitivos se juntariam a um mesmo fim. Além disso, estes quilombos não poderiam estar próximos aos centros urbanos como os mocambos, mas resguardados por locais distantes e de difícil acesso, uma vez que se encontravam em situação de fuga.

Apesar das sutilezas agregadas aos nomes mocambos e quilombos podemos considerar que a designação do termo africano "mocambos", referindo a agrupamentos de índios alforriados, é um indicativo do emparelhamento social havido entre negros e índios no período colonial. A situação descrita por Gomes (1997:70) demonstra a possibilidade do uso destes termos conforme destacado:

\footnotetext{
${ }^{27}$ Apresamentos: mesmo que captura
} 
Existiam também mocambos de índios por toda parte. [...] Em Portel, havia várias denúncias quanto ao abandono de 'serviço' por parte dos índios e que as povoações eram "compostas de mucambos que só aparecem quando querem". Investigações sobre fugas coletivas de índios em Soure revelaram "que todos seguem no caminho de Arauari, a donde se achão grandes mocambos". Da Vila de Monsarás, próximo ao rio Caracará "nos matos de Ponte de Pedra se achão amocambados 40 pessoas desta vila entre grandes e pequenos vivendo como no sertão sem missa nem confissão. "

Assim, a instauração de agrupamentos indígenas nos arredores da cidade para o interior se dava no mesmo molde dos negros, fomentando a designação africana mocambos para agrupamentos também de índios.

Os fatores que mais contribuíram para o aumento de mocambos e quilombos em terras marajoaras foram: a decadência de engenhos em meados do século XVIII, decorrente da desorganização e crise na lavoura com vista às drogas do $\operatorname{sertãao~}^{28}$; a expulsão dos missionários das terras marajoaras e o confisco de seus bens; a redistribuição de terras (sesmarias) que traria a dependência e submissão aos novos donos; e os acenos de liberdade, trazidos pela abolição da escravatura na Guiana Francesa $^{29}$ e mais à frente pelas ideias de Independência do Brasil (cf. Salles, 1971: 218).

Os mocambeiros, como eram chamados, se concentravam em áreas de floresta motivados pela grande extensão de terras de floresta e, em algumas ocasiões, incentivados pelas "sobras de terras" de fazenda no período de crise econômica ${ }^{30}$ ( $c f$. Acevedo Marin, 2009:214; Salles, 1971:7) das quais muitas vezes incidia em total abandono das terras de fazenda. Outro fator que os levavam a formar aldeias mais

\footnotetext{
28 A insistência da metrópole em descobrir drogas no sertão na região da Amazônia teve resultados frutíferos. A exploração da mão-de-obra africana e indígena coocorre com negros conduzidos à plantação e criação, ao mesmo tempo em que indígenas eram levados ao extrativismo. A descoberta das drogas do sertão - canela, baunilha, cravo, anil, raízes aromáticas, urucum, salsa, sementes oleaginosas, etc. provocou verdadeira corrida e sua intensa exploração a partir de meados do século XVIII, determina, em consequência, a primeira grande crise nas lavouras e modificando substancialmente o quadro econômico. ${ }^{29}$ Após a Revolução Francesa e a Declaração dos Direitos do Homem e do Cidadão foi abolida a escravidão na França em 4 de fevereiro de 1794 na Convenção Nacional. Contudo, Napoleão restabeleceu a escravidão em 20 maio de 1802. A abolição definitiva chegou em 27 de abril de 1848.

${ }^{30}$ Vide nota 24
} 
distantes, principalmente em Marajó, era a dificuldade de acesso decorrente da abundância de manguezais, o que os deixavam, de certo modo, um pouco mais a salvo de capturas. Como demonstra Gomes (1997:53) "era a própria imensidão da floresta a maior inimiga das autoridades e senhores de escravos e, portanto, amiga dos fugitivos".

O comportamento de se abrigarem no interior da floresta irá permanecer, também após o período de abolição da escravatura africana. Isso se deve por haver forte "resistência à integração e assimilação de valores culturais novos e aos novos direitos adquiridos" ( $c f$. Salles, 1971:135, grifo nosso). Este cenário reflete a situação das comunidades quilombolas hoje, nas quais se veem, em qualquer parte do Brasil, inseridas em regiões rurais e, algumas delas, situadas em pontos isolados e de difícil acesso.

No que diz respeito à história dos negros na ilha, Acevedo (2009:210) nos orienta que:

[...] pesquisadores de diversas áreas de conhecimento enfocam que os grupos de negros na ilha estabelecem uma relação entre os modos de existência social e cultural dos que se identificam como quilombolas com antigas formas de territorialização de escravos fugitivos, de indígenas e de trabalhadores livres.

Estes entre outros fatores fizeram do município de Salvaterra uma localidade que se distingue pelo número de comunidades aquilombadas, são elas: Siricari, Mangueiras, Salvá, Deus Ajude, Providência, Bacabal, Bairro Alto, Paixão, Boa Vista, Caldeirão, Campina, Santa Luzia e Pau Furado.

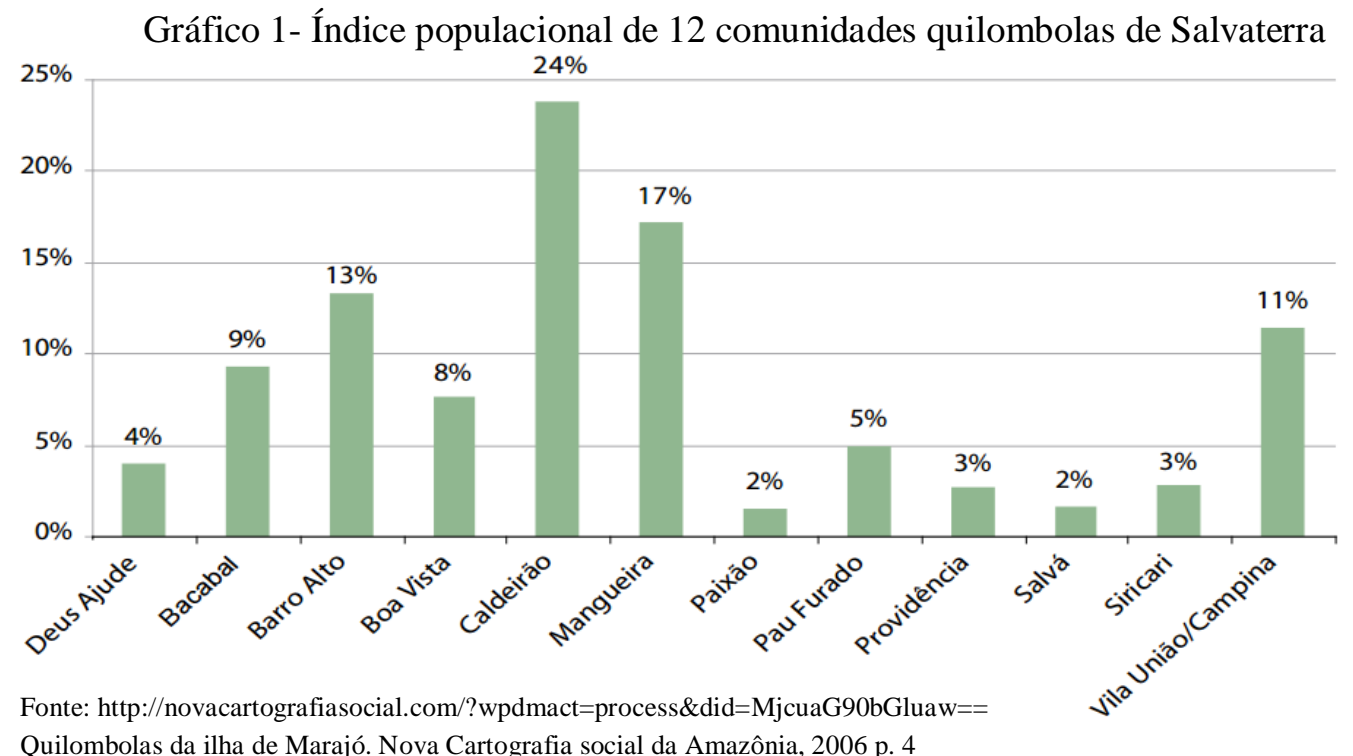
Quilombolas da ilha de Marajó. Nova Cartografia social da Amazônia, 2006 p. 4 
Conforme demonstrado (gráfico 1), Salvá e Paixão compõem as menores comunidades em número de população no município de Salvaterra. Esse fator decorre do difícil acesso em tempos de inverno, assim expresso pela comunidade, no qual se tem grandes volumes de chuva, impactando fortemente no modo de vida dessas comunidades. Isso tem provocado o êxodo para comunidades próximas, como a comunidade Mangueiras ou, em alguns casos, a fixação na cidade de Salvaterra, onde encontram recursos como escola, posto de saúde e comércio. Segundo moradores, o egresso a outras comunidades tem se tornado frequente. Casas abandonadas nas comunidades Salvá e Paixão vêm anunciar o desaparecimento destas num futuro bem próximo.

Já a comunidade Providência, que se iguala em número de habitantes à Siricari, está localizada bem próxima à comunidade Deus Ajude. Nesta comunidade há escola e uma casa no qual compartilham brinquedos e uma pequena biblioteca com a comunidade Providência.

A orientação sócio-histórica do município evidencia que essas comunidades podem revelar traços de base africana e indígena, tal como visto em Siricari e constatado em visita de avaliação nas comunidades de Salvá, Mangueiras, Deus Ajude e Providência. Destacamos entre estas, a comunidade de Mangueiras, pela disposição das casas formadas em círculo ${ }^{31} \mathrm{com}$ grande área de várzea central, indicando atributos físicos de aldeia, apesar de se tratar de uma comunidade quilombola.

\subsection{Marajó pré e pós-colônia}

A história de ocupação do arquipélago consta de cinco fases, sendo: Fase Ananatuba (a mais antiga), Fase Mangueiras, Fase Formigas, Fase Marajoara e Fase Aruã. A fase marajoara é a quarta fase de ocupação da ilha e, segundo Schaan (in Gallo, 2005:XXIX) a presença de cacicados marajoara data do período de 400 a 1100 d.C., quando sua trajetória entra em declínio. Não se sabe ao certo o que levou a redução dos índios Marajoara. Cogita-se ter havido aumento da população e exaustão de recursos das áreas mais produtivas, gerando frequentes conflitos internos. Há, também,

\footnotetext{
${ }^{31}$ imagem anexa
} 
indicações de que a mudança de clima pode ter afetado a produtividade de alimentos, já consolidada. Outros acreditam que a chegada dos povos Aruak à costa Norte de Marajó, vindos do Amapá por volta de 1300 d.C. tenha contribuído para a queda da sociedade Marajoara mediante guerras. Apesar disso, Schaan (in Gallo, 2005:XXVIII) afirma que:

Cacicados Marajoaras ainda viviam na Ilha quando os Portugueses aqui chegaram. Apesar das transformações ocorridas, que se refletem também em seus costumes, a cerâmica Marajoara ainda era produzida, mesmo em comunidades localizadas longe dos tesos ${ }^{32}$, e vários rituais ainda eram realizados.

A ilha recebeu em 1754 o nome mbará-yó 'Marajó', que em tupi significa barreira do mar. Seu conjunto de ilhas constitui a maior ilha fluvial do mundo com 49.606 Km2 e constitui uma das mais ricas regiões do País em termos de recursos hídricos e biológicos.

Conforme consta no Plano de Desenvolvimento Territorial Sustentável para o Arquipélago do Marajó (PDTSAM, 2007:16), o período de ocupação pré-colonial data próximo ao século $\mathrm{V}$, precedendo ao desenvolvimento das culturas amazônicas similares. A informação tem fundamento com base nos sítios arqueológicos (sambaquis) encontrados em Curralinho e Cachoeira do Arari nos quais datam cerca de 3 e 5 mil anos. Também, sítios descritos por Meggers e Evans ${ }^{33}$ como sítios dos Aruã proto-históricos, nos quais mostram ter esses povos chegados à ilha por volta do século XIV; e os sítios de contato (ou coloniais), onde se revelam o período de contato dos povos nativos com os europeus. (PDTSAM, 2007:17)

Relatos de Steward (1948:196) revelam que desde o período de ocupação colonial da ilha eram intensos os conflitos entre portugueses e índios da tribo Aruã $\tilde{a}^{34}$. Conforme o mesmo autor, as primeiras relações de contato entre os povos Aruã e o europeu datam de 1643 e, apesar da violenta hostilidade das relações, a causa do

32 Os índios Marajoaras levantavam suas casas sobre morros artificiais chamados de Tesos, construídos para proteger as casas de inundações.

${ }^{33}$ Somente a partir de 1940, com a chegada de Betty Meggers e Clifford Evans estudos na ilha de Marajó sobre a cerâmica Marajoara e o povo que a confeccionou ganharam impulso.

${ }^{34} \mathrm{O}$ município atual de Chaves abrigava a aldeia dos Aruans, mencionada pelos religiosos de Santo Antônio (Ensaio Corográfico sobre a província do Grão-Pará, p. 276) 
desaparecimento dos Aruã durante a primeira metade do século XIX em Marajó e ilhas vizinhas se deu em decorrência da revolta dos Cabanos em 1834-36.

Já há algum tempo a antropologia revela que devido à chegada dos colonizadores e missionários à ilha de Marajó, as formas de existência social e cultural dos grupos indígenas Nheengaíba ${ }^{35}$ e Aruã foram destruídas. (cf. Salles, 1971; Acevedo, 2009). Na historiografia de Marajó tratada por Salles (1971:125) consta que foi a "obra de catequese em Marajó funesta para o gentil". O estudioso esclarece que o intuito das missões religiosas consistia em instituir a escravidão indígena em função da fixação das primeiras fazendas missionárias na ilha. A atividade pastoril missionária contava com milhares de cabeças de gado vacum e cavalar, além de atividades agrícola e pastoril, fator que demandava grande número de escravos ( $c f$. Vianna,1904).

Conforme se lê nos dados do Ensaio Corográfico sobre a Província do Grão-Pará (2004:272) a economia do período colonial na ilha firmava-se, basicamente, da criação $^{36}$ (campos) e do extrativismo (florestas). As tarefas de criação e plantio eram bastante intensas para os indígenas, uma vez que não sabiam lidar com a função e sofriam severos castigos para executá-la. Conforme conta Miranda Neto ${ }^{37}$ (apud Salles, 1971), os castigos pela falta de habilidade para a criação e lavoura lhes valia, muitas vezes, a vida.

O período de conquistas hostis do solo marajoara, a perda da liberdade, da cultura, da língua, o contágio de doenças trazidas pelos brancos, os maus-tratos, a subserviência ao colonizador, e a anuência de um status de barbárie contra povos indígenas marajoaras, culminou na dizimação de numerosas tribos. Como revela ainda em Salles (1971:15) "não há dúvida que essa época assistiu a um dos maiores massacres da história dos contatos de raça do novo mundo".

O incremento de negros escravizados na ilha deu-se em função da alforria efetiva do indígena ${ }^{38}$ em 1751, aliado à destituição das terras ocupadas pela Companhia

\footnotetext{
35 Nheengaíba (língua ruim): denominação dada a diversos grupos indígenas que habitavam a ilha de Marajó

${ }^{36}$ Gado vacum e cavalar transmutado de Belém em 1702, trazidos de Cabo Verde em 1644. (Ensaio Corográfico sobre a província do Grão-Pará, p.272)

${ }^{37}$ Miranda Neto. A foz do Rio Mar, 1968, p.89 e 97

${ }^{38}$ Para saber mais ver Salles, 1971 - Parte 1 - 2. A política escravista do século XVIII
} 
de Jesus ${ }^{39}$ em 1758, resultando sobremaneira o tráfico negreiro em toda a região do Grão-Pará e Maranhão.

Tabela 1: População escrava em Marajó - 1832 (in Salles, 1971:126)

\begin{tabular}{lc|} 
Município & População negra escrava \\
\hline Cachoeira do Arari & 531 \\
\hline Chaves & 446 \\
\hline Monsarás* & 249 \\
\hline Monforte* & 124 \\
\hline Muaná & 503 \\
\hline Total da população escrava negra & $\mathbf{1 . 8 5 3}$ \\
* Os antigos municípios de Monsarás e Monforte (hoje Joanes) são distritos do \\
município de Salvaterra.
\end{tabular}

As amostras quantitativas de negros demonstradas por Baena (apud Salles, 1971:125) apontam para o crescimento da população negra escrava em Marajó entre os anos de 1832 e 1848.

Nos cálculos de José Veríssimo, em sua obra Estudos Brasileiros, no ano de 1885 (apud Salles, 1971) já se observava que o negro constituía a maior parcela da população da ilha. É importante destacar que no início do século XIX a ilha apresentava um quantitativo de 226 fazendas, importando em vasta mão-de-obra escrava.

Tabela 2: População escrava em Marajó - 1848 (in Salles, 1971:105)

\begin{tabular}{|l|c|c|c|}
\hline Município & Adultos & Menores & Total \\
\hline Boa Vista & 403 & 411 & 814 \\
\hline Muaná & 345 & 179 & 524 \\
\hline Cachoeira do Arari & 485 & 223 & 708 \\
\hline Ponta de Pedras & 152 & 94 & 246 \\
\hline Monsarás & 134 & 99 & 233 \\
\hline Monforte & 38 & 9 & 32 \\
\hline Soure & 62 & 54 & 116 \\
\hline Chaves & 350 & 279 & 629 \\
\hline
\end{tabular}

\footnotetext{
${ }^{39}$ Para saber mais ver: Annais da Bibliotheca e Archivo Publico do Pará (1904) capítulo "Os Contemplados".
} 


\begin{tabular}{|l|c|c|c|}
\hline Gurupá & 145 & 93 & 238 \\
\hline Melgaço & 154 & 153 & 307 \\
\hline Portel & 65 & 23 & 88 \\
\hline Total da população escrava negra & & 3.935 \\
\hline
\end{tabular}

A maciça presença do negro escravo em Marajó, acrescida da proximidade relativa entre os municípios da ilha ( $c f$. Mapa 3 - Mesorregião Geográfica do Marajó), contribuiu para um processo migratório de comércio interno e, igualmente, de fugas, como aponta Acevedo (in NAEA, 2005). Podemos crer que esses movimentos migratórios eram constructos de uma miscigenação envolvendo povos indígenas, negros e mestiços, estabelecendo pactos sociais de luta e nova configuração de espaços afins. Um pouco além dos dados estáticos da demografia histórica, Mattos e Silva (2000:1127) tece o seguinte comentário:

[Em] Uma interpretação para a generalizada difusão da língua portuguesa no território brasileiro. O objetivo desse estudo foi o de defender o ponto de vista de que o português se generalizou na amplidão do território do Brasil pela 'voz' dos africanos e afrodescendentes. Discordo, portanto, de Serafim da Silva Neto, Gladstone Chaves de Melo e de Sílvio Elia, que defenderam a inexorável vitória da língua portuguesa por causa da 'superioridade cultural do colonizador'.

A mestiçagem no norte do Brasil envolvendo brancos, índios e negros recebeu denominação para cada tipo de mestiçagem ${ }^{40}$. Conforme Veríssimo (1887:299) havia curiboca, mameluco, tapuio, mulato, cafuzo distinguindo as mesclas conforme convinha à sociedade. A essa configuração o mesmo autor explica:

A essa população que habita as margens do grande rio e dos seus numerosos affluentes, vivendo a nossa vida, contribuindo para a nossa receita, trabalhando nas nossas industrias, e que não é nem o índio puro, o brazilio-guarani, nem o seu descendente em cruzamento com o

40 Curibóca (branco+índio); Tapuio/Mameluco (curiboca+branco); Mulato (negro+branco); Cafuzo (negro+índio) Ver. Veríssimo, 1887:297-299. 
branco, o mameluco, é que, parece-me, cabe o nome tapuia. Sabe-se hoje que na língua tupi-guarani, a mais espalhada e geral entre os índios do Brazil, a palavra tapuio (tapyia, y igual ao $u$ francez, porém guttural) era, como o bárbaro dos romanos, uma denominação genérica do despreso que se davam entre si os indivíduos de outras tribos, e que naquela língua significa não só o hostil, o inimigo, mas o escravo. Os mamelucos, aproximando-se mais e mais da sociedade de seus pais, os brancos, começariam a crear pelo índio aldeado, escravizado, vendido, o mesmo despreso que na vida selvagem as tribos reciprocamente se votavam, e a tratal-os pelos mesmo nome que entre ellas exprimia esse despreso ou- e talvez seja melhor escolhida a expressão - essa hostilidade. Assim ella passou á nossa sociedade, onde designa todo o individuo descendente de índio e é muitas vezes empregado com menosprezo, a modo de affronta."

Os fatores de miscigenação étnica ocorrido nos tempos coloniais determinavam parâmetros sociais que colocavam o negro, o índio e o mestiço à margem da sociedade. Essa condição culminou para a proliferação de agrupamentos de mocambos e quilombos miscigenados com a inclusão também de libertos.

Muitas comunidades marajoaras de hoje nasceram desses agrupamentos edificados ainda no período colonial. Apesar das circunstâncias sociais desfavoráveis, o intercâmbio das culturas africana e indígena constitui um rico universo de sabedorias nos quais índios, negros e mestiços recriaram suas histórias mesclando práticas de trabalho, crenças, matrizes díspares que particularizam as comunidades quilombolas da Amazônia marajoara. No entender de Pacheco (2011:49)

[...] no século XVIII índios e negros recriaram espaços, transgrediram normas de trabalho e recusaram-se ao silenciamento cultural pela imposição de grupos dominantes, no séc. XIX novas 'zonas de contato' continuaram sendo entalhadas. Práticas de trabalho [...] sabedorias ancestrais nativas ou diásporas $[\ldots]$ ritualidades $[\ldots]$ caruanas, orixás e santos do catolicismo popular.

Somada as circunstâncias determinantes para a formação desses grupos étnicos quilombos e mocambos estabeleceram, ao longo da história, um território marajoara singular marcado pelas identidades africana e indígena, símbolo evidente em nossa 
cultura brasileira. São estes aspectos tão evidentes em Marajó e, sobretudo, tendo confirmado étnico e historicamente tais características na comunidade Siricari que faz desse local um rico ambiente de investigação linguística.

Neste sentido, abordaremos no capítulo seguinte pressupostos etnolinguísticos que nos conduzem para a hipótese de haver, dentro de algumas variações do português falado em Siricari, vestígios que nos orientam para situações linguísticas condizentes à proposta de um português afro-indígena. 


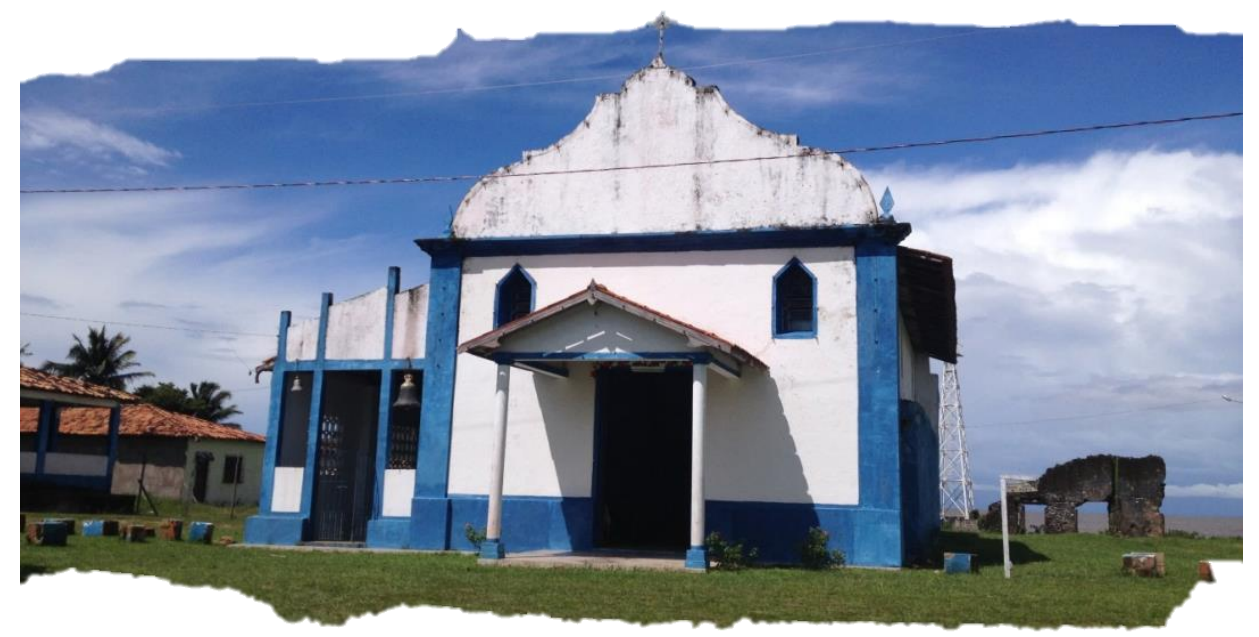

Figura 3 - Igreja N. Senhora do Rosário (reconstrução)

Encontraram o negro solidário com o índio nas vicissitudes sociais.

Não importa se negro autêntico ou se índio autêntico. O passaporte da autenticidade, naquele contexto, já havia perdido tôda ou quase tôda importância. Ambos despojados dos seus padrões culturais, quebrados definitivamente, amalgamados numa nova cultura, resultante da fusão de três componentes étnicos.

Wagley \& Galvão, apud Salles, 1971:67 


\section{Capítulo 2: A Etnolinguística e o Português Afro-indígena}

\subsection{Remanescente de contato linguístico}

As relações de contato entre indígenas e africanos na Amazônia marajoara datam do período de sua ocupação já em meados do século XVII. O resultado deste contato está inscrito na composição cultural da arte marajoara, nas lendas, nas cerâmicas encontradas em escavações, nas crenças e ritos religiosos, nas narrativas orais e literárias, no tipo de alimentação, nas práticas de caça, pesca, extrativismo, entre outros hábitos diários indicativos deste intercâmbio cultural afro-indígena.

Mas não houve apenas relações de trocas, empréstimos e sociabilidades estabelecidas entre povos indígenas e europeus nos primeiros períodos da sociedade colonial. Durante muito tempo foi também espaço compartilhado por diversas línguas e esse fator culminou na adoção de uma língua hegemônica de relações interétnicas. Datada em 1616 a edificação do Forte do Presépio, hoje cidade de Belém, designou a instalação dos chamados descimentos e aldeias de repartição nos quais missionários eram responsáveis pela domesticação do selvagem, termo este empregado aos indígenas. O trabalho desenvolvido pelos religiosos consistia em preparar os índios capturados, dos mais diversos grupos linguísticos, para o tralhado forçado e, portanto, deveriam também ensiná-los a se comunicar em tupinambá. Isso levou à expansão do tupinambá como língua franca na Amazônia, independentemente de haver situações de bilinguismo em outras línguas indígenas ou europeia, o tupinambá alcançou grandes proporções interlocutórias e passou a ser chamada Língua Geral Brasílica (doravante LGB).

\footnotetext{
A língua tupinambá acabou [...] exercendo a função inicial de língua de comunicação entre os portugueses e os diferentes povos tupis da região, tornando-se ainda, paulatinamente, a língua materna dos mestiços, filhos de pais europeus e mães indígenas. No processo histórico de sua constituição e expansão, essa língua passou a ser conhecida no período colonial como Língua Geral. (Freire, 2003:51)
}

A LGB tomou dimensões de língua oficial no Estado do Maranhão e Grão-Pará no ano de 1689 (cf. Bessa Freire, 2004:61) e o incentivo ao uso dessa língua fazia parte da política colonialista de Portugal nos 30 anos que se seguiram. No entanto, o intenso 
contato da língua tupinambá ou LGB com outras línguas indígenas e europeias contribuiu para que o "tupinambá puro ${ }^{41 "}$ tomasse características distintas. Segundo Borges \& Nunes (1998 apud Freire 2004:66) uma variante seria o tupinambá colonial, exclusivamente de uso oral, falado por grupos linguisticamente heterogêneos; e a outra, o tupinambá tribal, cujos falantes eram índios tupinambás e missionários que a usavam em práticas religiosas orais e escritas. Em meados do século XVIII, o desaparecimento da variante tribal usada nos catecismos consolidou a expansão da variante denominada como tupinambá colonial, recebendo o tratamento de Língua Geral Brasílica, vindo a ser chamada Língua Geral Amazônica por Aryon Rodrigues (1996) o qual diferencia a língua geral de matriz tupinambá (Maranhão e Pará) da língua geral de matriz tupi (São Paulo).

Vale apontar o que ensina Aryon Rodrigues (1996:10) sobre o que ele chamou "produto de contato" ocorrido na sociedade colonial:

Não houve, em nenhum momento, interrupção na transmissão dessas línguas [indígenas e europeias], isto é, não ocorreu mudança de língua (language shift) nos descendentes mestiços dos europeus e das índias tupi-guaranis: os primeiros pais europeus aprenderam a língua indígena como segunda língua, tendo-se tornado bilíngues; parte das mães indígenas pode ter aprendido a língua europeia como segunda língua, mas seus filhos ou ficaram monolíngues na língua indígena (que pouco a pouco foi-se transformando na língua geral) ou aprenderam a língua europeia como segunda língua.

Apesar de o autor não se referir exclusivamente à região amazônica, mas às línguas gerais sul-americanas: Língua Geral Amazônica (LGA), Língua Geral Paulista (LGP) e o Guarani crioulo, (GNC), presente em território paraguaio e argentino, ressaltamos que, igualmente, na região amazônica não houve interrupção na transmissão da LGA mesmo diante do intenso contato entre diferentes grupos indígenas e europeus.

\footnotetext{
41 A referência que se faz ao termo "tupinambá puro" significa a língua falada nas aldeias dos povos tupinambás antes de qualquer contato com as línguas europeias. Isso não quer dizer que está totalmente isenta de influências de contato com outras línguas indígenas nativas no território brasileiro antes do período de colonização. Ou mesmo não se imprime aqui a questão se houve ou não alguma língua indígena que viesse contribuir para variantes do tupinambá antes da interação com as línguas europeias.
} 
Como aponta Freire (2002:16), enquanto a região do Grão-Pará e Maranhão estava separada do Brasil a LGA permaneceu como majoritária na população regional. Então, até meados do século XVIII a língua geral amazônica fazia parte do contexto social, chegando a ter um status de língua de relativo prestígio falada por índios, negros e europeus. Em contrapartida, a língua portuguesa, neste mesmo período setecentista, era empregada apenas em trâmites administrativos e era falada comumente pelos europeus e auxiliares imediatos.

É também no século XVIII que se intensifica a chegada de africanos escravizados na região do Grão-Pará e Maranhão. O contato com índios nas mais diversas situações sociais determina mais outra situação de multilinguísmo, apesar de haver relatos de que se "ouviu negros recém-chegados da Costa da África falando desembaraçadamente a sobredita língua geral" ( $c f$. Freire, 2004:65).

Embora estudos tenham preferido apontar para uma relação de bilinguismo entre a LGA e o português europeu em função das práticas sociais, interesse político e econômico da época, não se pode negar uma situação de multilinguísmo nos primeiros três séculos do Brasil colonial. Esse fato nos leva a indagar quais e em que medida ocorreram influências de outras línguas atingindo a língua de comunicação (LGA) e a língua da administração (português europeu).

As variações linguísticas ocorridas na língua dominante vivida em situação de contato podem operar, do ponto de vista do substrato, em dois planos: da fala individual e da fala coletiva, conforme ensinam Moore, Facundes \& Pires (1990 apud Freire, 2004:64)

Individual: o substrato constitui o conjunto de transferências linguísticas de natureza sistêmica, a partir da primeira língua, ou língua materna, no processo de aprendizagem de uma segunda língua.

Coletivo: o substrato constitui o conjunto de marcas que uma língua, quase sempre extinta, deixa sobre a outra língua. Trata-se da influência nos aspectos fonológicos e sintáticos da língua perdida sobre a língua imposta, que só se estabilizam quando afetam a comunidade de fala em gerações sucessivas.

Considerando o processo histórico de formação do português brasileiro, o contato linguístico ocorrido na sociedade colonial pode ter produzido não apenas 
variações do português brasileiro em relação ao português europeu, mas determinado traços dialetais característicos de falares indígenas e africanos, desenhando modos particulares na fala de comunidades rurais.

$\mathrm{Na}$ perspectiva do português afro-brasilerio, Lucchesi, Baxter \& Ribeiro (2009:93) defendem construções gramaticais passíveis de situações de contato ocorridas no passado e, considerada por eles como características associadas à crioulização ${ }^{42}$. No entanto, apesar de reconhecermos a importância dos estudos afro-brasileiros e termos, em um primeiro momento, buscado bases teóricas para discussão do português afroindígena, argumentamos sobre a legitimidade de algumas variações se tratarem apenas influências de línguas africanas. Seguem algumas dessas construções:

(1) ausência de preposição em estruturas nominais: folha mandioca por folha de mandioca;

(2) ausência do verbo copulativo: esse aí neto de Casimiro por esse aí é neto de Casimiro;

(3) orações encaixadas sem complementizador: ele disse a irmã dele veio do Rio, por ele disse que a irmã dele veio do Rio;

(4) negação verbal com sujeito marcado negativamente: nenhum descarado num tá trabaiano não;

(5) estruturas de duplo objeto com inversão na ordem dos complementos verbais e supressão da preposição de dativo: Dá pessoá muita lembrança, minha fia! por Dá muitas lembranças ao pessoal, minha filha!

(6) uso de formas do presente para indicar ações e estados situados no passado: meu pai é de cativeiro, com o sentido de 'meu pai era escravo'.

\footnotetext{
${ }^{42}$ Segundo Lagorio \& Freire (2014:583), por definição, língua crioula implica na formação de uma língua mista, cujo léxico é proveniente da língua dominante, mas as características sistêmicas são da língua dominada.
} 
Conforme demonstrado, as características apontadas pelos autores evidenciam variações de um português falado em comunidades reconhecidamente de descendência africana. Todavia, em se tratando da região do Pará, no qual concentramos nossa investigação, entendemos que a demora na adoção da língua portuguesa em solo paraense ( $c f$. Freire 2004:56) pode ser considerada um dos fatores para a manutenção de fragmentos linguísticos da Língua Geral Amazônica (LGA) tão evidentemente tratada na história de constituição daquela região. A esse respeito, a contribuição de Freire esclarece que:

Existem evidências históricas de que a adesão do Grão-Pará à independência do Brasil, em agosto de 1823, incorporou ao novo Estado um expressivo contingente populacional que, em sua maioria, não falava o português como língua materna, situação que se prolonga por algumas décadas (2004:56).

Deste modo, temos a convicção de que muitas das variações do português presentes na região do Pará, sobretudo na comunidade Siricari, tratam-se de influências da língua geral amazônica, bem como de línguas africanas mantidas ao longo das relações histórica entre povos indígenas e africano. Neste sentido, estudos de Freire (2002; 2004), Rodrigues (1983); Salles (1971) têm nos levado ao entendimento de que quatro são os fatores preponderantes para a manutenção de possíveis marcas de substrato da língua geral amazônica no português falado da região do Pará: (i) o uso da língua geral ao longo de todo o período colonial como língua de relação social, perdurando de certo modo, até após a independência do Brasil (1822); (ii) durante longo tempo, o sistema de trabalho em lavouras e a criação exigiam o mínimo de comunicação entre os diferentes agentes de produção e, quando se fazia necessária, a LGA era a língua mais comumente usada pelos trabalhadores e donos de propriedades; (iii) nas práticas religiosas impetradas pela catequese jesuítica, a práxis era o uso da LGA e não o português e; (iv) enquanto a língua portuguesa já se mostrava hegemônica em grande parte do litoral brasileiro, continuava minoritária na Amazônia. Vale ressaltar o comentário de Freire (2004:122) no qual assinala que somente "na segunda metade do século XIX o português passou a ser a língua falada pela maioria da população amazônica".

Não obstante a imposição de um monolinguísmo português, a língua geral amazônica falada pelos brancos, negros e índios tem em sua trama também a língua 
negra trazida pelas nações africanas, conforme demonstra Mattoso Câmara (1975:30$31)$ :

[...] contingentes das mais variadas nações negras [...] tinham necessariamente de criar uma língua de compromisso para intercurso. [...] o desenvolvimento de um português crioulo [...] uniu entre si os negros das mais diversas proveniências. Também tudo indica que se adaptaram com relativa facilidade ao uso da língua geral indígena, dando-lhe ainda mais estímulo e expansão.

Apesar de não apontar de que língua geral indígena o autor se refere, acreditamos que, em se tratando da região norte, notadamente a alusão é à LGA, reconhecidamente como a língua geral indígena falada naquela região. Importa que, nas palavras de Mattoso Câmara, é possível reconhecer desdobramentos linguísticos no dialeto português brasileiro também provocados pelas línguas naturais indígena e africana.

Em que pese a discussão sobre as variações do português brasileiro, procuramos não contestar, mas seguir ao lado da rica contribuição dos estudos afro-brasileiro sobre a influência das línguas africanas no português brasileiro. Isso, porque não há como discorrermos de um português afro-indígena, desconsiderando o longo caminho de pesquisas e as pertinentes informações trazidas por esses estudos. A exemplo dessa importância, estudos de Petter (2007:9) nos chama a atenção para os diversos resultados semelhantes entre o português falado na África (área não crioula) com as variações do português brasileiro, destacando afinidades nos níveis fonológico, lexical e morfossintático.

É neste sentido que enfatizamos ser algumas variedades do português brasileiro, presentes em contextos rurais, um reflexo pluriétnico provocado pelo contato do português com as línguas indígenas e africanas. É fato de que o efeito desse contato repercute nas estruturas do português brasileiro, de modo que algumas dessas estruturas podem aparecer atualmente, conforme Lucchesi (in Roncarati \& Abraçado, 2003:278), dispostas como norma culta e, em outros casos, se restringem ao português popular.

Segundo Orlandi \& Souza (1988:32-38) "durante muito tempo negou-se a influência de fato do tupi sobre o português. Ou melhor, nega-se a historicidade, primeiramente para o próprio tupi e, depois para a evolução do contato”. Entretanto, 
estas autoras propõem o estudo da linguagem a partir da perspectiva discursiva, demonstrando que "há, atrás de vocábulos, toda uma história de contato e de processos de significação que são postos em movimento". Diante dessas conjecturas, as relações de contato na região paraense de Marajó, historicamente nos autorizam a ratificar a hipótese de Oliveira et alii (2015:8) sobre um continuum relativo às variedades do português popular brasileiro. 


\subsection{A herança de um preconceito linguístico}

Segundo Padre Antônio Vieira apud Freire (2003:79), “a língua tem avesso e direito; o direito é como nós a falamos, e o avesso como a falam os naturais [...] meiaslínguas, porque eram meio portuguesas e meio de todas as outras nações”. A declaração de Padre Antônio Vieira não surpreende pela afirmação pejorativa sobre o modo de falar regional. Naquela época, a visão equivocada mantida pela concepção purista da linguagem contribuiu para encobrir constantes fenômenos da linguística, provocados pelas relações de contato entre o branco, o índio e o negro. Um erro crasso sobre a riqueza linguística empreendida pelo contato de diferentes povos, línguas e cultura.

Esse tipo de concepção purista da língua, onde o "avesso" é considerado "meialíngua", deixou um rastro de preconceito linguístico descarregado, sobretudo, sob a fala rural. É imprescindível que haja uma compreensão legítima da trajetória linguística pelos quais o português brasileiro se constituiu ao longo de sua ocupação em território brasileiro. Não há que se considerar um país de tanta diversidade linguística, seja de línguas nativas, e também as línguas importadas, preservar um dialeto imutável. Aliás, podemos crer que a grandeza linguística presente no português brasileiro reflete a miscigenação étnica que subsiste na formação do Brasil. Deste modo, entendemos a relevância de pesquisas que venham demonstrar aspectos linguísticos que revelem eventos ligados ao contato linguístico, mesmo ocorridos no passado, mas que contribuam para desmitificar esse preconceito herdado e mantido tão erroneamente por nossa sociedade.

Ainda hoje estudos linguísticos na região da Amazônia, berço de evidentes relações de contato, são incipientes no que tange a relação entre língua de índio, língua de negro e o português europeu. Mudanças substanciais ocorreram no considerado português colonial, no qual reconhecidamente resíduos de línguas indígenas e africanas participaram ativamente para a formação do português brasileiro. Empréstimos lexicais foram os que mais se sobressaíram, entretanto, a língua aprendida por oitiva abre precedente, por exemplo, para variações de ordem fonológica e a cristalização desta, reflete na escrita e por assim vai. Também, além dos planos sintático e morfológico, a orientação aponta para investigações no eixo pragmático da língua. Neste viés, é imprescindível adentrar na cultura de um povo, de uma sociedade para se distinguir elementos linguísticos próprios. 
Da babel amazônica, projetada por Orlandi \& Souza (1988:38), ensinam que "estamos presos ao nosso português como língua imaginária, construída por esquemas gramaticais rígidos, dos quais excluímos, tornamos invisíveis, qualquer contato com as línguas indígenas que vá além de vocábulos”. Estas autoras mostram que concepções dadas como brasileirismos nada mais são que vestígios de língua indígena na língua do colonizador. A exemplo disso, elas discorrem sobre o sufixo tupi rana, que significa parecido, como se fosse. Segundo Gallo (1997:108) esse sufixo era comumente empregado na língua tupi em nomes de animais e plantas como: moçurana, cobra preta parecida ao moçum (m-cym: o que faz deslizar); jacareana, de jacaré; piquiarana, de piquiá (pi-quyá).

O processo sufixal utilizado para nomes em tupi garante produtivo processo de derivação morfológica na língua portuguesa. Ele motiva infinitas formas modalizadas como em: sagarana (como se fosse saga), cajarana (como se fosse cajá), tataranha (como se fosse fogo) e, conforme exemplificado por Orlandi \& Souza (1988) "netarana" (como se fosse neta) escutado em Belém. Isso atesta que o mesmo processo de modalização de nome característico do tupi é empregado também no português.

Outra amostra linguística que incide diretamente sobre o modo de falar rural são documentos oficiais que sinalizam para eventos relativos ao contato linguístico, como apresentado por Freire (2003:83). Trata-se de um documento redigido por um tenentecomandante de Soure ao presidente da Província do Pará:

Participu a V. Exa. q. tenho a honra de Remeter novi Buis para despuzisons de V. Exa. Nom repari não ter hido amais tempu o Gado foi por nom terin xegado amais tempu e tãoben non aver enbargasons soficiente: Rogo a V. Exa. Q. dalguma manera nois quera quadejovar com a portesão de V. Exa. em nois enviar monisão tantu de musquitaria comum de hartilharia cendo para pessa calibri I e 3, pôs nois estamo mointo ariscado nisti pontusingondo as nutiçia q. temus dus nósos ennimigus. Tãoben rogo a V. Exa. nóis quera háremediar com algun çal e mesmo harmamentu q estamos mointos faltos deles. Ex.mo. Sr.,nõn ce quera isquecer do pididu q. o Juis de Pais d'esta Vila feiz para os Povos q. V.Exa. bem sienti ade estar. O mais V. Exa. verá no Pidido jontu q. faz obegeto tãoben desti ufisio. Deos Garde V. Exa. pur moitos anus. Soures 13 de Dezembru de 1853. Ilmo. Ex.mo. Sr. Edoardo Francisco Nugera Amgilin Prisidenti. 
Por se tratar de um documento oficial, entendemos que a redação procurou seguir padrões normativos. Ocorre que, muitos oficiais cabanos eram índios, tapuias, negros, caboclos e variados tipos de mestiços provenientes de diferentes horizontes linguísticos ( $c f$. Freire, 2003).

Outro documento oficial transcrito pelo Centro de Memória da Amazônia apresenta a ata de um depoimento acerca da rebelião dos cabanos em 7 de janeiro de 1835, demonstrando na modalidade escrita vacilações da ortografia, segmentação das palavras, entre outros elementos linguísticos que podem estar relacionados com a reflexo da constituição de contato linguístico daquela época.

\section{$4^{\mathrm{a}}$ Testem $^{\mathrm{a}}$}

Romoaldo José de Siqueira Natoral do Pará idade cincoenta edois annos cazado Morador no Rio Jenipauba testemunha jorada aos santos evangelhos em o livro delis em que poz a sua mão direita e prometeu dizer verdade do que sobeci e lhe fose perguntado e de custome disse nada.

Sendo the preguntado se çabia quem forão os aotoriz principais cabeça dos Rebeldes que asaltarão a cidade a fim de matarem as aotoridades da Província disse que sabe por ser publico e notório que Felis Antonio Clemente Malcher forão os que fizerão a primeira reonião em caza do ditto Malcher donde o $\mathrm{Snr}^{\circ}$ Prezidente Lobo os mando bater e forão destrosados sendo presos o ditto Malcher ficando Vinagre e Edoardo e seus Irmoens quidando na pertenc (documento deteriorado) que pertendião (documento deteriorado) sefetou dia sete de janeiro de mil oito sentos e trinta e cinco entrarão na cidade huma porção de homenz comandados pello João Miguel de Souza Leal Aranha, Francisco Pedro Vinagre Antonio Pedro Vinagre e Edoardo e seus Irmoens e assassinarão as aotoridades e alguns portoguezes negociantes das partes do porto do Sal.

Disse mais que sabe por ser poblico inotorio que depois de se apocarem da cidade e mandarão buscar a Malcher que se achava preso na barra e o fizerão logo Prezidente da Província e Vinagre 
comandante de Armas e otroz o cargo que ocuparão. (Centro de Memória da Amazônia - sub-fundo Crime; Juízo de Pás, cx: 01, ano 1837)

Os registros escritos em documentos oficiais em meados do século XIX ratifica a composição de um português fortemente marcado pela relação de contato vivida num passado ainda recente linguisticamente.

Algumas marcas de registro oral deixadas na documentação escrita são notadas comumente em regiões rurais, especialmente estudos que tratam de variações linguísticas do português falado em comunidades quilombolas. Em Siricari, por exemplo, verificamos a incidência de marca de plural em um único elemento do sintagma nominal, tal como demonstrado no ofício: "enbargasons soficiente / as nutiçia", ou mesmo fenômenos fonéticos como em "nois / tãoben / nom e nõn"/ preguntado / forão / pertendião.

A língua geral, incluindo a paulista, foi considerada por Couto de Magalhães (1876, apud Freire, 2003:103) como uma das línguas "que ocupam maior superfície da terra, senão a maior”. Em algumas áreas chegou a ser considerada parte do currículo obrigatório de escolas. Mas, em meados do século XVIII a política colonial proíbe o uso da língua geral e obriga em todos os meios sociais o uso da língua portuguesa.

Apesar da arbitrariedade, em áreas rurais da região do Grão-Pará a LGA permanece como majoritária até perder força a partir da adesão tardia (1823) à Independência do Brasil. A hegemonia da língua portuguesa nas margens do rio Amazonas vai ocorrer apenas em meados do século XIX, limitando o uso da língua geral tão somente nas regiões do alto rio Negro ( $c f$. Freire, 2004:17).

O preconceito atribuído à "meia-língua" de Padre Antônio Vieira persiste ainda nos tempos atuais, demonstrando a incapacidade de se pensar a trajetória da língua portuguesa e sua evolução do ponto de vista do contato. É evidente que o português brasileiro tenha recebido influências da LGA em todos os aspectos linguísticos. Legitimamente, a Amazônia possuiu duas línguas oficiais: a LGA, ativa durante três séculos a contar da colonização; e o português "brasileiro", hegemônico próximo a um século e meio até aqui. Portanto, a "meia-língua" nada mais é que uma rica herança linguística historicamente marcada pelo contato entre o português europeu e a língua geral amazônica. Não há fronteiras em uma língua, sua extensão é o horizonte 
linguístico do falante no qual a dimensiona a seu jeito, ao modo de sua cultura, ao belprazer de seu pensamento.

\subsection{Português Afro-Indígena: Parâmetros}

As primeiras discussões sobre a existência de uma variedade vernacular rural do português brasileiro $L_{1}$ falada por comunidades envoltas em miscigenação africana e indígena surgiram com Oliveira \& Praça (2013). As autoras argumentam que em uma comunidade historicamente constituída por traços africano e indígena estariam manifestas interferências não apenas culturais, mas também linguísticas.

Designado como Português Afro-Indígena, os estudos em comunidades quilombolas do norte do Brasil inauguram importante etapa para pesquisas envolvendo variantes do português em áreas rurais. A hipótese trazida pelas autoras no estudo Para um cotejo etnolinguístico entre comunidades afro-indígenas - Jurussaca (PA) e Tremenbé (CE): primeiras aproximações (Oliveira \& Praça, 2013) abre caminho para outras investigações. Surgiram, então, pesquisas abrangendo o português do Libolo (AF) e Angola (AF) em cotejo com a perspectiva do Português Afro-Indígena de Jurussaca ( $c f$. Figueiredo \& Oliveira, 2013); além de outras importantes contribuições como: O português afro-indígena de Jurussaca/PA: revisitando a descrição do sistema pronominal pessoal da comunidade a partir da textualidade (Silva, 2014); A sintaxe pronominal na variedade afro-indígena de Jurussaca: uma contribuição para o quadro da pronominalização do português falado no Brasil (Campos, 2014); O conceito de português afro-indígena e a comunidade de Jurussaca (Oliveira et alii, 2015).

Estes estudos tiveram como propósito investigar as variedades do português vernacular brasileiro sob a perspectiva do Português Afro-Indígena, denominado por Oliveira et alii (2015:8) como sendo:

Uma variedade vernacular rural de português brasileiro $L_{1}$ falada por comunidade envoltas em miscigenação afro-indígena, mas que selecionam politicamente o termo "afro" ou "indígena". Exemplificam-se as comunidades de Jurussaca/PA (autoidentificada como comunidade quilombola, logo "afro") e AlmofalaTremembé/CE (autoidentificada como comunidade indígena, mas não "afro"). 
Além da característica de "português $\mathrm{L}_{1}$ ", o Português Afro-Indígena atesta as seguintes outras características: (i) festas de sincretismo religioso que se subdividem em dois subtipos: (a) subtipo "ladainhas" (como em "Jurussaca"); (b) subtipo “torém/torén" (como em “Almofala/Tremembé”); (ii) linguagens cerimoniais (ex.: ladainhas; a música cantada na dança do torém/torén).

A variedade de português afro-indígena compartilha com as variedades de português afro-brasileira e indígena a característica de localizarem-se ao extremo [+ marcado] do continuum dialetal de português; difere, no entanto, da variedade indígena, por ser esta $\mathrm{L}_{2}$ por definição, e da afro-brasileira, por esta variedade não contemplar o traço de miscigenação indígena.

Uma das questões tratadas na definição que merece comentar são os ambientes de "rituais de sincretismo religioso". Nesses locais é possível verificar palavras ou expressões preservadas no tempo das quais podem revelar pistas linguísticas de uma relação de contato havida no passado. Os estudos do Português Afro-Indígena mostram que a conservação e a permanência desses espaços colaboram para que elementos significativos relacionados ao substrato de línguas decorrente do contato venham à tona. Conforme Oliveira et alii (2015:7),

No português afro-indígena, como em Jurussaca e em Almofala/Tremembé, as "linguagens cerimoniais" - atadas às "festas de sincretismo religioso" (tipos "ladainhas" e tipos "torém") - tratamse de variedades 'híbridas' que podem apresentar palavras do português quinhentista, palavras do latim, palavras do português moderno, palavras de línguas africanas, palavras de línguas indígenas e ainda serem influenciadas pelo ambiente ecolinguístico da comunidade (como o que se atesta nas cerimônias das viúvas em Ano Bom.)

Assim, apesar de a literatura indicar um universo religioso na Amazônia submerso nas religiões de origem africana, indígena e europeia ( $c f$. Maués, 2005; Pacheco, 2010) é possível constatar uma propagação dos princípios evangélicos em algumas comunidades amazônicas como em Siricari. Nesta comunidade a incursão evangélica, de certo modo, vem inibindo a continuidade desses ambientes de 
sincretismo, consistindo na perda de costumes e tradições impregnadas de saberes imateriais amazônicos. O abandono ao costume das rezas em latim, até pouco tempo visível em Siricari, hoje pouco se observa o trabalho das benzedeiras e, quando há reza, nunca são feitas em latim. Notadamente, um empobrecimento do patrimônio cultural que distingue as comunidades amazônicas na sua inter-relação com estratos africanos e indígenas.

Outro ponto importante na perspectiva do Português Afro-indígena consiste da proposição de um continuum do português brasileiro sob o viés afro-indígena. $\mathrm{O}$ diagrama mostra uma composição "compartilhada" com as variedades do português afro-brasileiro e português indígena.

Figura 2 - Continuum dialetal do português falado no Brasil

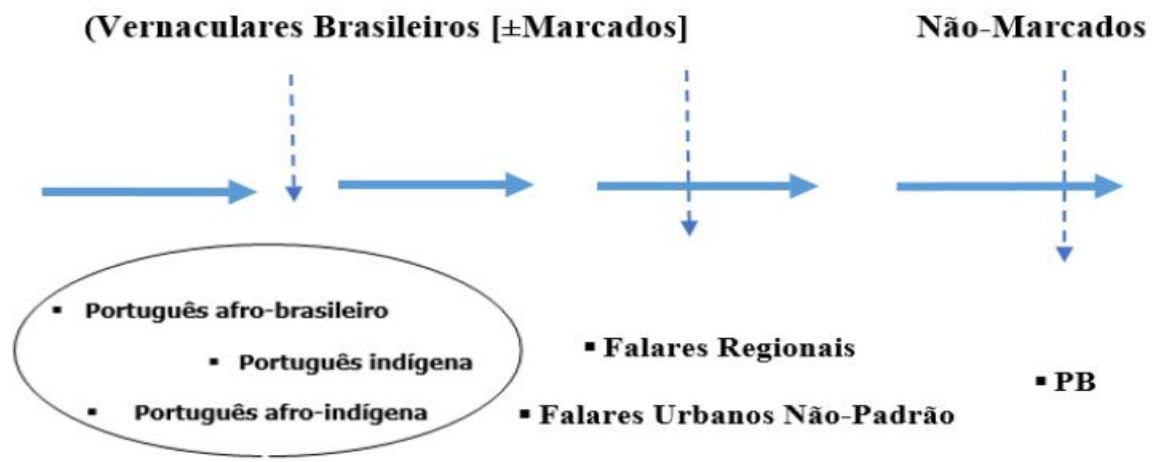

Fonte: Campos, 2014:58

Como propõe Campos (2014), as variedades [+marcadas] têm características etnolinguísticas distintas dos falares regionais e dos falares urbanos não-padrão, estes posicionados no centro do continuиm e definidos como [+/-marcados]. Enquanto falares do português brasileiro [não-marcado] estão situados na extremidade direita do diagrama, distinguindo das variedades do vernáculo regional propondo o continuum do português brasileiro.

Chamamos atenção para as variedades [+ marcadas] das quais compartilham o mesmo locus de variedades do português afro-indígena, português afro-brasileiro e português indígena. Isso significa que essas três variedades representam especificidades etnolinguísticas distintas dos falares urbanos [não-marcados] e, também dos falares regionais [+/- marcados], possivelmente, em função de haver especificidades linguísticas que reportam traços de substrato de línguas em contato.

Lançadas as primeiras indagações, a revisão do Português Afro-Indígena toma os seguintes termos: 


\section{(1) Português Afro-Indígena}

Uma variedade vernacular do português brasileiro falada por comunidades de fala 'aquilombadas'. Destacamos que tais comunidades não são apenas as "terras de preto", mas ainda as "terras indígenas" e as "terras mistas" como se dão no norte do Brasil. Nestas sociedades, verificam-se, como traços marcantes: (i) nas "terras de preto": uma descendência de africanos; (ii) nas "terras indígenas": etnias que perderam ou estão por perder por completo suas línguas maternas, mas mantém seus laços identitários; (iii) nas "terras mistas": comunidades aquilombadas no norte do Brasil cuja formação étnica é negra e indígena. Nestes três tipos de "terras" o português é traço de identidade e nossa hipótese é que cada comunidade de fala traga suas marcas específicas devendo cada uma delas, na medida do possível, ser inventariada. (Oliveira et alii, 2015:4)

O Português Afro-Indígena dialoga com abordagens linguísticas como o português étnico indígena e o português afro-brasileiro. O que temos observado (cap. 3) é que, por situarem muitas vezes no mesmo contexto

Lucchesi (2009:28-33) chama a atenção sobre a relevância dos estudos em pesquisas no interior do país, afirmando que:

[...] não se pode pensar seriamente que a língua portuguesa não foi diretamente afetada pelo contato do português com as línguas africanas de uma forma ampla e representativa, até porque os afrodescendentes se integraram em todos os segmentos sociais e nos mais diferentes ramos da atividade econômica, em todas as regiões do país; concentrando-se, porém, na base da pirâmide social, em função das adversidades históricas que tiveram de enfrentar. [...] as comunidades rurais afro-brasileiras isoladas constituem um espaço único parra a pesquisa em linguística sócio-histórica que visa rastrear os reflexos do contato entre línguas na estrutura gramatical das variedades atuais do português brasileiro.

Apesar de se tratar de uma visão afro-brasileira, é legitima o valor de estudos linguísticos voltados às variedades do português brasileiro, sejam eles resultantes do 
contato indígena, africano ou, de ambos como se reconhece em muitas comunidades quilombolas de Marajó.

No próximo capítulo trataremos dos aspectos linguísticos que sinalizam para relações de contato ocorrido no passado entre línguas africanas, indígenas e o português europeu. As variações linguísticas verificadas em Siricari, em alguns pontos, mostramse similares às variações observadas em outras comunidades quilombolas como Helvécia (in Lucchesi et alii, 2009) e, em aldeias indígena como nos povos Ãpyãwa Tapirapé (in Praça \& Torido, 2015). Apesar de haver variações comuns entre comunidades de descendência africana ou indígena, neste estudo descrevemos também algumas particularidades da linguagem de Siricari (3.4.1) que compreendem aspectos de modalidade ainda não tratados na literatura, até onde sabemos. 


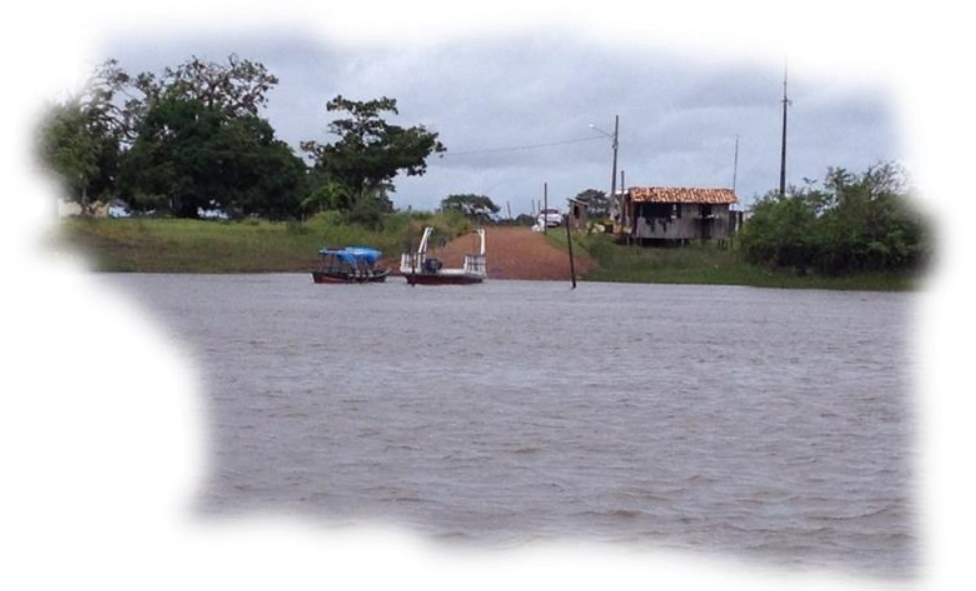

Figura 4 - Travessia de acesso para comunidades remanescentes quilombolas

Dos gêneros

Nã̃ tem esta lingua Generos; explicã̃-se porém pelos sexos femenino, ou masculino. v.g. Yalla, macho. Ngana yaalla, senhor. Muhetu, femea. Ngana ya muhetu, senhora, \&c.

Pedro Dias ${ }^{43}$, apud Bonvini, 2008:38

43 Sacerdote jesuíta, escreveu Arte da língua de Angola , redigido no Brasil em 1697. A referência acima trata-se da língua quimbundo. Conforme Bonvini (2008) a obra de Dias é uma prova histórica do emprego de uma língua africana no Brasil no século XVII. 
CAPÍtulo 3: MORfOSSINTAXe do PORTUgUÊS FAlAdo EM SiRICARI: DESCRIÇÃo E ANÁLISE

Neste capítulo listamos na seção 3.1. fenômenos relacionados à morfossintaxe do português falado em Siricari destacando, em alguns deles, estudos relativos ao português afro-brasileiro (Lucchesi, 2009), ao português étnico indígena (Ferreira, 2005; Mattos e Silva, 1988; Praça \& Torido, 2015), bem como ao português afroindígena (Campos, 2014). Na seção 3.2. sintetizamos as similaridades entre o português de Siricari e outras comunidades com intuito de dar uma visão geral sobre os dez aspectos tratados no item anterior. Em seguida, em 3.3, descrevemos aspectos relacionados à alternância vocálica $<\mathrm{u}: \mathrm{o}>\mathrm{e}<\mathrm{i}: \mathrm{e}\rangle$ atrelado à morfologia das formas verbais fui:foi e fiz:fez e, por fim, na seção 3.4, demonstramos a presença de verbo ser em final de frase, sugerindo um possível caso de modalidade.

As implicações gramaticais elencadas a seguir foram observadas em situações espontâneas e empregadas por mais de um informante. Verificamos que alguns dos eventos ocorre igualmente em estudos relacionados ao português afro-brasileiro, ao português étnico indígena e ao português afro-indígena como demonstrado no item $3.1 \mathrm{a}$ seguir. Desta forma, fizemos alguns recortes destes estudos em um breve cotejo com os falares de Siricari, sugerindo sua posição dentro do continuum dialetal do português vernacular brasileiro.

\subsection{Aspectos morfossintáticos do português falado em Siricari}

A amostra a seguir envolve dez aspectos morfossintáticos que ilustram evidências empíricas de variedades [+ marcadas] obtidas em estudo de campo na comunidade Siricari. Em cada um dos dez itens gramaticais tratados procuramos distinguir como possíveis variações relativas ao Português Afro-Indígena ( $c f$.seção 2.3). No entanto, o que segue neste capítulo representa um pequeno esboço do que pode vir a ser discutido futuramente a partir de um corpus quantitativo.

\subsubsection{Ausência de concordância de gênero}

No bojo do sintagma nominal, a ausência de concordância de gênero em Siricari tem mostrado alguma semelhança com o português popular. Vemos que a quebra da 
concordância tem ocorrido, em alguns casos, quando o nome não remete a alguma marcação imanente ao gênero ilustrado em (1), em oração relativa, cuja anáfora do sujeito da principal deveria concordar com o predicativo do sujeito (exemplo 2) e, também quando a disposição sintagmática distancia nome e complemento, como no exemplo 3.

(1) Quando viu, um sucuri já vinha na perna da minha filha. (SR-05)

(2) Ela diz que tá disposto, né. (SR-05)

(3) Quando vai sê(r) descoberto praticamente a idade e pela avaliação dele. (SR-05)

Para Castilho (2012:206) "a teoria da variação linguística tem tido uma grande repercussão na análise gramatical” e admite que "os falantes de uma língua operam com um conjunto de gramáticas de acordo com a situação linguística particular em que estão envolvidos". Para defender seu ponto de vista, o autor demonstra a falta de concordância relacionada ao gênero, como em o meu sobrinha e, para além disso, de número entre o verbo e o sujeito posposto, como em tava lá as empregadas.

Todavia outras variações de concordância de gênero conferidas em Siricari apontam para características distintas destas apontadas acima. Parece-nos que a concordância do determinante com o núcleo do sintagma nominal é aleatória. Um nome de gênero feminino apresenta um determinante de gênero masculino, ou o contrário, um nome de gênero masculino, vem acompanhado de artigo feminino. Para mais, observamos também que, em relação ao controle de anáfora, os pronomes ele $(s)$ e ela(s) parecem se neutralizarem diante de seus referentes. Um núcleo de sintagma nominal de gênero feminino não necessariamente precisa ser retomado na sentença pela proforma ela e, também, o mesmo ocorre quando o nome é masculino.

Os exemplos mostrados em (4) e (5) sugerem, em um primeiro momento, a presença de dêiticos femininos acenando para nomes masculinos antecedidos de artigo masculino (-o).

(4) Não, o tucupi ela é um líquido, é um líquido. (SR-03)

(5) Olha, essa daqui é o anajá. Cê nunca viu anajá? (SR-03)

Apesar de gramaticalmente constituir uma ausência na concordância de gênero, nos parece se tratar da omissão do termo fruta. Este termo poderia estar sendo 
considerada mentalmente pelo falante, embora não proferido na sentença, podendo ser compreendido do seguinte modo: Esssa (fruta) daqui é o Anajá. Todavia, outro tipo de construção foi observada em Siricari: referente feminino representado por dêitico masculino, como em (6), demonstrando uma marcação dêitica aleatória.

(6) Esse partizinha era uma [ININT] de plantação que num tem, que morreu tudo, era da mãe dele, né, ele comprô uma plantaçon dum pequeno que morava aqui.(SR-07)

Acerca da concordância de gênero, convém assinalar duas importantes contribuições: i) estudos afro-brasileiro, em cujas investigações demonstram que "tanto em Angola quanto em Moçambique, a variação na atribuição de gênero aos substantivos é bastante elevada, [...] imprevisível e arbitrária”, segundo Petter (in Galves, 2009:170). E (ii) estudos do português étnico indígena, nos quais mostram que para a ausência de concordância de gênero comumente empregada por exemplo no português étnico Ãpyãwa, demonstrado por Praça em comunicação pessoal, a atribuição de gênero é igualmente arbitrária.

(1) A transporte foi o seguinte: transporte, o Cimi, o Cimi Nacional, né!

(2) Duas tropólogo quer ficá sua casa. (dois antropólogos)

(3) Esse atividade está apresentando funcionamento de par mínimas.

(4) O fotografia tá demonstrando o resultado do projeto extraescolar.

(5) Disse que o pai dele era rapaz, rapazinha, e tava correndo no meio das briga.

(6) Aí ele disse que é... tinha um Tapirapé, né, que ele mexia muito no medicina natural.

Considerando que a ausência de concordância de gênero está presente em línguas africanas atuais, bem como no português indígena, podemos crer que este mesmo tipo de variação de gênero presente no português de Siricari sinaliza para um possível vestígio de falares típicos de língua africana e indígena preservado na fala dessa comunidade. 


\subsubsection{Ausência de determinante}

Em geral, o determinante é considerado um marcador pré-nominal associado ao substantivo, mantendo duas subclasses: a dos artigos definidos e a dos indefinidos. Do ponto de vista normativo, o artigo definido identifica o objeto designado pelo nome a que se liga e pode ser dispensado, caso o valor já venha expresso por outro identificador como em presença de um possessivo (meu livro). Entretanto, atualmente, a manutenção do artigo diante do possessivo (o meu livro) tem se tornado comum, conforme dispõe a gramática normativa ( $c f$. Bechara, 2010:120). Tem sido considerado, também, como arbitrariedade a presença do artigo diante de nomes próprios como em p.ex. João viajou, em cuja regra dispensa o uso de artigo junto a nomes próprios de pessoas.

Apesar da arbitrariedade normativa, o que vemos é uma frequência na marcação de artigo (e outros determinantes) em contrapartida à omissão da marca de plural nominativa no português brasileiro, como em “os menino”. Partindo dessa composição sintagmática, podemos afirmar uma tendência maior ao uso de determinantes em variações do PB do que supressão. No entanto, não é o que constatamos em Siricari, no qual observamos a ausência de determinante tanto de artigos definidos quanto indefinidos. As ocorrências demonstram que independe se a função do determinante é referencial ou se particulariza um nome. Os dados têm nos mostrado uma flutuação no uso, bem como omissão, como nos exemplos (7) a (9).

(7) Maria, num te assusta, $\emptyset$ cobra me mordeu.(SR-02)

(8) Quando nós viemo lá por debaixo da mangueira (Ø) cavalo pisava por cima que furô um buraco assim no meio, mas num era grande o buraco. (SR-02)

(9) Olhe, mamãe, (Ø) senhora faz assim, a senhora marca uma renião quando ela chegá $(\varnothing)$ senhora chame ela e diga que é tar dia a reunion aqui. (SR08)

Conforme demonstrado acima, vimos em grande parte dos dados a supressão do determinante relacionados a seres animados (cobra, cavalo, senhora). Parece-nos que o uso de artigo definido pode estar relacionado à marcação anterior de um artigo indefinido como em (8) ... que furô um buraco... era grande o buraco, e em (9) ... a senhora marca uma renião...e diga que é tar dia a reunion aqui. 
Na visão gramatical do português normativo Cunha \& Cintra (apud Castilho, 2012:492), a ausência do artigo "acarreta a perda da particularização de referencialidade". De acordo com os registros (7) e (8) o que vemos é a omissão de artigos indefinidos uma/um, apontando para uma situação indefinição dos termos cobra e cavalo. Ou seja, qualquer cobra e qualquer cavalo. Não há na fala dos informantes a necessidade de se definir, ou particularizar que cobra ou cavalo o falante se refere. Com isso, entendemos que sob o ponto de vista do informante, há um domínio radicado na pragmática da língua, da qual considera o emprego do artigo indefinido excedente ou uma redundância na marcação, uma vez que para o falante desta comunidade compreende-se a indefinição a partir da omissão gramatical.

Já no exemplo (9) o que obtivemos foi uma flutuação na marcação do artigo, em que se observa ora o uso diante do pronome de tratamento senhora, ora supressão da marca gramatical. Sob esse aspecto vale a pena tecer um pequeno comentário obtido em comunicação pessoal com Praça ${ }^{44}$ em que diz ser a ausência de artigo frequente no português étnico indígena. No português dos povos Ãpyãwa ${ }^{45}$, embora se trate de uma situação de bilinguismo em Ãpyãwa como $L_{1}$, e português como $L_{2}$ existe o seguinte arranjo: Banana cria bem $\emptyset$ criançada ${ }^{46}$.

Vale apontar que a ausência de artigo não estava presente na gramática latina, bem como na língua brasílica e, evidentemente, na LGA ( $c f$. Simpson, 1955; Poggio, 2002). Deste modo, entendemos que a omissão deste determinante pode representar um resquício de falares indígenas, sobretudo da LGA, dada a sua permanência e abrangência na região norte brasileira.

44 Profa. Dra. Walkíria Neiva Praça é professora adjunta do Departamento de Linguística, Português e Línguas Clássicas (LIP) da Universidade de Brasília e tem estudado a língua Ãpyãwa (Tupi-Guarani) desde 1997. Recentemente também se dedica aos estudos comparativos entre o Ãpyãwa, o Nheengatu e Tupinambá, bem como a descrição do Português Ãpyãwa.

45 O povo Ãpyãwa é tradicionalmente conhecido como Tapirapé e vive em duas áreas indígenas: a Terra Indígena Tapirapé/Karajá e a Terra Indígena Urubu Branco (Tãpi'itãwa). A primeira localiza-se às margens do rio Tapirapé, nos municípios de Luciara e Santa Terezinha no Mato Grosso. A segunda localiza-se nos municípios de Santa Terrezinha, Confresa e Porto Alegre do Norte, situada no nordeste do Mato Grosso e tem como centro a serra do Urubu Branco. Essa se distancia da Terra Indígena Tapirapé/Karajá cerca de $180 \mathrm{~km}$. Ambas as Terras Tapirapé (Ãpyãwa) - doravante apenas Ãpyãwa fazem divisa com grandes latifúndios, dos quais visam apenas à exploração do solo, aspecto muitas vezes conflitante com a cultura indígena. (cf. Praça, 2007:21-22)

${ }^{46}$ Exemplos referentes ao português étnico Ãpyãwa (Tapirapé) foram obtidos por meio de comunicação pessoal com a Profa. Dra. Walkíria Neiva Praça. 


\subsubsection{Ausência de preposição}

Mattoso Câmara (1976:177) aponta que é um traço “característico das línguas românicas o desenvolvimento de um sistema de preposições para estabelecer relações de subordinação entre os constituintes de uma oração". Conforme o mesmo autor, o sistema preposicional em português funciona no plano das localizações no espaço e tempo; e no plano do modais, com conceituações de estado, origem, posse, finalidade, meio, causa, entre outros. As preposições, dadas como elementos gramaticais, podem assumir funcionalidades diversas, tal como ensina Castilho (2012:583) elas "são palavras invariáveis que atuam como núcleo do sintagma preposicional desempenhando funções sintáticas, semânticas e discursivas". Sob o ponto de vista funcionalista (Bagno, 2001:145; Mattoso Câmara, 1975:181) algumas preposições têm sofrido aparente declínio, como a preposição $a$, demonstrando acentuada preferência pela preposição em ou para. Esse comportamento pode ser descrito como em: Sentei-me à/na mesa ou Telefonei a/para Pedro.

Considerando que as preposições desempenham um papel na estrutura da língua e, portanto, inseridas em um conteúdo nocional, argumentamos em que medida supressão de uma preposição constituiria em perda de significado proposicional. Constatamos na fala da comunidade Siricari omissões de preposições com maior valor gramatical, ou consideradas "mais abstratas", como as preposições: $a$, de, em etc. e estabilidade em preposições que conservam mais sua função básica como: ante, após, desde, sem etc. Observamos que a ausência de preposição pode ocorrer entre verbos (cansei trabalha) como em (10); precedido de advérbio (lá) como em (11) e, em alguns casos, quando há a presença da preposição ela pode vir em junção da preposição $(\mathrm{em})+$ advérbio (atrás) como em (12). Destes exemplos, o tipo mais comum de construção em supressão de preposição ocorre como em (10) e (13).

(10) Eu era auxiliar administrativo, depois cansei $\emptyset$ trabalhá na parte burocrática. (SR-09)

(11) Era do meu pai lá Ø o Paixão ${ }^{47}$, enton cês se viro. (SR-08)

\footnotetext{
${ }^{47}$ Paixão é o nome dado a uma comunidade quilombola próxima à Siricari.
} 
(12) Aqui natrás desse mato aqui, a gente nunca achô assim... a gente tem muito caco de loça. (SR-10)

(13) Então é quando vai sê(r) descoberto praticamente a idade e pela avaliação dele, ele diz que ela morreu mais ou menos $\emptyset$ (com) uns cem anos, que ele falô. (SR-05)

(14) Nesse tempo você comprá uma bicicleta tinha $\emptyset$ haver vinte merréis, era muito dinhero.

Algumas dessas variações são observadas no português brasileiro popular, assim considerado por Castilho (2012:2008), o qual aponta a presença de supressão da preposição em alguns complementos oblíquos, como em Eu preciso $\emptyset$ isso. Este tipo de ocorrência está demonstrado em (10) em cujo trecho [...] cansei Ø trabalhá compartilha dessas propriedades variáveis apontadas pelo autor. Todavia em (11) a elisão da preposição de, ocorre ainda que presente o artigo o [...] Era do meu pai lá Ø o Paixão. Nesse tipo de ocorrência encontramos o uso do artigo em situação flutuante, pode ou não ocorrer.

Em relação às locuções prepositivas observamos a presença de preposição em locuções do tipo: graças a, embaixo de, em cima de. No entanto, poucas vezes notamos flutuações na aplicação preposicional em junção com advérbio, conforme se verifica em (12) natrás de, variante de por trás de ou atrás de. Também percebemos que a ausência de preposição independe de sua função (complemento) ou se concentra algum conteúdo semântico como demonstrado de (10) a (13). Em (14), chamamos atenção para a supressão da preposição na locução verbal: verbo auxiliar [- preposição] + verbo no infinitivo, resultando em uma oração do tipo: tinha $\emptyset$ haver funcionando como variante de tinha 'de' haver $\approx$ tinha 'que' haver. Nota-se que semanticamente, o verbo haver, proferido pelo informante, traz uma ideia de posse, caracterizando um atributo lexical conservador.

Diante do que foi revelado, parece-nos que a ausência de preposição não incide em ruptura semântica, mas sim, em uma particularidade linguística de comunidades envoltas em uma constituição linguística marcada por contato com outras línguas. A exemplo disso, temos os estudos de Lucchesi, Baxter e Ribeiro (2009:93) que discutem o fato de algumas variantes gramaticais trazerem vestígios característicos de línguas crioulas. No entanto, afirmar esta proposição para as variantes de Siricari demandaria 
investigações de cunho quantitativo e maior aprofundamento histórico das línguas que ali serviram de base para essa variação do português brasileiro.

\subsubsection{Ausência de concordância de número}

Estudos como o de Scherre (1988:154), Guy (1981:168) têm demonstrado que a primeira posição favorece a presença de marca de plural e que as posições para a direita são desfavoráveis à marcação. As amostras colhidas em Siricari, exemplos (15) a (17), apontam para a tendência de marcação no primeiro elemento do sintagma nominal, como frequentemente tem-se visto no português popular brasileiro.

(15) Acho que a gente vai nas casa aqui que são os moradô mais velho, né. (SR-04)

(16) Eles contava as história, né. (SR-08)

(17) Isso era fábrica de índio. Se via umas panelinha bonitinha. (SR-02)

Para Scherre (apud Castillho, 2012:492) "quando a marcação de número deixa de ser redundante, é no primeiro elemento do sintagma nominal que aparece essa marcação". Assim, os determinantes nas, os, eles, as e umas - cf. exemplos (15), (16) e (17) cumprem com exclusividade a função de marcação de número. Chamamos atenção para a situação em que a ausência de marcação em termo anterior leva a ausência de marca no termo seguinte, como em (17) Isso era fábrica de índio. Se via umas panelinha bonitinha.

Um ponto interessante acerca da marcação de número é que, apesar de se tratar de uma variável em posição inicial do SN como demonstrado nos exemplos acima, registramos uma situação de marcação de plural à direita, como ilustrado a seguir:

(18) [...] muita forte dores no meu corpo (SR-05).

Apesar de se tratar de exemplo único, incipiente em termos de característica de variação linguística em Siricari, esse tipo de marcação de plural à direita nos remete a dois importantes estudos relacionados à linha contatista, que correlacionam variáveis do PB ao contato linguístico. O primeiro refere-se a estudos de Praça (2007:61), que explica ser "a categoria de número no português do povo Âpyãwa expressa de distintas maneiras. As noções de singular e plural são marcadas nos índices de pessoas". A autora evidencia que no português dos Ãpyãwa o referente de pessoa pode configurar a 
posição nuclear do SN. Isso porque a estrutura linguística da língua Apyãwa corrobora para que ocorra a marca de plural apenas no referente nominal em português, como em: o meninos viu a vacas, caracterizando neste caso interferência de substrato Ãpyãwa, na língua adquirida - o português $\left(\mathrm{L}_{2}\right)$ ( $c f$. Praça \& Torido, 2015:13). O outro estudo que entendemos de suma importância para investigações de marcação de plural à diretira refere-se ao português étnico Huni-Kuin ${ }^{48}$. Conforme demostrado por Christino $\left(2015^{49}\right)$, as manifestações do português oral dos povos Huni-Kuin indicam clara transferência de marcação de plural à direita (nosso arrecurso naturais), aspecto este característico das línguas Pano e reportado para o português $\left(\mathrm{L}_{2}\right)$.

Já na esfera “afro-brasileira”, estudos de Guy (1989, apud Baxter,1995:78) sobre as línguas africanas que mais provavelmente teriam influenciado o português brasileiro -línguas Kwa, da África ocidental; e as línguas Banto do Congo e da Angola - têm mostrado que todas essas línguas "apresentam regras que marcam o plural numa posição no início do SN". O que podemos entender dos estudos trazidos por Guy, Praça e Christino, o exemplo (18) observado em Siricari mostra-se fraco para apontar como característica relativa a marcação de plural à direita. No entanto, verificada essa ocorrência, vale advertir para este fenômeno em futuras coletas de fala em Siricari ou comunidades afins próxima a ela, uma vez que esse tipo de evento pode implicar em mecanismos linguísticos herdados de uma situação de contato entre o português europeu com as línguas indígenas e africanas presentes no passado e mantidos na fala destas comunidades.

\subsubsection{Ausência de cópula e outras supressões verbais}

Verbos de cópula, tratados como verbos de ligação ou predicativos, podem se manifestar em sintagmas adjetivais, nominais, preposicionais e adverbais com função de predicativo. Ou seja, são os verbos de ligação ser, estar, ficar, permanecer, continuar, etc. que funcionam como cópula na maior parte das orações. Assim, em uma estrutura

\footnotetext{
${ }^{48}$ O povo Kaxinawá ou Huni Kuin (gente verdadeira) como eles se denominam, vive em terras situadas no Brasil e no Peru. No Brasil, o território do povo Kaxinawá localiza-se no Estado do Acre, nas regiões dos Vales do Purus e Juruá, enquanto que no Peru seu território está localizado a partir do rio Curanja.

${ }^{49}$ Anotações da comunicação oral apresentada pela Profa. Dra. Beatriz Protti Christino "O papel da saliência fônica na marcação de plural em Português Huni-Kuin". IX Congresso Internacional da ABRALIN em fevereiro de 2015.
} 
como Ele ficou aborrecido, podemos confirmar a relação do predicativo (aborrecido) com o sujeito (ele), em cópula com a forma verbal ficou.

Nesta seção demonstramos registros obtidos na fala de Siricari, indicando ausência do verbo de cópula ilustrado em (21), (19) e (20), nos parecendo possível explicar a partir da predicação promovida pelos adjetivos alocados na frase.

(19) Minha mãe faleceu dia dez de junho, mas ela Ø muito, muito já idosa, muito mesmo. (SR-05)

(Minha mãe faleceu dia dez de junho, mas ela era muito, muito já idosa, muito mesmo)

(20) Ela disse "o senhor não é Deus, o senhor Ø médico da terra”. (SR-08)

(Ela disse "o senhor não é Deus, o senhor é médico da terra”) entendimento com ela, né)

(21) Aí eu foi com a Dra. Maria de Lurdes, que nesse tempo ela até dava serviço aí, Ø juíza em Salvaterra. Aí eu fui falá cum ela, tomá um entendimento com ela, né. (SR-02)

(Aí eu fui com a Dra. Maria de Lurdes, que nesse tempo ela até dava serviço aí, era juíza em Salvaterra. Aí eu fui falar com ela, tomar um entendimento com ela, né.)

Apesar da supressão da cópula, vimos que é possível o entendimento da proposição, ou seja, dos dados obtidos em Siricari, a ausência do elemento cópula não afeta em nada o significado da sentença. Estudos de Hengeveld (1992:32) mostram que a cópula constitui em parte a categoria de verbos auxiliares os quais são semanticamente vazios. De maneira ampla, a cópula pode ser definida como uma categoria de suporte que, em algumas circunstâncias, ela pode deixar de ser empregada sem afetar o significado da sentença, como propõe o autor:

A característica mais marcante da cópula é que ela não faz contribuições independentes ao significado da sentença. Essa característica é refletida no fato de que algumas linguagens e em circunstâncias variadas, a cópula pode ser desconsiderada sem afetar o significado da sentença. Da sua função de suporte, segue que a copula 
em si, não é uma parte do predicado, mas um auxiliar acompanhando um predicado não verbal e seus argumentos. (tradução livre - texto original em nota de rodapé s0 $^{50}$

Curiosamente, um pouco além da configuração copulativa, outro tipo envolvendo omissão verbal nos chamou atenção. Os registros mostraram ausência verbal incidindo sobre verbos dicendi, como em (22), verbos plenos precedidos de auxiliares como em (23) e parte do exemplo (21) aqui renumerado em (24), bem como sobre verbos declarativos, ilustrado em (25).

(22) Ela (Ø) "tia eu vô fazê pra senhora vê" eu digo "minha filha num fica doce não". (SR-03)

(Ela disse: "tia, eu vou fazer para a senhora ver". Eu digo: "minha filha, não fica doce não")

(23) Aí me mandaro ir $\emptyset$ com prefeito. (SR-05)

(Aí me mandaram ir falar com o prefeito)

(24) Ai eu foi $\emptyset$ com a Dra. Maria de Lurdes que nesse tempo ela até dava serviço aí [...] (SR-02)

(Aí eu fui falar com a Dra. Maria de Lurdes, que nesse tempo ela até dava serviço aî)

(25) Olha, eu vou lhe dar um parecer, já tem gente no Ajuda ${ }^{51} \emptyset$ que quando ela chegá vão metê na cabeça dela pra ela lhe tomá esse forno.(SR-02)

(Olha, eu vou lhe dar um parecer, já tem gente no Ajuda dizendo que quando ela chegar vão meter na cabeça dela para ela lhe tomar esse forno)

O tipo de construção ilustrado em (22) a (25) está presente na fala de diferentes informantes e são, de certo modo, comuns às narrativas. Isso nos leva a acreditar haver

50 The most salient feature of the copula is that is makes no independent contribution to the meaning of the sentence. This feature is reflect in the fact that in some languages and under varying circumstances the copula can be left out without affecting the meaning of the sentence. [...] From its supportive function it follows that the copula itself is not a (part of the) predicate, but an auxiliary accompanying a non-verbal predicate and its argument(s).

51 “Ajuda": nome de uma comunidade remanescente quilombola próxima à Siricari. 
uma inferência sugerida no entendimento proposicional. Assim, entendemos tratar-se de um modo de falar particular no qual o falante confia que as omissões verbais serão preenchidas pelo ouvinte a partir da exposição da narrativa.

Apesar da importante demonstração desse tipo de construção sintática, as evidências que trazemos necessitam de maiores critérios para caracterização desse fenômeno. Reconhecemos, portanto, a relevância de futuras investigações para elucidar de modo mais criterioso e quantitativo esta matéria.

\subsubsection{Orações encaixadas sem complementizador}

Complementizadores são elementos de natureza conjuncional que introduz uma oração encaixada ou tratada também como subordinada. Para Payne (2006:123) complementizadores são palavras que introduzem uma cláusula completa quando esta é parte de outra cláusula ou frase [...] na língua inglesa é o termo that que ocorre na sentença. ( $c f$ texto original em nota de rodapés2)

Tipo de construções sem complementizador foram verificadas em Siricari e resultam, na maioria das vezes, em supressão da conjunção que, bem como quando este termo funciona como pronome relativo, conforme destacado a seguir:

(26) A que mais coisa é essa que mora aí no Boa Vista, mas $\emptyset$ vocês entrare na casa dela pensa até que é casa de quem é rico. (SR-08)

(A que mais coisa é essa que mora aí no Boa Vista, mas se vocês entrarem na casa dela pensam até que é casa de quem é rico)

(27) E arruma um companheiro $\emptyset$ eu venho. (SR-02)

(E arruma um companheiro que eu venho)

(28) Por aqui era só ele e um senhor lá no Boa Vista ${ }^{53} \emptyset$ serrava madera pra todo esse pessoal aí. (SR-05)

(Por aqui era só ele e um senhor lá no Boa Vista que serrava madeira para

\footnotetext{
52 "complementizers are words that introduce a whole clause when it is a part of another clause or phrase $[\ldots]$ in English is the unstressed that that occurs in a sentence"

${ }^{53}$ Boa Vista: comunidade remanescente de quilombo próxima de Siricari.
} 
todo esse pessoal aí)

Mas é pra tal mês $\emptyset$ essa criança vai nascê. (SR-10)

(Mas é para tal mês que essa criança vai nascer)

(30) Aí ele disse $\emptyset$ ele vai botá na internet e vai procurá. (SR-08)

(Aí ele disse que ele vai botar na internet e vai procurar)

A descrição desses dados nos leva a aspectos relacionados tanto à perspectiva diacrônica, como revela estudos do Português Afro-Indígena ( $c f$. página 53 deste estudo), bem como estudos relativos ao contato linguístico. Cremos que, se por um lado o português quinhentista revela a ocorrência de ausência de complementizador em períodos do tipo: a conta [...] depois $\emptyset$ promette ha-de tomar a todo genero humano (Vieira, 1689:1), por outro acreditamos ser arriscado crer que a variação observada em Siricari retrate um fenômeno natural ${ }^{54}$ da língua. Isso porque estudos relacionados a variantes do PB decorrente de contato linguístico nos mostram que a construção de orações encaixadas sem complementizador está presente tanto no português étnico indígena, quanto na fala de remanescentes quilombolas, incluindo a comunidade de Helvécia ${ }^{55}$, cujos estudos apontam a existência de marcas de um português crioulo. Essa variação pode ser constatada no exemplo referente ao português étnico Ãpyãwa ${ }^{56}$ : (a) Eu vai $\emptyset$ você volta (eu vou se você voltar), bem como de registros colhidos em Helvécia (cf. Lucchesi, 2009: 91) ilustrado em (b) Ele disse Ø a irmã dele veio do Rio.

O que entendemos dos dados obtidos em Siricari são variações linguísticas cujas características e contrapontos demonstram integrar um grupo particular de falares que vai ao encontro do continuum proposto pelo Português Afro-indígena (seção (2.3)).

\footnotetext{
54 Basicamente há duas correntes de pensamento que tratam o estudo das variantes linguísticas: a perspectiva que discute os fenômenos com base na antiga deriva secular das línguas indo-europeias em geral e das línguas românicas e, tratado como processos 'naturais da língua', nos termos de Sapir (1949/1921), seguindo esse ponto de vista estudos de Naro (1981), Tarallo (1993), Scherre (2007). E a outra é a perspectiva contatista, que trata os fenômenos das variantes com base no contato linguístico, como em Lucchesi, Baxter \& Ribeiro (2009), Guy (1989).

55 Conforme se depreende em Lucchesi (2009:91) há evidências empíricas que sustentam a possibilidade de ter ocorrido, em Helvécia, uma situação de crioulização em sua formação histórica.

${ }^{56}$ Dado obtido em comunicação pessoal com a Profa. Dra. Walkíria Neiva Praça.
} 


\subsubsection{Variação de regência}

Alguns casos particulares de regência podem ser interessantes tratar aqui, haja vista a flexibilidade no uso de diferentes preposições, como ocorre com o verbo ir. Apesar de condenado pela gramática normativa, esse verbo pode reger, além das preposições convencionadas $a$ e para, a preposição em. Assim contidas em orações do tipo: Hoje vou a sua casa/Hoje vou para sua casal Hoje vou na sua casa. Essa flexibilidade, no entanto, não é possível incidir sobre qualquer verbo, tampouco para qualquer preposição.

Dados constando transferência de regência em Siricari, a princípio, foram poucos, mas não insuficientes para desprezá-los, uma vez que estudos têm dado indícios de mesmo tipo de evento no português étnico indígena. É possível que novas amostras em Siricari seja possível obter dados quantitativos desse tipo de evento linguístico. O que nos chama a atenção neste aspecto é que a ausência de elementos conectores como preposições (3.1.3) e conjunções (3.1.6) pode ser um indicativo para baixa ocorrência de transferência de regência no português de Siricari.

Vejamos alguns exemplos que ilustram esse tipo de ocorrência:

(31) E tô contando da história. (SR-08)

(E estou contado a história).

(32) Eu tava com cinco mês ela disse que eu enjoei o peito, num quis sabê. (SR-08)

(Eu estava com cinco meses. Ela disse que eu enjoei do peito, não quis saber).

Em comunicação pessoal, Praça atesta que no português étnico Ãpyãwa a transferência de regência é bastante comum e ocorre tanto na fala quanto na escrita conforme demonstrado nos exemplos: (i) "A gente ia, mas o presidente nunca creditava a gente" (fala) e, (ii) "contamos a presença de todos (as) acadêmicos (as) da licenciatura Intercultural" (escrita). 


\subsubsection{Inversão da ordem sintática}

A ordem não marcada no português brasileiro é SVO, como em $O$ menino leu o livro. Conforme Castilho (2012:270) a movimentação dos constituintes SVO em algumas construções tidas como marcadas, apesar de observável no PB, causam certo estranhamento, como em estruturas do tipo: O livro o menino leu (OSV); O menino, o livro leu (SOV); Leu o menino o livro (VSO). Para esse autor, o português brasileiro marcha para uma língua de ordem rígida SVO.

Dos deslocamentos no PB aquele que tem se mostrado mais frequente são construções à esquerda do tipo OSV, como $\boldsymbol{O}$ bolo a Maria comeu; Ninguém me recomendou estes $C D s$; promovendo movimentação do objeto para a topicalização. ( $c f$. Castilho, 2002). Na investigação realizada em Siricari, verificamos que, apesar de a sintaxe SVO ser recorrente, constatamos construções do tipo VS, conforme ilustrado em (33).

$$
\text { Ele veio prestá socorro, que ficô ali em Boa Vista o carro. (SR-05) }
$$

Apesar de esse tipo de movimentação de ordem sintática não ter se mostrado frequente nos registros do português falado em Siricari, é instigante indagar sobre quais fatores teriam contribuído para esse tipo de organização frasal.

Para Eunice Pontes (1987:163 apud Berlinck, in Tarallo, 1989:95)

Parece claro que a língua portuguesa hoje é predominantemente SV. A ordem VS se mantém em casos especiais, sobretudo em orações marcadas em relação à oração declarativa, afirmativa, neutra.

Do ponto de vista de Pontes, a ordem VS se restringe a "casos especiais" (expressão cunhada pelo autor), ou seja, se reduz a construções marcadas e infrequentes. Sobre isso, vale apontar o trabalho de Chaves (1989:69) no qual a autora demonstra a alta frequência da ordem VS em região de fronteira, como destacado na oração: $A$ semana passada esteve aqui uma amiga minha, é carioca ela.

Entendemos que este tipo de ocorrência, bastante comum na região urbana do Pará, embora não tenhamos registrado esse fenômeno na fala da comunidade Siricari consideramos relevante a observação deste evento em novas investigações. 


\subsubsection{Ausência de concordância verbal}

A ausência de concordância verbal tem sido explicada por Castilho (2012:411) como uma "conformidade morfológica entre uma classe (neste caso, o verbo) e seu escopo (neste caso, o sujeito) que implica [...] na redundância de formas, ou seja, se houver marcação de plural no sujeito haverá marcação de plural no verbo". Essa redundância de formas apontada por Castilho procura justificar algumas construções consideradas em desacordo com os padrões gramaticais do português apontando que pode se tratar de:

(i) Proximidade ou distanciamento entre verbo e sujeito (As contas deste ano, sobretudo depois que eu tive um pequeno aumento salarial, pesou na minha decisão de fazer mais economia);

(ii) Posição do sujeito na sentença (Chegou, depois de muita espera, as roupas que você encomendou);

(iii) Paralelismo linguístico (Tem outros que fala demais e num diz nada que se aproveite);

(iv) Saliência fônica (Eles fala que eles faz o que eles quer).

Além disso, não apenas estes elementos podem incidir sobre a perda da concordância verbal, como também a disposição em que se encontra o quadro pronominal brasileiro. De acordo com Mattos e Silva (2004:144) o paradigma verbal tem se regularizado ocorrendo a expansão da forma verbal de terceira pessoa do singular sobre as demais posições pronominais.

A seguir, reproduzimos o quadro pronominal proposto pela mesma autora acima a qual realça as posições de um parâmetro verbal alterado mediante a modificação do quadro pronominal de pessoa.

\begin{tabular}{|c|c|c|c|}
\hline $\begin{array}{l}\text { 1. Exp } \\
\text { você }\end{array}$ & $\begin{array}{l}\text { 2. Redu } \\
\text { tu, vc }\end{array}$ & $\begin{array}{l}\text { 3. Gene } \\
\text { da } 3^{a} p\end{array}$ & $\begin{array}{l}\text { ralização } \\
\text { ssoa verbal }\end{array}$ \\
\hline $\begin{array}{c}\text { Norma Padrão } \\
\text { (6 posições) }\end{array}$ & $\begin{array}{c}\text { PB } \\
\text { (4 posições) }\end{array}$ & $\begin{array}{c}\text { Português popular } \\
\text { (3 posições) }\end{array}$ & $\begin{array}{l}\text { Português popular } \\
\text { (2 posições) }\end{array}$ \\
\hline eu falo & eu falo & eu falo & eu falo \\
\hline \multicolumn{4}{|l|}{ tu falas } \\
\hline ele fala & você, tu, ele, a gente fala & você, tu, ele, a gente fala & $\begin{array}{l}\text { você, ele, a gente, eles, } \\
\text { vocês fala }\end{array}$ \\
\hline nós falamos & nós falamos & & \\
\hline \multicolumn{4}{|l|}{ vós falais } \\
\hline eles falam & vocês, eles falam & vocês, eles falam & \\
\hline
\end{tabular}


Ressalvamos, também, que a autora distingue a ocorrência de paradigma verbal até duas posições a falantes menos escolarizados ou não-escolarizado, e ou sobretudo, procedentes de áreas rurais. Entretanto, construções demonstrando a ausência de concordância entre sujeito e verbo podem ocorrer também em grandes centros urbanos independente do nível de escolaridade. Em estudos sobre aspectos da concordância de número no português do Brasil Scherre (1994:11) conclui que:
A variação na concordância de número no português falado no Brasil está definitivamente internalizada na mente de seus falantes. Trata-se de uma variação inerente, altamente estruturada em função de aspectos linguísticos e sociais.

Deste modo, não há que se rotular construções do tipo (34), verificadas em Siricari, como situações de fala relativa apenas à área rural.

(34) Ele vem, faz a nossa comida, nós come. (SR-07)

A bem da verdade, apesar de a mudança do quadro pronominal promover alterações de concordância entre sujeito e verbo, há variações que ainda estão por ser respondidas. Os exemplos (35) a (38) vêm ilustrar variações entre o pronome de primeira pessoa e verbo em terceira pessoa do singular ocorridas com verbos de vogal interna variando entre $i / e$ bem como $o / u$. Vejamos:

(35) Eu teve onze filhos. (SR-08)

(36) Eu fez parto de criança que nasceu de bunda. (SR-05)

(37) Eu foi pra Belém de avion. (SR-08)

(38) Quando eu teve trabalhando lá na delegacia. (SR-02)

Entre alguns trabalhos realizados com a propositura da mudança do quadro pronominal Castilho (2012) e Mattos e Silva (2004) alegam haver uma regularização total do paradigma verbal de terceira pessoa do singular. No entanto, essa teoria não esclarece a variação observada em Siricari contida nos exemplos (35) a (38), principalmente em se tratando de alternância entre vogais $i / e$ bem como $o / u$. Também essa teoria não esclarece a ausência de concordância entre sujeito e verbo em construções com pronome em terceira pessoa e verbo em primeira pessoa, constante em Siricari conforme destacamos abaixo: 
Sobre esse fenômeno consideramos oportuno dedicarmos a seção 3.3 especialmente para tratar desse evento gramatical, uma vez que as características indicam aspecto peculiar na fala de Siricari, embora não exclusivo dessa comunidade.

Ressaltamos que os fenômenos gramaticais tratados neste tópico (3.1.9) não fazem parte de falares apenas em Siricari. Registros semelhantes são também apresentados em estudos de comunidades aquilombadas e aldeamentos indígenas como Helvécia ${ }^{57}$, Parkatêjê $\hat{e}^{58}$ e Kamayurá ${ }^{59}$ de modo que essa variedade, conforme assinala Baxter (1997:269), se difere de áreas rurais em geral. Ou seja, podemos considerar que este evento pode ser observado com a lente do contato linguístico e não como característico da assimetria entre os elementos da frase.

Evidências gramaticais como a tratada neste tópico sugerem transferências estruturais da língua primeira. Lucchesi, Baxter e Ribeiro (2009:16) apontam indivíduos que exibem uma variação oral da forma padrão do português em alternância com formas que teriam feito parte do repertório gramatical do antigo crioulo em Helvécia, por exemplo "Eu trabalha no roça; Quando eu veio logo, ele já toma; Eu comê só uma $v e z^{60}$ ". Segundo esses autores, a ausência de concordância de $1^{\mathrm{a}}$ pessoa do singular pode ser um indicativo de uma variação decorrente do contato entre línguas (2009:93).

No mesmo sentido, no português étnico Parkatêjê ocorre o mesmo aspecto linguístico. Ferreira (2005:13) demonstra que em uso da língua portuguesa como $\mathrm{L}_{2}$, os falantes tendem ao emprego da forma verbal de terceira pessoa diante de primeira pessoa pronominal tal como: "eu fez, eu foi, eu pediu".

Em Mattos e Silva (1988:86) consta que o português de transição dos índios Kamayurá assinala uma "flutuação" na morfologia verbal de primeira pessoa do singular do seguinte modo:

a) Eu fuma..., pois não.

57 Helvécia: comunidade quilombola localizada nas margens do Rio Peruípe, doze léguas acima de Nova Viçosa, na comarca de Caravelas, no extremo sul da Província da Bahia.

58 Parkatêjê: aldeia indígena próxima ao município de Bom Jesus do Tocantins, 30 km de Marabá, Sudoeste do Pará.

59 Kamayurá: aldeia indígena localizada cerca de dez quilômetros a norte do Posto Leonardo VillasBôas, a aproximadamente 500 metros da margem sul da Lagoa Ipavu e seis quilômetros do rio Kuluene, Mato Grosso.

${ }^{60}$ Dados extraído do site Vertentes: http://www.vertentes.ufba.br/a-comunidade-de-fala-de-helvecia-ba 


\section{b) "Você come aquilo?" \\ - "Não, não come, não.}

Segundo a mesma autora, tal fato se justifica pelo desconhecimento da norma gramatical. O emprego verbal de terceira pessoa do singular em posição de primeira pessoa pronominal denotaria um "reflexo" do verbo utilizado na situação de interlocução como se entende em (b). Apesar desta reflexão, entendemos que há uma relação pragmática de transferência estrutural de $\mathrm{L}_{1}$ para a segunda língua $\left(\mathrm{L}_{2}\right)$.

\subsubsection{0. [nวs] em situação de oblíquo}

Observamos abertura das vogais na comunidade Siricari em ocorrência como

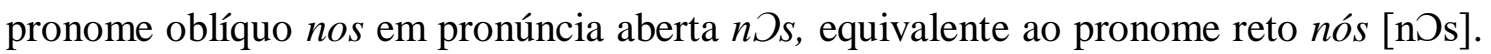
Esse mesmo evento foi notado também em breve conversa que tivemos com moradores da comunidade Salvá, próxima à Siricari, bem como em alguns falares populares da cidade de Belém. Esse tipo de ocorrência integra os exemplos a seguir:

(40) Ela agora tão $\boldsymbol{n}$ ○s dando um apoio, né. (SR-10)

(41) Aqui já tinha sido fazenda, que ele nOs contava, né. (SR-10)

Apesar de não ser objeto deste estudo os segmentos fonéticos envolvidos nas variantes desta comunidade, entendemos ser importante componente para futuras pesquisas, uma vez que contatamos outros termos cujo fonema / $\mathrm{D} /$ ocorre.

(42) Eu já num... p Pr mim já num quero mais nada. (SR-08)

(43) Ali em Monsarás tudo p Pr lá eles foro passando, em Monsarás tem até um poço no meio da rua diz que hora de meio dia a gente olha lá diz que enxerga um galo, né, diz que um galo de oro lá, mas isso sabe lá quem é que enxerga, né. (SR-08)

Temos registro desta variante [nวs] no português Afro-Indígena da comunidade de Jurussaca ${ }^{61}$, analisada por Campos (2014:172-175), do qual aponta que neste caso 
“não há a distinção fonológica entre /nós/ 'nominativo' e /nos/ 'não nominativo' como há no $\mathrm{PB}$, com a oposição em que / / e /o/ constituem pares mínimos $(/ \mathrm{O} / \neq / \mathrm{o} / \mathrm{)})$.

As ocorrências verificadas em Siricari demonstradas em nos (40) a (43) apresentam colocação pré-verbal, tal como no exemplo demonstrado por Campos (2014:173) na comunidade de Jurussaca: Eles nós duaru mil reais; Sempre, aqui eles nós chamavam assim". Para esse autor, "a assimetria do pronome de primeira pessoa nós - oferece pistas para formular a hipótese de que a neutralização entre as formas "nós" e "nos" pode ter ocorrido em algum estágio da fala de Jurussaca, acarretando a homofonia das duas formas" ( $c f$. Campos, 2014:174).

A literatura nos mostra haver estudos que tratam de investigações linguísticas de ordem fonética/fonolóligica, como investigações realizadas pela Profa. Dra. Regina Cruz $^{62}$ sobre Vogais na Amazônia Paraense (Alfa, São Paulo, 56 (3): 945-972, 2012 945), que analisam marcas sociolinguísticas de cinco variedades do português falado na Amazônia Paraense (Cametá, Mocajuba, Breves, Belém e Breu Branco). Neste sentido, entendemos que, em futuras investigações em Siricari, o Projeto Norte Vogais poderá corroborar acerca desse aspecto fonético verificado em Siricari, especificamente no que se refere à ocorrência do pronome oblíquo nos sob uma pronúncia aberta $n \supset s$, do qual pressupomos tratar-se de um evento decorrente de contato interdialetal.

\subsection{Algumas considerações}

Das estruturas linguísticas tratadas ao longo da seção 3.1 poderia haver o argumento de que poderiam ser frases resultantes da inadequação de aprendizagem de regras gramaticais, características de fala popular distante da forma padrão, ou mesmo fatos relacionados a permanência de um antigo português europeu popular. Todavia, a perspectiva tipológica nos autoriza apontar para aspectos linguísticos relacionados a influências de outras línguas. A esse respeito, reportamos ao estudo de Margarida Petter intitulado O continuum afro-brasileiro do português (in Galves, Garmes \& Ribeiro, 2009:159-173) no qual a autora chama a atenção para as semelhanças entre línguas africanas do grupo banto com variedades do português brasileiro. Este demonstra

\footnotetext{
${ }^{62}$ UFPA - Universidade Federal do Pará. Faculdade de Letras. Belém - Pará - Brasil. 66045-580 regina@ufpa.br
} 
fenômenos linguísticos presentes no português brasileiro semelhantes ao português de Angola e português de Moçambique, mas estigmatizados quando empregados no português brasileiro. A exemplo da proposta, o estudo evidencia traços linguísticos verificados por Chavagne, (2005:112) e Laban (1999:85) no nível fonológico, como a presença de metátese: prespetivas, pruguntar, dromir; assimilação: bibida, dispois, vistido, pidir; bem como aspectos no nível morfossintático em ocorrências como: ausência de artigo diante de possessivo, ausência de plural, redução da flexão verbal em favor da $3^{a}$ pessoa, irregularidade na concordância de gênero entre outros fenômenos também no nível lexical e léxico-sintático ( $c f$. Petter in Galves, Garmes \& Ribeiro, 2009:159-173).

Neste mesmo estudo sobre os aspectos linguísticos comuns entre o português angolano, o português moçambicano e o português brasileiro Petter assinala que:

São tantas as semelhanças compartilhadas pelas três variedades de português nos três níveis de organização linguística selecionados (fonológico, lexical e morfossintático) que fica difícil defender que tais fatos sejam casuais, resultantes de uma deriva natural do português ou decorrentes da manutenção de formas antigas do PE. [...] A hipótese de que essas mudanças tenham sido introduzidas por falantes de línguas africanas [...] mesmo que se considere que no Brasil falantes de línguas indígenas e de outras línguas europeias tenham participado da constituição do PB. (in Galves, Garmes \& Ribeiro, 2009:169)

$\mathrm{Na}$ mesma direção dos estudos afro-brasileiros, a perspectiva de um continuum afro-indígena na formação do português brasileiro é fortemente provocada ao considerar o histórico de contato entre nações indígenas e africanas em solo brasileiro. A literatura tem apontado nesta direção já em estudos de Amaral (1920) e Gladstone Chaves de Melo (1946:62), em cuja discussão caminha para o entendimento de um dialeto caipira de São Paulo ter sua base em um "tupi-quimbundo" ( $c f$. Pessoa de Castro, 2009:182).

A circunstância de um português afro-indígena pode ser verificada nesta seção no qual procuramos sintetizar em um gráfico convergente, as variedades morfossintáticas do português falado em Siricari (quilombo), ao lado de variedades [+ marcadas] do português étnico Ãpyãwa (aldeia) e do português afro-brasileiro de Helvécia. A proposta deste quadro é ter uma visão de conjunto relativo às semelhanças 
morfossintáticas do português falado em Siricari comparado às variedades na fala de outras comunidades. Lembramos que Helvécia, apesar de tratar-se de uma comunidade quilombola, traz indícios de um português procedente de crioulização (cf. Lucchesi, 2012:91) e que o português Ãpyãwa trata-se de $\mathrm{L}_{2}$.

Uma breve ressalva se faz necessária para o fato de que, a localização de Helvécia (nota 54 - pág.70) nos mostra que esta comunidade esteve envolta a grupos indígenas desde os anos oitocentistas, prevalecendo os povos Masakari, Pataxós, Botocudo e Tupinambá. Este último de maior incidência em grande parte da costa litorânea brasileira (cf. mapa etno-histórico do Brasil baseado em estudos de 1944 de Curt Nimuendaju in biblioteca.ibge.gov.br).

Gráfico 2: Variedades morfossintáticas do português falado nas comunidades Siricari, Ãpyãwa e Helvécia

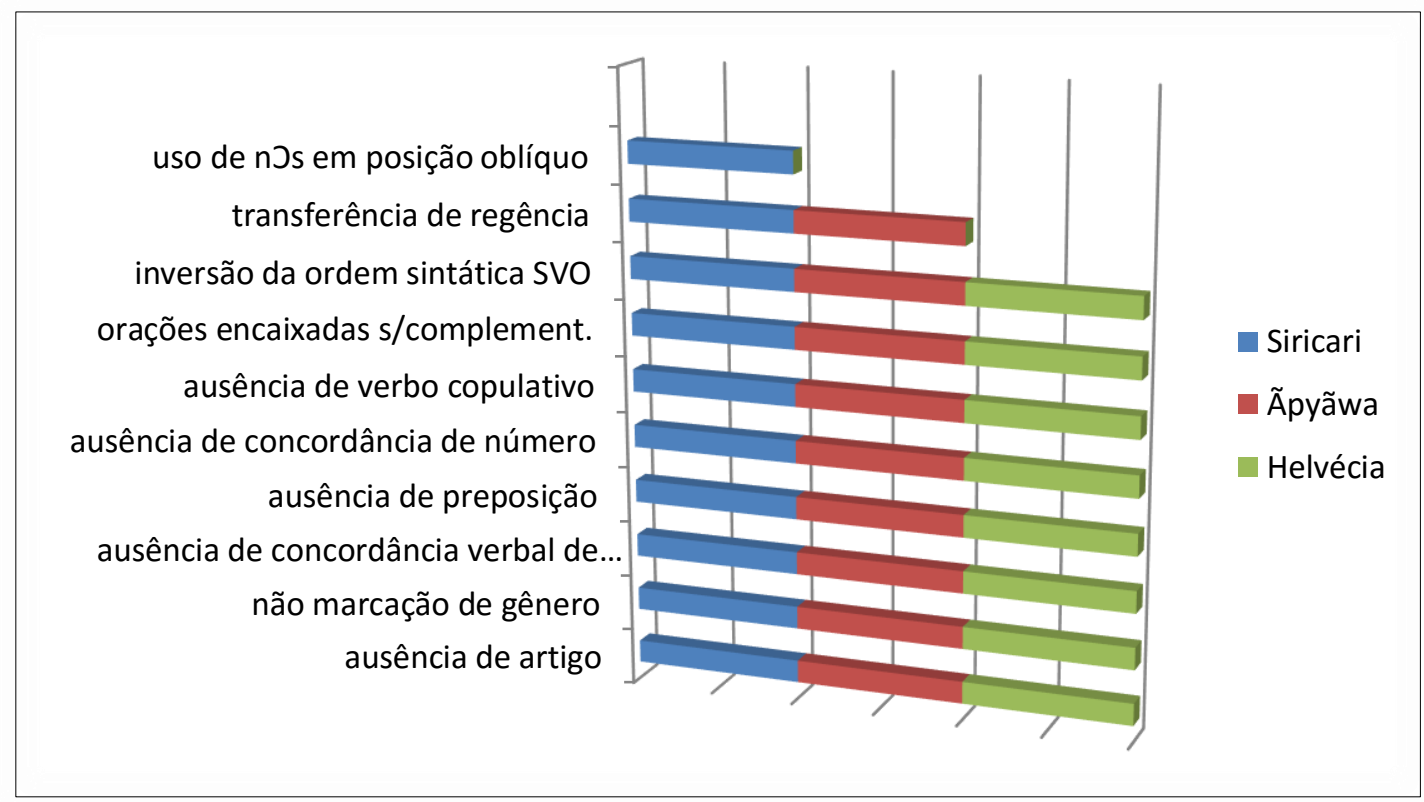

Estudos envolvendo o português afro-brasileiro e o português indígena têm demonstrado que a aquisição do português como segunda língua pelos descendentes africanos e indígenas provocou mudanças significativas na morfossintaxe e reestruturações de marcas gramaticais específicas do português. ( $c f$. Avelar \& Galves, 2014; Mattos e Silva, 1988). Nesse sentido, as similaridades morfossintáticas cotejadas neste tópico reforçam a hipótese de que variedades [+ marcadas] obtidas em estudo de campo em Siricari sugerem uma situação de contato entre negros, índios e brancos existida no passado, permitindo-nos, portanto, inseri-la no continuum Afro-Indígena do português brasileiro dada à sua constituição etnolinguística. 
Apesar de até aqui trabalharmos com as semelhanças entre o português falado em Siricari e o português étnico indígena, afro-brasileiro e afro-indígena, os tópicos seguintes demonstram variações específicas de Siricari. No entanto, não temos a pretensão de afirmar que são eventos únicos desta comunidade, embora até o momento, sem referência na literatura para possível confronto.

\subsection{Alternância vocálica $<$ u:o $>$ e $<$ i:e $>$ entre $1^{\text {a }}$ e $3^{\text {a }}$ pessoas do singular}

Nesta seção demonstramos haver uma alternância vocálica envolvendo os pares $<\mathrm{u}: \mathrm{o}>\mathrm{e}<\mathrm{i}: \mathrm{e}>\mathrm{em}$ formas verbais para posição tanto de $1^{\mathrm{a}}$ pessoa do singular, quanto de $3^{\mathrm{a}}$ pessoa do singular, como eu (fui, foi), ele (foi,fui).

Conforme demonstrado na sessão (3.1.9), a ausência de concordância verbal de primeira pessoa do singular na comunidade Siricari aqui renumerados em (44) a (47) poderiam indicar uma variação decorrente da mudança do quadro pronominal.

(44) Ele vem, faz a nossa comida, nós come. (SR-07)

(45) Eu teve onze filhos. (SR-08)

(46) Eu fez parto de criança que nasceu de bunda. (SR-05)

(47) Eu foi pra Belém de avion. (SR-08)

Entretanto, os dados obtidos em Siricari nos mostram uma peculiaridade: a ocorrência de verbos no pretérito perfeito do indicativo em cujas formas é possível haver alternância vocálica de $<$ u:o $>$ e $<$ i:e $>$ entre primeira e terceira pessoas do singular. De tal modo, percebemos o emprego das formas fui:foi e fiz:fez em alternância entre primeira e terceira pessoa do singular tal como: (i) (eu, ele) foi, fui; (ii) (eu, ele) fez, fiz.

Essa variação se estende, também, para o verbo ter nas formas tive:teve, prevalecendo apenas o emprego de ambas as formas verbais para a primeira pessoa pronominal do singular tal como: (eu) tive, teve. E o mesmo com o verbo estar, havendo redução das formas estive > tive e esteve > teve prevalecendo, por analogia, assim como o verbo ter, o emprego de ambas as formas verbais para a primeira pessoa pronominal do singular como em: (eu) tive, teve. Em se tratando da posição de terceira pessoa 
pronominal, o emprego da forma verbal segue a norma (ele/a) teve, igualmente para a forma reduzida em esteve, (ele/a) teve.

\subsubsection{Alternância vocálica $<$ i:e $>$ das formas verbais tive:teve}

Os registros com alternância vocálica utilizando as formas tive:teve irão ocorrer apenas diante da primeira pessoa do singular $e u$, como exposto nos exemplos (48) e (49).

(48) Tenho. Eu teve onze filhos.(SR-08)

(49) Quando eu teve trabalhando lá na delegacia [ININT] diz "fala com o prefeito pra botá uma professora pra cá, que num tem, essas criança tão tudo aí sem podê por onde ir estuda”.'(SR-02)

O ponto que chama a atenção é a redução das formas estive:esteve como no exemplo (49). De maneira semelhante ao verbo ter (48) a flexão de primeira e terceira pessoa do verbo estar adquire outro formato. Ambos os verbos ter e estar apresentam as mesmas formas: tive e teve, variando ora eu tive, ora eu teve. Não houve registros em terceira pessoa com a forma tive, como em (ele tive).

Vale assinalar que é possível identificar esse tipo de configuração do verbo estar nas formas tive:teve também na fala de indivíduos escolarizados e habitantes de centros urbanos.

\subsubsection{Alternância vocálica < i:e > das formas verbais fiz:fez}

Neste tópico demonstramos a alternância vocálica em posição de primeira e terceira pessoa do singular, em três situações: (i) com a presença do sujeito referencial, (ii) com distanciamento do referente e, (iii) diante a omissão do referente.

Inicialmente chamamos a atenção para os exemplos a seguir (50), (51) e (52) relativo à posição das formas verbais e seu referente pronominal. Os registros exibem tanto uma posição direta quanto diante de supressão pronominal, conforme demonstrado em (50). Nesse caso, é possível a recuperação do sentido via anáfora ou catáfora.

(50) Aí foi assim, aí eu fez um voto com Deus, entendeu? $\emptyset$ Fez um voto com Deus, eu fez esse voto. Aí eu pedi pra Deus. Aí na hora 
assim que... eu senti que a minha respiração tava assim tão pequenininha, aí eu senti um aperto aqui, na verdade eu ia sofrendo um enfarto. (SR-05)

A forma verbal de $3^{\mathrm{a}}$ pessoa 'fez' reporta-se a um pronome de $1^{\mathrm{a}}$ pessoa 'eu'. $\mathrm{O}$ uso do verbo em $3^{\mathrm{a}}$ pessoa em presença de pronome de $1^{\mathrm{a}}$ pessoa, conforme mostrado na sessão 3.1.9, tem sido observado também em outras comunidades com histórico de contato. No entanto, o contrário disso, a forma verbal em $1^{\mathrm{a}}$ pessoa 'fiz' reportar-se à $3^{\mathrm{a}}$ pronominal 'ele', parece-nos ser um fenômeno pouco observado. Esse fenômeno foi registrado em Siricari em mais de um informante, como ilustra o registro abaixo:

(51) [...] aí vim mimbora, quando eu cheguei aqui essa casa velha era grande, né, aí esse filho aí dirmanchô fiz ela menor e aqui eu estô, né, vivendo aqui tranquila, graças a Deus . [...] aí eu vim mimbora ele diminuiu mais a casa, aí fiz a 'zinha' dele aqui no lado, ai a gente dorme por aqui, né.(SR-07)

A proposição faz alusão ao neto da informante, referenciado por ela como 'esse filho', no qual sintaticamente marca a posição de sujeito. Então temos a estrutura transcrita da seguinte forma:

[...] aí eu vim embora. Quando eu cheguei aqui, essa casa velha era grande, né. Aí esse filho aí desmanchou (e) fez ela menor. E aqui eu estou, né, vivendo aqui tranquila, graças a Deus. [...] aí eu vim embora. Ele diminuiu mais a casa e fez a 'zinha' dele aqui no lado. Aí a gente dorme por aqui, né.

Em situações no qual há distanciamento ou supressão do referente pronominal ele, como evidenciado tanto em (51) [...] aí vim mimbora, quando eu cheguei aqui essa casa velha era grande, né, aí esse filho aí dirmanchô fiz ela menor e aqui eu estô, né, vivendo aqui tranquila, graças a Deus . [...] aí eu vim mimbora ele diminuiu mais a casa, aí fiz a 'zinha' dele aqui no lado, aí a gente dorme por aqui, né.(SR-07) como também em (52) depois $\emptyset$ fiz a casinha dele, parece-nos haver um acordo interacinal no qual a compreensão semântica se recupera por meio do contexto:

(52) [...] gostava muito... Deus oh livre, trabalhavam junto, logo ele morô aqui junto, depois $\emptyset$ fiz a casinha dele, [ININT] velho, né, ficaram velho junto, tanto [ININT] barranco, né, por isso tá tão bonito assim, né, aquele velho,né. (SR-10)

'... depois ele fez a casinha dele (já estava) velho, né, ficaram velho juntos...' 
Em busca de explicações para os eventos tratados em (3.3.1) e (3.3.2) revisitamos Naro e Scherre (2010:92) nos quais "garimpando" a dialetologia portuguesa europeia, descrevem variações registradas por Peixoto (1968:133) em meados do século XX. Os registros referem-se à Germil, vila localizada na região de Braga, norte de Portugal. Nesse estudo, os autores demonstram o emprego verbal de terceira pessoa do singular diante de primeira pessoa pronominal nos verbos ser, estar, ter, fazer e pôr no pretérito perfeito do indicativo. Assim expostos: eu foi, eu esteve, eu fez, eu pôs. Conforme se investigou, a ocorrência inversa como em ele fui é considerada rara.

Sobre a incidência desse tipo de variante (pronome em $1^{\mathrm{a}}$ p.sg e flexão em $3^{\mathrm{a}}$ p.sg) na fala de comunidades brasileiras, Naro e Scherre (2010:93) apontam que:

Esse tipo de neutralização também observado na fala de comunidades isoladas brasileiras e arrolado como um dos argumentos para identificar a existência de crioulização no português brasileiro (Ferreira, 1994:29-30, Baxter \& Lucchesi, 1997:77) ou para evidenciar a influência de processos de aquisição do português como segunda língua ou como língua estrangeira [...] é um fenômeno perfeitamente encaixado na configuração geral do português.

Para estes autores, "as evidências tratadas no português não padrão europeu são suficientes para dar conta da gênese do português brasileiro, não existindo justificativa para buscar outras fontes mais distantes" (2010:114)

Notadamente as evidências linguísticas do português europeu não padrão partilham das mesmas variedades verificadas em comunidades brasileiras conforme temos demonstrado. Contudo, essas evidências não podem significar uma extensão da variante europeia sobre as comunidades brasileiras. Reconhecemos a viabilidade de variações comuns entre o português europeu e o brasileiro, mas isso não significa que compartilhamos da abordagem de que "a origem primeira dos fenômenos variáveis de concordância veio de Portugal" conforme postulado em Naro \& Scherre (2010:50-52). Isso porque seria um contrassenso desconsiderar todo o contexto social, linguístico e cultural que faz parte da constituição linguística no Brasil. Conforme observou Lopes (1988:86), nas línguas bantas, por exemplo, “o sujeito vem antes do verbo, o complemento vem após o substantivo, o verbo vem antes do objeto direto, etc., tal qual na língua portuguesa". 
O modo como ocorreu a imposição da língua portuguesa em terras brasileiras e a diversidade linguística constante em Marajó ainda no século XIX, nos leva mais uma vez à defesa de que é razoável considerar a existência de fenômenos linguísticos provenientes do contato entre as línguas mantidas no período colonial, seja ela de origem indígena ou africana ou ambas. Seria no mínimo estranho pensar que falantes de línguas indígenas, sobretudo de língua geral e de línguas africanas (crioulas ou não), adotaram a língua portuguesa sem deixar qualquer resquício de sua língua primeira.

São diversos os estudos que apontam a relação de línguas africanas no português brasileiro. Um dos estudos é a proposição de semi-crioulização no português do Brasil adotada por Holm (1992 apud Bonvini, 2008:54). Em sua defesa a favor de uma semicrioulização no português brasileiro este linguista aponta os principais traços que indicam essa possibilidade:

a) na fonologia: estrutura silábica $\mathrm{CV}$, processo de desnasalização, palatalização, alternância de 1 e r;

b) na morfologia: flexão verbal reduzida, ausência de concordância sujeito-verbo, marca de número no primeiro termo do sintagma nominal,

c) na sintaxe: marca pré-verbal; predicação não verbal, dupla negação, focalização do predicado, equivalência reflexivo/ passivo, redobro, ter e estar, falar p'a, preposições ni, na, Ø.

Conforme temos demonstrado em (3.1.9) e (3.3) alguns fenômenos verificados em Siricari se assemelham à configuração do português étnico indígena. Em Nheêngatú, língua geral falada ainda em localidades do norte do país (São Gabriel da Cachoeira) temos icú, verbo ser ou estar, regular para todas as pessoas pronominais, onde se nota: Cha icú ana, Re icú ana, Hu icú ana, Yá icú ana, Pe icú ana, Hu icú ana, sendo os termos ana, indicativo do aspecto perfectivo, e $C h a, R e, H u, Y a ́, P e, H u$, referente às pessoas pronominais. ( $c f$. Símpson, 1955).

Além dessa "regularização" de terceira pessoa verbal, mais um ponto importante a ser considerado é o que expõem Lucchesi \& Baxter (2009:337) acerca da concordância verbal com a primeira pessoa pronominal do singular, apontando para 
diversos estudos nos quais a manifestação da terceira pessoa verbal é tida como default sobre as demais pessoas:

No processo de transmissão irregular que afetou a formação do português afro-brasileiro, as marcas de pessoa e número teriam sofrido, em todas as pessoas do discurso, uma forte concorrência da forma não marcada da $3^{a}$ pessoa do singular [...]. Em estudos de aquisição do espanhol como segunda língua, observa-se que, na interlíngua, a $3^{\text {a }}$ pessoa do singular serve como default ou forma subespecificada (ANDERSON, 2002, p.91; CLEMENTS, 2003; BRUHN DE GARAVITO, 2003; McCARTHY, 2006). Também estudos da aquisição monolíngue de catalão (DAVIDSON; OLDRICK, 2003), espanhol (RADFORD; PLOENNING-PACHECO, 1995) e português (SIMÕES; STOEL-GAMMON, 1979) apontam para o uso da $3^{\text {a }}$ pessoa do singular como default. Em variedades do português da África, também há evidências da variável generalização da $3^{\text {a }}$ pessoa do singular do verbo (BAXTER, 2002, p.18-19; GONÇALVES; STROUD, 1998, p.123; MENDES, 1985, p.149-151).

Deste modo, embora tenhamos semelhanças evidentes no emprego da forma verbal de $3^{\mathrm{a}}$ p.sg em posição de $1^{\mathrm{a}} \mathrm{p}$ pronominal.sg em variantes do português europeu, não se pode negar as evidencias do português brasileiro com línguas indígenas e africanas.

\subsubsection{Alternância vocálica $<$ u:o $>$ das formas verbais $f u i$ :foi}

Neste capítulo descrevemos a alternância vocálica $<$ u:o > em posição de primeira e terceira pessoa do singular, em situações que nos parece peculiar quando se refere ao emprego das formas fui:foi como em: eu (fui:foi), ele (fui,foi). O emprego dessa variante é sobremaneira habitual na fala de diferentes informantes em Siricari. Indiscriminadamente, podemos assinalar quatro, em cada cinco informantes empregam essa variante, independente do nível de escolaridade e idade.

A posição das formas fui:foi não é fixa. Ela pode vir precedida de um pronome como em (53) ou distante, como demonstrado em (54). 
(53) Tudo non, que uma menina, a última, eu foi pra Belém de avion, de Sore, cá criança, passei três dia ca criança morta nas ventas.(SR-08)

(54) Eu também inda foi de pé, depois que eu cresci, inda foi de pé atrás do pexe. (SR-04)

Nesse caso a alternância das formas fui:foi não chega a comprometer o sentido e é rapidamente compreendida em função do pronome que antecede o verbo. Entretanto, quando a alternância ocorre sem uso do pronome referenciador, como demonstramos seguir em (55), o entendimento pode se tornar equivocado, uma vez que se tem cristalizada a interpretação de primeira (fui) ou terceira pessoa (foi) a partir dos aspectos morfológicos do verbo.

(55) Um dia mandaro ela vê num sei o quê, lá onde a mãe do João morava, ela fui sozinha, né, aí fui embora. Quando ela já vinha de volta, ela viu pra trás 'psiu'. (SR-10)

Ou seja, a forma verbal fui sugere o entendimento de que se trata de falante em $1^{\text {a }}$ pessoa. No entanto, ao analisar a estrutura da sentença: ela fui sozinha, né, aí fui embora, temos o sujeito ela, agente da situação de 'ir sozinha', bem como agente da ação de 'ir embora'. Assim, podemos interpretar como ela fui sozinha/ela fui embora.

Esse fenômeno se repete nos registros seguintes numerados em (56) e (57), e chamam a atenção para a semelhança da formulação articulada por pessoas e momentos diferentes, sendo que no primeiro registro o falante reconstrói a sentença numa tentativa de reforçar o enunciado.

(56) [...] contava que, que aqui já fui fazenda, né, que aqui já tinha sido fazenda que ele nós contava, né esse terreno aqui ele é grande. (SR-10)

(57) Aí ele tinha gado aí, cavalo, aqui já teve... já fui fazenda, senhora olhava, quando eu vim pra cá a gente olhava ali da casa do meu conhado que era assim de soalho alto, a gente enxergava lá o fim quase do terreno, era. (SR-08)

Quando nos deparamos com o próximo registro (58), inicialmente demoramos um tempo para reconhecer o legítimo agente da ação de crescer: 

num se arredô pra nem um canto. Ele trabalha só por aqui mesmo, num trabalha longe de mim. (SR-07)

A interpretação do enunciado nos foi igualmente surpreendente. Percebermos que a relação entre a ação e o agente não se trata de $1^{\text {a }}$ pessoa ...e fui crescendo, fui crescendo, ou seja, não faz alusão à locutora avó, mas sim ao referente pronominal "ele", objeto que está sendo tratado desde o início do enunciado, portanto, condizente ao neto da informante. Em outras palavras: "fui crescendo ele", tal como ocorre no português indígena e moçambicano.

Diante do exposto, é evidente a relação pragmática nesse enunciado uma vez que para se obter a compreensão o ouvinte deve ir muito além das relações morfossintáticas imbuídas na estrutura frasal.

Apesar de presumir relações linguísticas de ordem pragmática, na expectativa de buscar elementos linguísticos que pudessem esclarecer, em parte, o fenômeno da alternância nas formas verbais fui:foi como demonstrado anteriormente, chegamos a um artigo de Mattoso Câmara (1943), intitulado "A alternância portuguesa 'Fui:Foi'” no qual esclarece que:

Dois fatos citados das falas populares indicam, antes de tudo, um estado de indiferença no jogo flexional fui:foi, visto que ora se empregam "ambas as formas nas duas pessoas", ora se invertem elas, usando-se "de Foi na $1^{\text {a }}$, e de Fui na $3^{\text {a }}$, e tal situação é também apreensível na língua antiga [...]. Com efeito, num documento de 1262, por exemplo, depara-se-nos expressivamente:

"Esta carta fui iij dias antes calendas Novembris su era $\mathrm{M}^{\mathrm{a}} \mathrm{CCC}$ e V" (p.278)

E aponta que o mesmo se verifica nos documentos galegos e na poesia da escola provençal:

\footnotetext{
"a auer deuo por uoz de meu padre Johan Çacoto, que ffuy filho de Maria Crualliça...”

“...non lhe empeesca porque uay escrito so o sinal, que ffuy erro"
} 
“que non fui o vosso pesar...” (Mattoso Câmara, 1943:278)

Para essas ocorrências, Mattoso Câmara (1943) procura esclarecer a origem da alternância ora apresentando fatores sincrônicos, ora diacrônicos e assinala que:

Durante algum tempo, a consciência linguística coletiva se conformou com essa confusão, ora usando-se (eu, ele) foi, ora (eu, ele) fui, mas a "tendência para o contraste vocálico entre as duas pessoas" [...] não tardou a impor uma distribuição sistemática das duas formas, na maioria dos dialetos portugueses e na língua literária ou comum. (p.285)

Em um primeiro momento, a hipótese de vestígios de uma estrutura linguística quinhentista em Siricari nos pareceu bastante tentadora. Entretanto, diante da declaração de Mattoso Câmara (1943:286) de que houve ao longo do tempo uma "distribuição sistemática das duas formas" e, também, da afirmação de Naro e Scherre (2010:92) de que raros são os registros contendo o emprego de primeira pessoa verbal diante de terceira pronominal ele fui, ele fiz no português não padrão europeu, abandonamos essa perspectiva e buscamos outros fatores que pudessem ser mais esclarecedores.

Estudos de Lucchesi, Baxter e Ribeiro (2009:336) assinalam que, embora escassos, há registros que apontam para a presença variável do morfema de primeira pessoa do singular em textos de tradições orais afro-brasileira, como na lírica do jongo, registrado por Ribeiro (1968:198-199) na década de 1950; no lundu do Pai João (Lopes, 1988) e nos vissungos de São João da Chapada, em Minas Gerais, registrado por Machado Filho (1985) na década de 1930. No entanto, a variação apresentada nos cantos refere-se apenas a primeira pessoa pronominal, como se vê em Lopes (1988:171), Quando iô chega na terra de baranco, iô mi chama Pai João [...], e em Machado Filho (1885:80), Eu memo é capicoite, eu memo é cariocanga [...].

O que podemos perceber é que: (i) a variação em primeira pessoa, como apontado no item (3.1.9) parece apontar para um padrão verbal de terceira pessoa em Siricari e nas comunidades africanas e indígenas aqui arroladas; e (ii) a variação de terceira pessoa verbal diante de primeira pronominal, como mostrado em (3.3.2) e (3.3.3), em termos de Brasil tem se mostrado, até onde nós sabemos, uma peculiaridade na fala de Siricari. Diante disso, entendemos que esse fenômeno merece maior 
investigação, tanto em busca de registros semelhantes em outras comunidades brasileiras, quanto aprofundamento no campo da fonologia.

\subsection{Presença de verbo em final de frase: um possível caso de modalidade epistêmica}

Nesta seção mostramos um aspecto bastante expressivo observado em Siricari, que consiste da ocorrência das formas verbais era e foi em final de sentença. Não encontramos na literatura uma definição direta a esse tipo de estrutura frasal, tampouco a ocorrência deste fenômeno linguístico em estudos de comunidades afins.

\subsubsection{Modalidade epistêmica do verbo ser em final de frase}

Por não encontrarmos na literatura qualquer evento parecido com o que descrevemos nesta seção, o desafio consistiu em buscar teorias que pudessem esclarecer que tipo de fenômeno linguístico está presente neste modo de expressar em Siricari. Pelo o que constatamos, parece tratar-se de um evento relacionado à modalidade epistêmica, uma vez que as formas era e foi em final de sentença parecem expressar a atitude do falante em relação ao que foi dito.

É provável haver um esvaziamento da função de verbo pleno quando as formas era e foi estão fixas no final de sentença. Esses elementos parecem figurar como partículas modais. Consideremos, até aqui, como verbos externos ao enunciado. Vejamos as ocorrências a partir dos seguintes exemplos.

(59) Meus avós memo eu num conheci, né, foi. (SR-10)

(60) Porque quando eu vim mimbora pra cá que eu recomperei muito bem, nós devolvemo o dinhero dele. Devolvemo! Mas gente já devolvemo pro Tonga, foi. (SR-08)

O pretérito perfeito do indicativo no verbo devolver, interno à sentença (60), traz a ideia de término, cessação do evento. Todavia, a forma verbal externa foi, também no pretérito perfeito, denota uma relação de certeza, de garantia, ou mesmo convicção daquilo que está sendo dito, muito além do que um aspecto terminativo, como se vê em 'devolvemo'. 
Conforme demonstrado, ao longo do enunciado nos exemplos (59) e (60) os tempos verbais estão no pretérito perfeito e coincidem com o "tempo" da forma foi em final de frase, apesar de aventada por nós como não-temporal. É curioso que em todas as ocorrências observadas o falante constrói o período ajustando a forma foi, em final de sentença, com verbos alocados no pretérito perfeito.

Quando se trata da forma era em final de sentença, como ilustrado a seguir em (61) e (62), o falante faz uso de verbos internos do enunciado no pretérito imperfeito do indicativo.

(61) Por mês? Ganhava trinta merréis, duas panela de farinha, dois quilo de açúcar. Por mês, era. (SR-02)

(62) A senhora olhava assim, parecia que era criança de cinco anos, era. (SR-05)

Apesar de denotar mesmo tempo verbal (pretérito imperfeito) em se tratando de (61) ganhava e era, (62) olhava e era (verbos internos e externos respectivamente) ou, nos exemplos (59) conheci e foi, (60) recomperei e foi (verbos internos e externos respectivamente), o valor atribuído a cada uma das formas verbais de final de frase (era e foi) não condiz com uma interpretação aspectual ou temporal, mas a uma expressão epistêmica como defendemos adiante.

Ao considerarmos anteriormente o exemplo numerado em (61) Por mês? Ganhava trinta merréis, duas panela de farinha, dois quilo de açúcar. Por mês, era. (SR-02), o verbo interno 'ganhava' traz a noção de imperfectivo considerado pela gramática tradicional como ação habitual ou contínua. Todavia, não se pode conferir o mesmo valor à forma era inserida no final da sentença. O que ocorre é que o falante imprime em sua narrativa uma aproximação do que está sendo dito sobre o evento, não necessariamente os fatos da narrativa são exatos, mas mais ou menos deste jeito.

A partir desse fato, recorremos a Palmer (2001) cujo estudo distingue tempo, aspecto e modalidade. $\mathrm{O}$ autor assinala que "modalidade é uma categoria gramatical geral distinta de tempo e aspecto por não se referir a nenhuma característica do evento, mas simplesmente ao status da proposição". O tempo remete ao 'tempo' do evento; o aspecto à natureza do evento, particularmente, à constituição temporal interna, conforme Comrie (1976, apud Palmer 2001). E modalidade refere-se ao status da proposição que descreve o evento. Para Palmer existem dois sub-grupos para 
modalidade: a) proposicional, que refere à modalidade epistêmica e modalidade evidencial; e b) de evento, relativo à modalidade deôntica e modalidade dinâmica. No que se refere ao presente tópico, interessa-nos o item (a) por conter elementos de que vamos tratar.

Um dos confrontos interessantes que vale a pena discutir é a relação entre evidencialidade, marcação da origem das informações da declaração; e modalidade epistêmica, grau de confiança que o falante tem em sua proposição ( $c f$. Haan, 2000). Ambas as modalidades estão ligadas a atitude do falante em relação ao valor da verdade ou ao status factual da proposição, mas notemos a diferença entre elas.

Para Aikhenvald (2006:320),

Evidencialidade é uma categoria gramatical que tem como origem da informação o seu significado primário - se o narrador realmente viu o que está sendo descrito, ou se faz inferências sobre o fato com base em alguma evidência direta ou indireta, se foi dito algo sobre o fato, etc.

No mesmo caminho, Hann (2000:3) descreve evidencialidade como a origem da evidência revelada pelo falante em sua declaração e explica que:

Evidencialidade é dividida em evidencialidade direta e indireta. Evidenciais diretos são usados quando o falante tem testemunhado a ação (visualmente, auditivamente, ou potencialmente, com os outros sentidos), enquanto evidenciais indiretos são utilizados quando o falante não tem testemunhado a ação pessoalmente, mas tem deduzida a ação ou já ouviu falar sobre isso a partir de outros. Quando a ação é deduzida chamamos inferentials, quando as informações sobre o evento é transmitido através dos outros, eles são chamados quotatives.

Em Palmer (2001:8) temos a fronteira entre modalidade epistêmica e evidencialidade

A diferença essencial entre estes dois tipos é que, com a modalidade epistêmica o falante expressa seus julgamentos sobre o estado factual da proposição, enquanto com a modalidade evidencial o falante indica evidências que ele tem para o status factual da proposição. 
Diante dessas definições podemos sintetizar que evidencialidade remete a elementos inferenciais, sensoriais de que o falante utiliza para a proposição. Ou seja, a declaração compõe evidências daquilo que foi visto, sentido ou ouvido. Para um melhor exame dessa prática, Aikhenvald (2006:322) demonstra que as evidências podem ser marcadas ou não-marcadas, assim:

a) Manuel comeu (o falante viu isso)

b) Manuel comeu (o falante viu o prato sujo)

c) Manuel comeu (o falante sabe que Manuel sempre come às $8 \mathrm{~h}$ e agora eram 9h)

No entender de Palmer (2001), o uso do pretérito nas modalidades epistêmicas "são essencialmente subjetivas, não são usadas nas formas do tempo passado para indicar um julgamento passado”. Para ele modalidade epistêmica “[...] diz respeito unicamente à atitude do falante para o valor da verdade, ou status factual da proposição" (págs. 76 e 86).

Pelo que tudo indica a definição de modalidade epistêmica tratada por Palmer vai ao encontro das formas verbais era e foi obtidas no português falado em Siricari. Ambas as formas se encontram no pretérito e também não indicam tempo passado, mas um recurso gramatical utilizado pelo falante para expressar sua atitude diante da proposição. Entretanto, não explica o fato de haver duas formas verbais foi e $e r a$, como visto em Siricari.

Embora a literatura traga amplos estudos acerca de modalidade epistêmica (Palmer, 2001; Hann, 2002; Longhin-Thomazi, 2006; Bybee, 1995), revisitamos a proposta dos tipos realis e irrealis em Givón (2001:300), cuja definição se aproxima do valor modal que melhor condiz com os dados obtidos em Siricari.

A vertente epistêmica descrita por Givón (2001) contém algumas diferenças. Ela é indicativa do grau de certeza do falante atinente à verdade, probabilidade, certeza e evidência, e estão distribuídas em quatro sub-tipos:

a) presupposition: toma-se como certo de que a proposição é verdadeira por definição, acordo prévio, convenção compartilhada culturalmente, por estar óbvio para todos na situação de fala, ou por ter sido proferida pelo falante e incontestada pelo ouvinte. 
b) realis assertion: a proposição é defendida fortemente como verdadeira, embora seja admissível uma contestação, o falante ter evidências ou bases sólidas para defendê-la.

c) irrealis assertion: a proposição é fracamente afirmada como possível, provável ou incerta (sub-modos epistêmicos), ou necessária, desejada ou indesejada (sub-modos deônticos). O falante não está pronto para comprovar, dar evidências. A contestação do ouvinte é prontamente recebida, esperada ou até mesmo solicitada.

d) negative assertion: a proposição é fortemente afirmada como falsa, normalmente em uma contradição às crenças explícitas ou implícitas do ouvinte. A contestação do ouvinte é antecipada e o falante tem provas ou outros motivos fortes para fazer demonstrar sua crença.

Uma perspectiva entre os sub-tipos realis e irrealis é dada por Mithun (1999:173), o qual assinala:

$\mathrm{O}$ realis retrata algo que tenha ocorrido ou realmente esteja ocorrendo, perceptível através da observação direta. O irrealis retrata situações puramente dentro do reino do pensamento, perceptível só através da imaginação. (grifo nosso)

Como anunciado, os sub-tipos realis e irrealis, propostos por Givón, redefinem o fenômeno linguístico foi e era em final de sentença e, para aplicarmos esses conceitos à prática, tomamos o registro seguinte para análise.

(63) Aí ela não sabia quantos ano ela tinha, minha mãe num sabia. Quando ela já tava mocinha, já ela começô se abaseá pela idade dos otros, foi. Minha mãe faleceu dia 10 de junho, foi. Mas ela muito, muito já idosa, muito mesmo. (SR-05)

A narrativa contada pela filha permite notar que se trata de uma situação real, próxima ao falante, e indiscutível do ponto de vista factual. A situação de parentesco direto com o sujeito da narrativa faz com que o falante seja a pessoa mais apta a tratar o assunto exposto. Uma possível demonstração do comprometimento do falante com a proposição expressa. Neste caso, o falante é quase categórico, cerceia qualquer 
contestação, haja vista sua posição de filha, detentora e conhecedora dos fatos pertinentes à sua mãe.

Nesse exemplo, entendemos que a frequência da expressão foi, empregada uma vez ao término de cada uma das três sentenças, tenha o intuito de afiançar a veracidade do que está sendo dito. Assim, configurando uma modalidade epistêmica do sub-tipo realis, cuja definição aponta para uma proposição "defendida fortemente como verdadeira, embora seja admissível uma contestação, o falante tem evidências ou bases sólidas para defendê-la" (Givón, 2001)

Em todos os eventos pelos quais demonstramos o uso da expressão foi em final de sentença percebemos uma força discursiva garantidora da veracidade daquilo que foi proferido. O falante está tão convicto da proposição que, caso haja alguma contestação, ele facilmente apresentará elementos que comprovem a verdade dos fatos. A proposição sugere ser o falante detentor dos fatos e, como tal, não há o que questionar.

Já o outro tipo de proposição verificada em Siricari é o emprego da expressão era em final de sentença. Este tipo de proposição também está presente naturalmente na fala dos informantes e sucede ao uso de verbos plenos no pretérito imperfeito do indicativo. Consideremos o exemplo em (64) para exame:

(64) Ele só era guiado quando ele ia por uma parte assim ele era guiado, mas de dentro de casa, a casa que ele é acostumado andava tudinho. Tocava um violão que era uma beleza. (SR-10)

Era músico, era. (SR-04)

Tocava violão, era. Ele era padrinho da Minê, da tua mãe, era. (SR-10)

O assunto abordado relata, de modo não expressivo, a história do pajé cego que viveu próximo à comunidade. Os fatos narrados são descritos de forma ilustrativa, há pouca expressividade ao apontar as qualidades do sujeito. Parece que o falante opta por qualquer atributo do sujeito, qualquer atributo que lhe vem à mente. Apesar disso, os fatos são verdadeiros.

A falta de pretensão na abordagem detalhada dos fatos incide, também, sobre narrativas que tratam da vida do próprio falante, como pode ser visto no exemplo abaixo: 
(65) Eu tava muito enferma, problema de coluna, e as viroses que tava dando né, e muita fortes dores no meu corpo, era. (SR-05)

Nessa amostra o falante não está bem certo do que estava sentindo, podia ser qualquer um dos fatores listados no discurso que justificaria a indisposição de atender à solicitação de ajuda em um parto, uma vez que o falante era a parteira da comunidade. O fato é que a 'indisposição' consiste do ponto forte da assertiva e esta é verdadeira. No entanto, os elementos indicativos da enfermidade, tratada na proposição, não importam fortemente. O falante hesita entre o "problema de coluna" e as "viroses", não sabe bem ao certo o que causava a indisposição. Esse fato não é essencial. Neste sentido, podemos dizer que a descrição dos problemas de saúde torna a assertiva fraca, pouco consistente do ponto de vista da certeza de qual era o problema de saúde que a narradora sofria naquele dia.

Isso nos leva a entender que o uso da expressão era em final de frase pode se tratar de uma propriedade do sub-tipo irrealis, definido por Givón (2001) como sendo uma "proposição fracamente afirmada como possível, provável ou incerta. O falante não está pronto para comprovar, dar evidências".

Esse tipo de assertiva no qual o falante demonstra menor comprometimento naquilo que diz, pode ser considerado por Koch (2008:86) como uma manobra discursiva do qual o falante deixa livre a possibilidade de o ouvinte aceitar (concordar) ou não o que foi dito. É facultativo. Conforme a autora, frequentemente esse tipo de situação é observada quando do emprego de expressões como é possível, eu acho, provavelmente, etc.

Uma reflexão bastante pertinente para pensarmos a linguagem e suas propriedades muitas vezes pouco evidentes está em um trecho de Benveniste (2005:287), no qual orienta que "a língua sem expressão da pessoa é inconcebível”. A individualidade, as sabedorias, as crenças e concepções de verdades; intersubjetividades alcançam a instância do discurso e (re)surgem na linguagem a partir dos mais variados modos. 


\section{CONSIDERAÇÕES FINAIS}

Nesta dissertação tivemos como enfoque descrever as variações linguísticas do português falado na comunidade quilombola Siricari. Em alguns momentos procuramos demonstrar elementos que envolvem o modo de falar da comunidade indo além da observação gramatical. Nesse caso, o estudo apresentou parâmetros linguísticos que podem estar relacionados a heranças de falares antigos, bem como resquícios de experiências de contato com outras línguas, a saber indígena e africana.

As investigações tratadas no capítulo 1 foram a base para incluir o português falado em Siricari no âmbito do Português Afro-Indígena. A ocupação da ilha no período colonial, bem como as histórias relatadas pelos antigos moradores da comunidade mostraram evidentes traços de miscigenação africana e indígena na configuração da comunidade. Essa miscigenação étnica vinculada a comportamentos sociais e culturais moldaram crenças que contribuíram na forma particular de pensar, agir e, consequentemente, no modo de expressar e de falar dessa comunidade.

As contribuições teóricas tratadas no capítulo 2 subsidiaram a hipótese inicial de que o português falado em Siricari poderia referir-se à elementos linguísticos contraídos do contato de gerações passadas. Essa perspectiva seguiu proposições atinentes ao Português Afro-Indígena discorrido na sessão 2.3, que sublinha a existência de particularidades gramaticais em comunidades envoltas à miscigenação afroindígena. Sob esse viés, procuramos demonstrar que em alguns dados linguísticos sugerem tratarse de marcas de contato de matriz africana e indígena.

Por fim, a descrição das variações do português elencadas no capítulo 3 autorizaram-nos a defender a proposição de que as variedades linguísticas apuradas em Siricari apontam para o eixo [+marcado] do continuum dialetal do português brasileiro. Esse ponto de vista teve por base as seguintes considerações:

a) os aspectos linguísticos do qual identificamos como [+marcados] possivelmente revelam traços de transferência linguística conservados no modo de falar da comunidade e devem ser sistematizados em suas minúcias, sobretudo em cotejo com a LGA. Isso porque, como retratado neste estudo à pág. $44,1^{\circ} \S$, a LGA se manteve fortemente ativa em todas as esferas sociais durante os três primeiros séculos de colonização. Esse fator, bem como as semelhanças demonstradas entre as variações na fala de Siricari e o 
português étnico indígena parece-nos contribuir para a hipótese de que os fenômenos linguísticos constatados neste estudo advêm de substratos de língua indígena, a saber da LGA.

b) fenômenos como a alternância vocálica entre $1^{\mathrm{a}}$ e $3^{\mathrm{a}}$ pessoas verbais, bem como a presença das formas era e foi em posição final de frase são eventos até então raros na literatura e, talvez, decorrente da relação etnolinguística contida na formação da comunidade Siricari.

Apesar de termos tido, inicialmente, a pretensão de analisar quantitativamente os eventos linguísticos obtidos na coleta de dados referente à comunidade Siricari, muitas foram as dificuldades para a composição do corpora. Apesar disso, a importante contribuição reconhecemos a contribuição deste estudo por fomentar novas investigações a partir da base de dados originais aqui demonstrada, bem como instigar discussões acerca dos eventos ainda não descritos na literatura, como mostrado nas sessões 3.3 e 3.4 .

Também, este estudo contribui para uma investigação maior sobre a variedade vernacular do português falado na região norte brasileira, de modo a poder confrontar com o português falado em outras comunidades de constituídas de matriz africana e indígena. Importa ressaltar que os registros aqui demonstrados em uma primeira análise são tratadas por nós como variações linguísticas passíveis de transferências por contato linguístico nos níveis gramatical e pragmático e mantidas pelas sucessivas gerações de falantes nativos da comunidade Siricari. 


\section{REFERÊNCIAS BIBLIOGRÁFICAS}

ACEVEDO MARIN, R. Quilombolas na Ilha de Marajó: Território e Organização Política. In: GODOI, E. P. D.; MENEZES, M. A. D.; ACEVEDO MARIN, R.

Diversidade o campesinato: expressões e categorias. São Paulo: Unesp, v. 1, 2009. Cap. 9, p. 209-227.

AIKHENVALD, A. Language Contact in Amazonia. New York: Oxford University Press, 2002.

AIKHENVALD, A. Y. Evidentiality in grammar, 2006. 320-324.

ANNAES da Bibliotheca e Archivo Publico do Pará. University of Florida Digital Collections, 1904. Disponivel em:

$<$ http://ufdc.ufl.edu/results/?t=arquivo\%20publico\%20do\%20para>. Acesso em: 11 junho 2015.

AVELAR, J.; GALVES, C. O papel das línguas africanas na emergência da gramática do português brasileiro. Linguística, Campinas, 2 dezembro 2014. 241-288.

BAENA, A. L. M. Ensaio Corográfico sobre província do Pará. Biblioteca digital do Senado, Brasília, 2004. Disponivel em:

<http://www2.senado.leg.br/bdsf/item/id/1097>. Acesso em: 11 junho 2015.

BAGNO, M. Português ou brasileiro, um convite à pesquisa. São Paulo: Parábola, 2001.

BAXTER, A. N. Transmissão Geracional Irregular na História do Português Brasileiro: divergências nas vertentes afro-brasileiras. Revista Internacional de Língua Portuguesa, v. 14, p. 72-90, 1995.

BAXTER, A. N. Creole-like features in the ver system of an afro-brazilian variety of portuguese. Creole Language Library, 19, 1997. 265-288.

BAXTER, D. L. E. A. Vertentes. Disponivel em: <http://www.vertentes.ufba.br/acomunidade-de-fala-de-helvecia-ba>. Acesso em: 10 nov. 2015.

BECHARA, E. Gramática Escolar da Língua Portuguesa. 2. ed. Rio de Janeiro: Nova Fronteira, 2010. 
BENVENISTE, É. Problemas de Linguística Geral. Tradução de Maria da Glória Novak e Maria Luisa Neri. 5. ed. Campinas: Pontes, 2005. 387 p. Revisão: Prof. Isaac Nicolau Salum.

BONVINI, E. Línguas africanas e o português falado no Brasil. In: África no Brasil. [S.1.]: [s.n.], 2008. p. 15-62.

BONVINI, E.; PETTER, M. Portugais du Brésil et langues africaines. Langages, Paris, v. 130, n. 32 - Larousse, p. 68-83, 1998.

BORGES, L. C.; HORTA NUNES, J. Les langues générales et la grammatisation des langues indiennes. Langages, Paris, Junho 1998. n. 130, p. 52-67.

BORTONI, S. M. A migração rural-urbana no Brasil: uma análise sociolinguística. In: (ORG.), F. T. Fotografias Sociolinguísticas. Campinas: Pontes: Universidade Estadual de Campinas, 1989. p. 167-180.

BYBEE, J. L. Modality in Grammar and Discourse (Typological Studies in Language). [S.1.]: John Benjamins Publishing Company, 1995.

CAMPOS, E. A. A sintaxe pronominal na variedade afro-indígena de Jurussaca: uma contribuição para o quadro da pronominalização o português falado no Brasil. São Paulo: USP, 2014. Tese de doutorado.

CASTILHO, A. T. D. Gramática do Português Brasileiro. 1a. ed. São Paulo: Contexto, 2012.

CENTRO de Memória da Amazônia. http: //www.ufpa.br/cma/documentos.html. Acesso em: 14 jan. 2016.

CHAVES, A. S. A ordem VS no português da fronteira. In: (ORG.), F. T. Fotografias sociolinguísticas. Campinas: Pontes, 1989. p. 65-79.

CHAVES, R. A formação da toponímia fluminese: a imposição da toponímia na capital do Rio de Janeiro. Simpósio de Geografia Urbana, Fortaleza, 8 a 12 setembro 2015. Disponivel em: <file://C:/Users/Cristiane/Downloads/2446.pdf>. Acesso em: 20 Janeiro 2016.

DOMENICO, U. D. Léxico Tupi-Português com aditamento de vocábulos de outras procedências indígenas. Taubaté: Universidade de Taubaté - UNITAU, 2008. 
ENGEVELD, K. Non-verbal predication: theory, typlogy, diachrony. Berlin - New York: Mouton de Gruyter, 1992.

FERREIRA, M. Descrição de Aspectos da Variante Étnica Usada pelos Parkatejê.

D.E.L.T.A., v. 21, n. 1, p. 1-21, 2005.

FILHO, A. D. M. M. O negro e o garimpo em Minas Gerais. Belo Horizonte: Itatiaia - USP, 1985.

FRANÇA, A. Tupinismos e africanismos na visão de Mattoso Câmara. III Encontro da Associação Brasileira de Estudos Crioulos e Similares. São Paulo: Universidade de São Paulo. outubro 2014. p. 1-7.

FREIRE, J. R. Rio Babel: a história das línguas na Amazônia. Rio de Janeiro: UERJ, 2004.

FREIRE, J. R. B. Da língua geral ao português: para uma história dos usos sociais das línguas amazônicas. Rio de Janeiro: UERJ - Tese de Doutorado, 2003.

GALLO, G. Marajó, a ditadura da água. 3. ed. Cachoeira do Arari: Museu do Marajó, 1997.

GALLO, P. G. Motivos ornamentais da cerâmica marajoara. 3. ed. Cachoeira do Arari - Marajó: Museu do Marajó, 2005.

GALVES, C. M. C. Ensaios sobre as gramáticas do português. Campinas: Unicamp, 2001 .

GALVES, C.; GARMES, H.; RIBEIRO, F. R. África no Brasil: Caminhos da língua portuguesa. Campinhas: Unicamp, 2009.

GIVÓN, T. Syntax: Functional Typlogical Introduction. [S.1.]: [s.n.], v. 1, 2001.

GOES, S. S. Navegantes, Bandeirantes, Diplomatas: Aspectos da descoberta do continente, da penetração do território brasileiro extra-Tordesilhas e do estabelecimento das fronteiras da Amazônia. Brasília: IPRI, 1991.

GOMES, F. D. S. A hidra e os pântanos. Mocambos, quilombos e comunidades de fugitivos no Brasil (séculos XVII e XIX). Campinas: Universidade Estadual de Campinas. Tese de Doutorado., 1997.

GOMES, F. D. S. Mocambos e quilombos: uma história do campesinato no Brasil. 1. ed. São Paulo: Claro Enigma, 2015. 
HAAN, F. The relation between modality and evidentiality. Linguistische Berichte, Hamburg, 2000.

HAAN, F. D. Typological approaches to modality. Berlim: William Frawley, 2004. HEINE, B.; KUTEVA, T. Language Contact and Grammatical Change. Cambridge: CUP, 2005.

IBGE: Salvaterra. Biblioteca IBGE. Disponivel em:

<biblioteca.ibge.gov.br/visualizacao/dtbs/para/salvaterra.pdf>. Acesso em: 27 maio 2014.

LEVINSON, S. C. Pragmática. Tradução de Luis Carlos Borges e Anibal Mari. São Paulo: Martins Fontes, 2007.

LOPES, N. Bantos, Malês e identidade negra. Rio de Janeiro: Forense, 1988.

LUCCHESI, D. O conceito de transmissão linguística irregular e o processo de formação do português do Brasil. In: RONCARATI, C.; ABRAÇADO, J. Português Brasileiro: contato linguístico, heterogeneidade e história. Rio de Janeiro: 7Letras, 2003. p. 304.

LUCCHESI, D. A diferenciação da Língua Portuguesa no Brasil e o contato entre línguas. Estudos Linguísticos Galega, Bahia, v. 4, p. 45-65, 2012.

LUCCHESI, D.; BAXTER, A.; RIBEIRO, I. O português afro-brasileiro. Bahia: EDUFBA, 2009.

MALUNGO. Coordenação das Associações das Comunidades Remanescentes de Quilombos do Pará. Disponivel em: <https://malungupara.wordpress.com/>. Acesso em: 10 março 2015.

MAPA Território Quilombola de Salvaterra. Disponivel em:

<http://image.slidesharecdn.com/aspectosdaculturaquilombola-120517094919phpapp01/95/aspectos-da-cultura-quilombola-10-1024.jpg?cb=1337266422>. Acesso em: 24 abril 2015.

MATTOS E SILVA, R. V. Sete estudos sobre o português Kamayurá. Bahia: Centro Editorial e Didático da UFBA, 1988.

MATTOS E SILVA, R. V. Ensaios para uma sócio-história do português brasileiro. São Paulo: Parábola, 2004. 
MATTOSO CÂMARA JR., J. A Alternância Portuguesa "fui : foi". Revista de

Cultura, Rio de Janeiro, v. 34, p. 98-106, 1943.

MATTOSO CAMARA, J. Estrutura da Língua Portuguesa. 33. ed. Petrópolis:

Vozes, 2001.

MATtoso CÂMARA, J. J. História e Estrutura da Língua Portuguesa. Rio de Janeiro: Padrão - Prolivro, 1975.

MATTOSO CÂMARA, J. J. Estrutura da Língua Portuguesa. 33. ed. Petrópolis: Vozes, 2001.

MAUÉS, R. H. Um aspecto da diversidade cultural do caboclo amazônico: a religião. Estudos Avançados, Belém, v. 19, n. 53, p. 259-274, 2005.

MAUÉS, R. H. Religião e medicina popular na Amazônia: etnografia de um romance. Revista Anthropológicas, Belém, v. 18 (2), n. 11, p. 153-182, 2007.

MAUÉS, R. H. O Perspectivismo indígena é somente indígena? Cosmologia, religião, medicina e pop ulações rurais na Amazônia. Dossiê - Amazônia: Sociedade e Natureza, Londrina, v. 17, n. 1, p. 33-61, jan./ju. 2012.

MESTRE Damasceno, 2013. Disponivel em: <http://terruapara.com.br/mestredamasceno/>. Acesso em: 01 maio 2015.

MULHERES Quilombolas. Comunidades de Salvaterra - PA, Campinas, p. 167-179, 1989. Disponivel em:

<http://www.cpisp.org.br/comunidades/html/i_mulheres\%20salvaterra.html>. Acesso em: 01 maio 2015.

NAEA. Quilombos do Pará - CD Rom. Belém: NAEA-UFPA \& Programa Raízes, 2005.

NARO, A.; SCHERRE, M. A concordância de número no português do Brasil: um caso típico de variação inerente. In: HORA, D. Diversidade linguística no Brasil. João Pessoa: Idéia, 1997. p. 93-114.

NARO, A.; SCHERRE, M. Origens do português brasileiro. São Paulo: Parábola Editorial, 2010.

NEVES, M. H. D. M. Gramática de Uso do Português. 2a. ed. São Paulo: UNESP, 2011. 
NOLL, V.; DIETRICH, W. O português e o tupi no Brasil. São Paulo: Contexto, 2010.

NUNES, A. C. M. No palco da cultura marajoara: identidades e saberes em mestre Damasceno. Belém: UNAMA - Dissertação de Mestrado, 2013.

OLIVEIRA, M. D. D.; PRAÇA, W. N. Para um cotejo etnolinguístico entre comunidades afro-indígenas - Jurussaca (PA) e Tremenbé (CE): primeiras aproximações. Contatos Afro-Latinos: perspectivas histórico-linguísticas. Campinas: [s.n.]. 2013. p. 2.

OLIVEIRA, M. S. D. D. et al. O conceito de português afro-indígena e a comunidade de Jurussaca. In: AVELAR, J.; ÁLVAREZ, L. Dinâmicas Afro-latinas: línguas e histórias. Stockholm: SUP-Stockolm University Press, 2015. In: Dinâmicas afro-latinas: línguas e histórias.

ORLANDI, E. P.; SOUZA, T. C. C. D. A língua imaginária e a língua fluida: dois métodos de trabalho com a linguagem. In: (ORG.), E. P. O. Política linguística na América Latina. Campinas: Pontes, 1988.

PACHECO, A. S. As Áfricas nos Marajós: visões, fugas e redes de contato. In: SCHAAN, D. P.; MARTINS, Muito Além dos Campos: Arqueologia e História na Amazônia Marajoara. Belém: GKNoronha, 2010. p. 201.

PACHECO, A. S. Encantarias Afroindígenas na Amazônia Marajoara: Narrativas, Práticas de Cura e (In)tolerâncias Religiosas. Dossiê: Biodiversidade, Política e Religião, Belo Horizonte, v. 8, n. 17, p. 88-108, abr./jun. 2010. ISSN 2175-5841. PACHECO, A. S. Astúcias da Memória: Identidades Afroindígenas no corredor da Amazônia. Revista Tucumduba, v. 2, p. 40-51, 2011.

PACHECO, A. S. Os estudos culturais em outras margens: identidades afroindígenas em "zonas de contato" amazônicas. Fênix - Revista de História e Estudos Culturais, Pará, v. 9, n. 3 , p. 1 a 19, setembro/outubro/novembro/dezembro 2012.

PALMARES, F. C. Processo de Reconhecimento de Comunidade Remanescente de Quilombo. Departamento de Proteção do Patrimônio Afro-Brasileiro. Brasília. 2011. PALMER, F. R. Mood and Modality. Cambridge: Press, Cambridge University, 2001. 
PARÁ Cultura Fauna e Flora: Dança Siriá. Disponivel em:

<http://cdpara.pa.gov.br/siria.php>. Acesso em: 01 maio 2015.

PAULA, E. D. D. Eventos da fala entre os Apyãwa (Tapirapé) na perspectiva da etnossintaxe: singularidades em textos orais e escritos. Goiânia: Universidade Federal de Goiás, v. Tese de Doutorado, 2012.

PENNA, D. S. F. Algumas palavras da língua dos Aruans. Biblioteca Digital Curt Nimuendaju. ed. Rio de Janeiro: Typ. Economica, de Machado \& C., v. 4, 1879. Archivos do Museu Nacional do Rio de Janeiro.

PEREIRA, D. O Crioulo de Cabo Verde. In: (ORGS.), I. H. F. \&. A. Introdução à Linguística Geral e Portuguesa. Lisboa: Caminho, 1996. p. 551-559.

PEREIRA, D. Crioulos de base portuguesa. História da língua portuguesa. Disponivel em: <http://cvc.instituto-camoes.pt/hlp/geografia/crioulosdebaseport.html>. Acesso em: 10 fevereiro 2016.

PESSOA DE CASTRO, Y. O português do Brasil, uma intromissão nessa história. In: GALVES, C.; GARMES, H.; RIBEIRO, F. África-Brasil: caminhos da língua portuguesa. Campinas: Unicamp, 2009. p. 175-183.

PETTER, M. Línguas Africanas no Brasil. África: Revista do Centro de Estudos Africanos, São Paulo, p. 27-28:63-69, 2006/2007.

PETTER, M. Uma hipótese explicativa do contato entre o português e as línguas africanas, São Paulo, p. 9-19, 2007. Disponivel em: <http://revistas.fflch.usp.br/papia/article/viewFile/2029/1850>. Acesso em: 10 nov. 2015.

POGGIO, R. M. Processos de Gramaticalização de Preposições do Latim ao Português: uma abordagem funcionalista. Salvador: EDUFBA, 2002.

PRAÇA, W. N. Morfossintaxe da Língua Tapirapé (Família Tupí-Guraraní). Brasília: Tese de doutorado, 2007.

PRAÇA, W. N.; TORIDO, C. Similaridades morfossintáticas do português de Siricari em cotejo com o português étnico Ãpyãwa. Revista Sociodialeto - Web, v. 6, n. 17, Novembro 2015. ISSN 2178-1486. 
REIS, J. J.; GOMES, D. S. Liberdade por um fio: história dos quilombos no Brasil. 5. ed. São Paulo: Cia das Letras, 2011.

RODRIGUES, A. D. As línguas gerais sul-americanas. Repositório Institucional Universidade de Brasília, 1996. Disponivel em: <http://repositorio.unb.br/>. Acesso em: 20 março 2016.

RONCARATI, CLAUDIA; ABRAÇADO, JUSSARA. Português Brasileiro: contato linguistico, heterogeneidade e história. Rio de Janeiro: 7 Letras, 2003. 304 p.

SALLES, V. O negro no Pará: sob o regime da escravidão. Rio de Janeiro: Fundação Getúlio Vargas e Universidade Federal do Pará, 1971. 336 p.

SCHERRE, M. M. P. Aspectos da concordância de número no português do Brasil.

Revista Internacional de Língua Portuguesa (RILP) - Norma e Variação do

Português, Rio de Janeiro, p. 12:37-49, dezembro 1994.

SCHWARTZ, S. B. Mocambos, quilombos e Palmares: a resistência escrava no Brasil colonial. São Paulo: IPE-USP, v. 17 , 1987. 69-81 p.

SILVA, I. A. D. C. E. Corografia Paraense, ou Descrição Física, Histórica, e Políitica da Província do Gram-Pará. Bahia: Typografia do Diário, v. Seção III. Comarca da Ilha Grande de Joannes ou Marajó, 1833.

SILVA, J. F. C. D. O português afro-indígena de Jurussaca/PA: revisitando a descrição do sistema pronominal pessoal da comunidade a partir da textualidade. São Paulo: USP-Tese de Doutorado, 2014.

SILVA, J. R. D. Evolução do estudo das língua indígenas no Brasil. Rio de Janeiro: Gráfica Laemmert Ltda, 1965.

SILVA, R. V. D. M. E. Uma interpretação para a generalizada difusão da língua portuguesa em território brasileiro. Gragoatá, Niterói, v. 9, p. 11-27, 2000.

SIMPSON, P. L. Gramática da Língua brasileira - Brasílica, Tupi ou Nheêngatu. 5. ed. Rio de Janeiro: [s.n.], 1955.

STEWARD, J. H. Handbook of South American Indians. Biblioteca Digital Curt Nimuendaju. ed. Washington: United States Government Printing Office, v. 3, 1948. 
VERÍSSIMO, J. Biblioteca Digital Curt Nimuendaju. As populações indigenas e mestiças da Amazonia, Rio de Janeiro, 1887. Disponivel em:

<http://biblio.etnolinguistica.org>. Acesso em: 04 agosto 2015.

VIANNA, A. Os contemplados. Nota ao catálogo anterior. In: Annaes da

Bibliotheca e Archivo Publico do Pará. Belém: Typ. e Encardenação do Instituto Lauro Sodré, v. Tomo III, 1904. Cap. 2, p. 154-159.

VIEIRA, P. A. Sermam da primeira dominga do advento - quinta parte. Google livros, Lisboa, 1689. Disponivel em: <https://books.google.com.br>. Acesso em: 12 fevereiro 2016.

VOGT, C.; FRY, P. Cafundó: A África no Brasil. São Paulo: Companhia das Letras, 1996. 
$\underline{\text { Anexo 1- Comunidade Siricari }}$
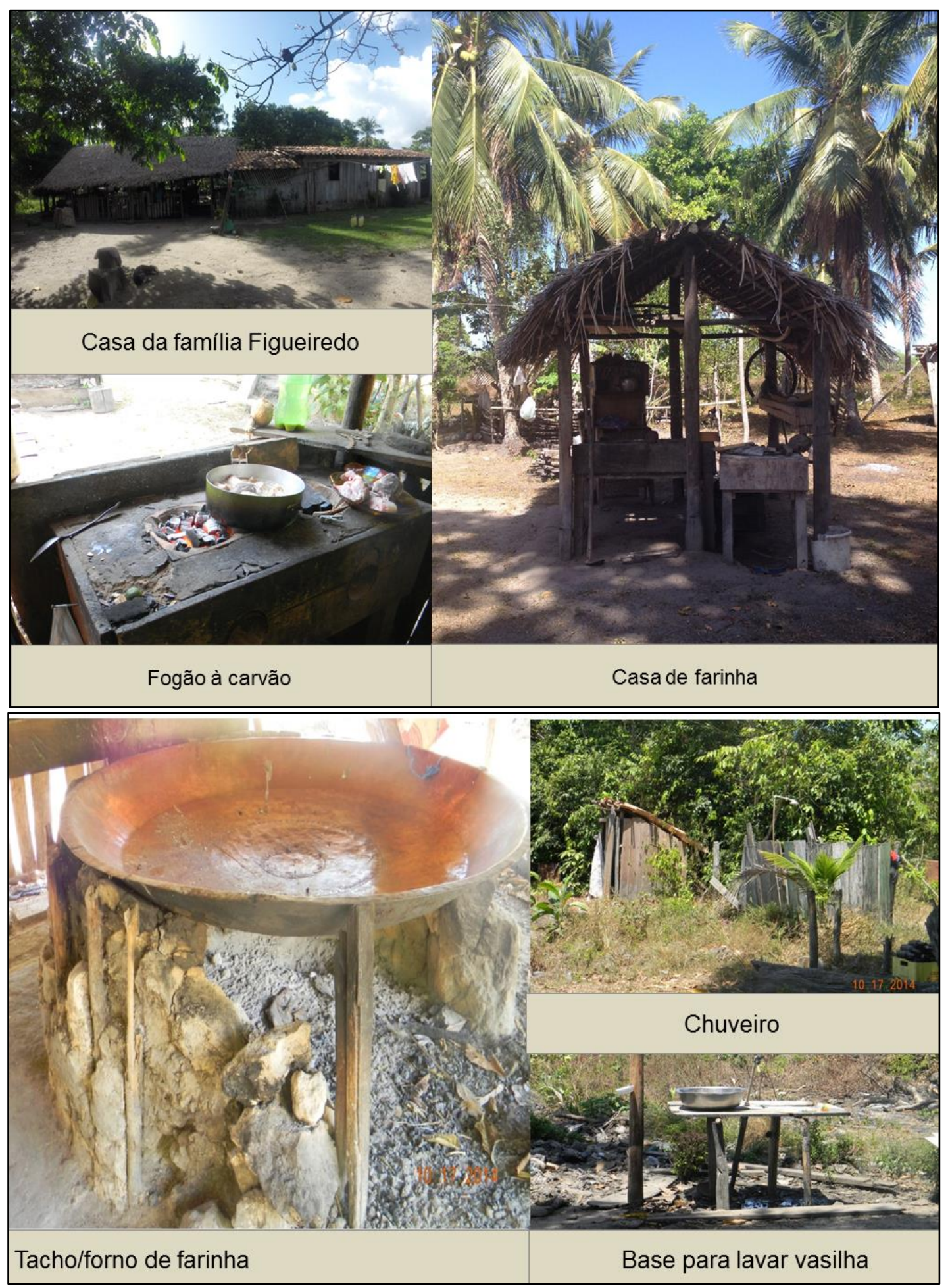


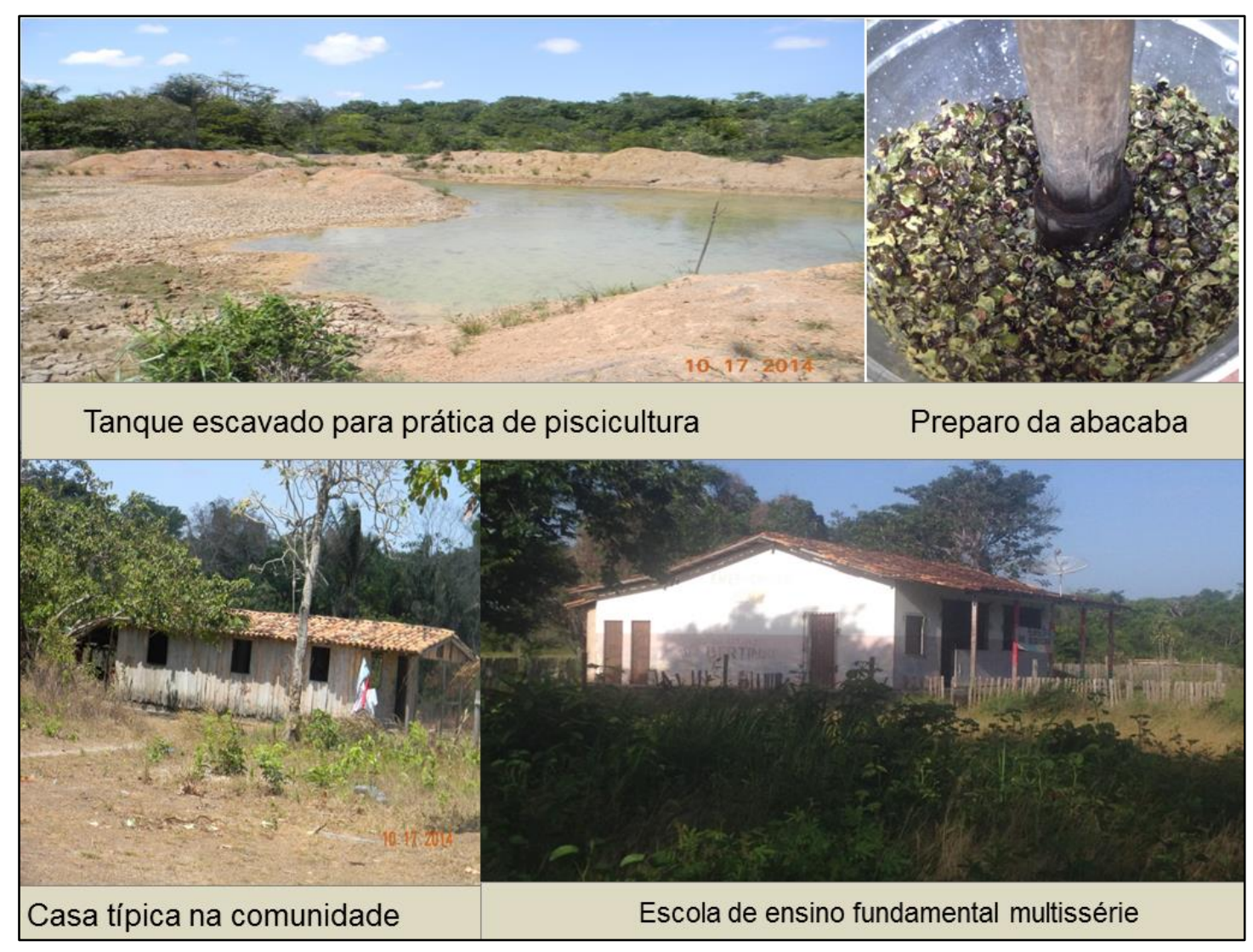

Anexo 2- Cultura

Peça de cachimbo encontrada enterrada na comunidade
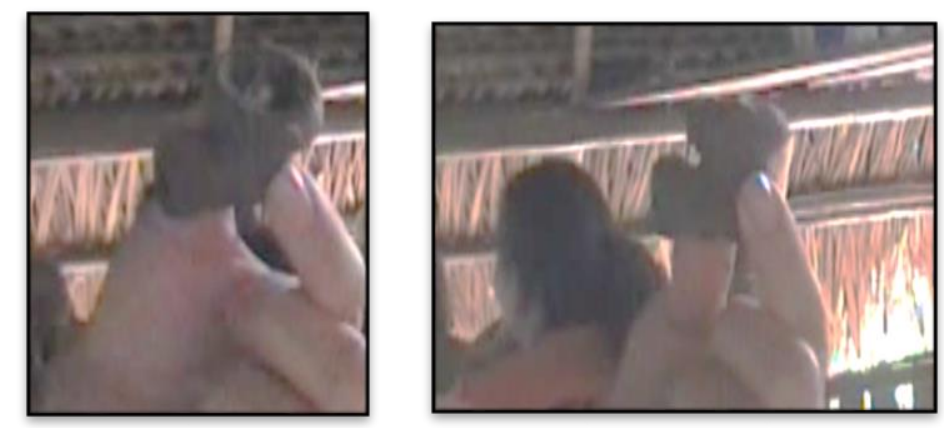

Mestre Damasceno

Fonte: blogspot.com/cinema-paraense-no-verao-de-salvaterra.html/

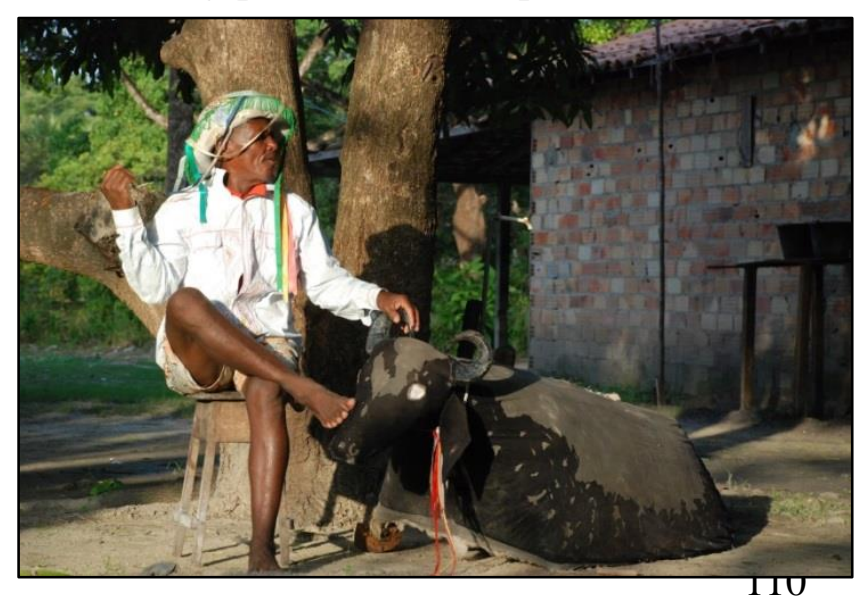


Anexo 3- Histórias contadas pelos moradores da comunidade Siricari

\section{Uiara}

(SR-10) É... eu acho que sim, num... e é assim, né, e é meio... aqui antigamente era meio visagento, aparecia umas iara, carregava as pessoa meu pai contava que um dia eles tavam, era uma casa mais pra ali, essa casa grande mesmo dele era uma casa grande inteira, aquela assim de barro, né, era grande lá que eles faziam as festa deles lá, lá que tinha laranjal, cocalque (?) aí, onde é que uma menina fazendo uma criança dormi, né, sete hora da noite, cantando na sala, se embalando, né, a diz que viram ela calá, né, aí disse "a fulana tá dormindo, dormiu" [ININT] escutaram o grito dela no mato, aí que foi diz que ela tava numa rebolada de espinho e pra tirá essa menina de lá diz foi uma luta.

\section{Galo de ouro}

(SR-08) Olha, só a minha mãe diz que qui inda tinha, né, que a bisavó dela diz que era... inda índia, né, ela é... que quando começô aqui a guerra da cabanage, né foi que eles interraro as coisa e correro, se escondero, ainda a vó, non, era a mãe do finado Lili, diz que se meteu num baú grande, que antigamente usava aqueles bauzon, né, agora cobria de ropa diz que assim que ela fez aí quando foro embora com o negócio da guerra, foro varando aí pelo Rosário, foro terminá lá pra Joanes, foi ali em Monsará tudo por lá eles foro passando, em Monsarás tem até um poço no meio da rua diz que hora de meio dia a gente olha lá diz que enxerga um galo, né, diz que um galo de oro lá, mas isso sabe lá quem é que enxerga, né?

\section{Poço seco}

(SR-08) Eles, os antigo jogaro tudo, enterraro, depois com o negócio de roça, né, foi achando e tinha um poço lá, é... a tia F. diz assim "sabe lá o que num tem nesse poço, sabe inda lá que tá o oro. 
(SR-04) Já nem parece mais, né, tia H.?

(SR-08) É, já tá quase assim.

(SR-04) Já tá tapando, já. Eu já cheguei a vê ele.

\section{Sinal}

(SR-08) Enterraro oro, eu sei que oqui nesse manguerá fazia até visage, num era tio? Ainda faz, o meu sogro, o irmão do meu sogro eie saiu pra espiá cutia, era tio dele, avô dele, finado Luciano, aí diz quando ele viu aquela luz veio, aquela luzinha tamanha manhã cedo, aí diz que aí ele ficô até esmorecido, aí a luz veio, veio, ficô acesa aí ele desceu e veio convidá o irmão que só podia sê dinhero aí o finado Lili, como era mais inteligente, né, que ... aí diz que ele disse "tu assinalaste, Luciano?" "não" "ah... então é pra ti, rapaz, nós num vamo achá", aí... "non, eu sei aonde é" aí foro pra lá, ali, cavaro, cavaro, cavaro, cavaro tanto, cadê? Num acharo nada. Tem que sê pra quela pessoa é... é difícil que otro num...

\section{Anexo 4- Disposição das casas na comunidade Mangueiras}

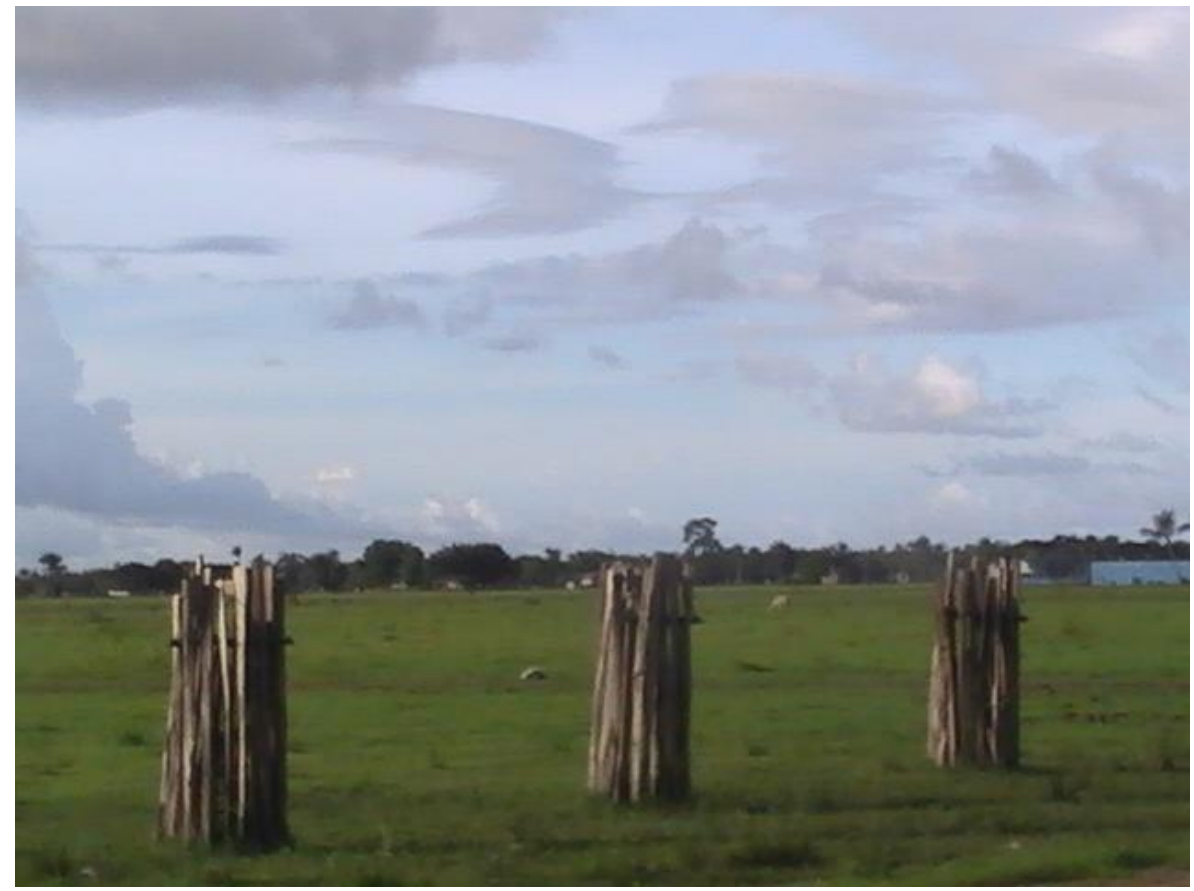

Disposição circular das casas na comunidade Mangueiras 